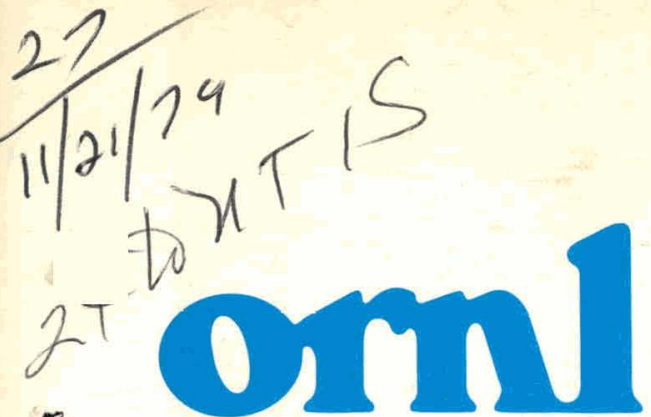

OAK

RIDGE

NATIONAL

LABORATORY

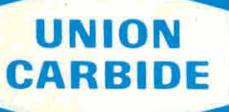

\author{
Input-Output Analysis of \\ Various Elements of an \\ Energy-Agro-Waste Complex
}

OPERATED BY

UNION CARBIDE CORPORATION FOR THE UNITED STATES DEPARTMENT OF ENERGY 


\section{DISCLAIMER}

This report was prepared as an account of work sponsored by an agency of the United States Government. Neither the United States Government nor any agency Thereof, nor any of their employees, makes any warranty, express or implied, or assumes any legal liability or responsibility for the accuracy, completeness, or usefulness of any information, apparatus, product, or process disclosed, or represents that its use would not infringe privately owned rights. Reference herein to any specific commercial product, process, or service by trade name, trademark, manufacturer, or otherwise does not necessarily constitute or imply its endorsement, recommendation, or favoring by the United States Government or any agency thereof. The views and opinions of authors expressed herein do not necessarily state or reflect those of the United States Government or any agency thereof. 


\section{DISCLAIMER}

Portions of this document may be illegible in electronic image products. Images are produced from the best available original document. 


\section{Printed in the United States of America. Available from National Technical Information Service \\ U.S. Department of Commerce \\ 5285 Port Royal Road, Springfield, Virginia 22161 NTIS price codes-Printed Copy: A08 Microfiche A01}

This report was prepared as an account of work sponsored by an agency of the United States Government. Neither the United States nor any agency thereof, nor any of their employees, makes any warranty, expressed or implied, or assumes any legal liability or responsibility for any third party's use or the results of such use of any information, apparatus, product or process disclosed in this report, or represents that its use by such third party would not infringe privately owned rights. 
Contract No. W-7405-eng-26

Subcontract No. ORNL-11Y-13549V

\title{
INPUT-OUTPUT ANALYSIS OF VARIOUS ELEMENTS \\ OF AN ENERGY-AGRO-WASTE COMPLEX
}

Prepared by

Cal Recovery Systems, Inc. Richmond, California 94804

\author{
for \\ Department of Energy \\ Washington, D.C. 20545
}

Date Published: November 1979

OAK RIDGE NATIONAL LABORATORY

Oak Ridge, Tennessee 37830

operated by

UNION CARBIDE CORPORATION

for the

DEPARTMENT OF ENERGY

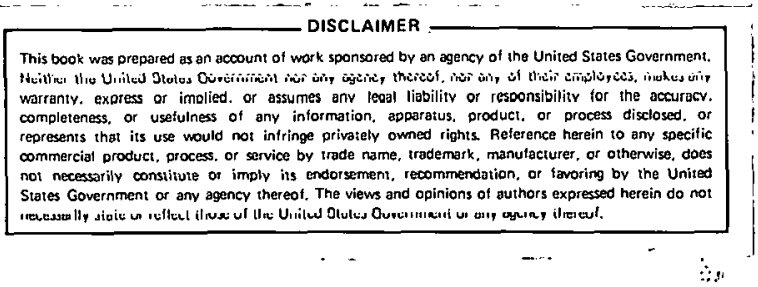


THIS PAGE

\section{WAS INTENTIONALLY}

LEFT BLANK 
FOREWORD ...................... . . v v

ABSTRACT ................................... vii

LIST OF FIGURES . . . . . . . . . . . . . . . . . . ix

LIST OF TABLES . . . . . . . . . . . . . . . . . xi

ACKNOWLEDGEMENTS .................................... xi

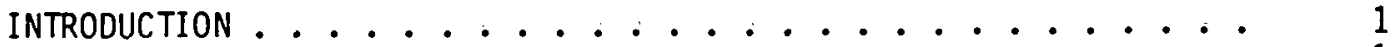

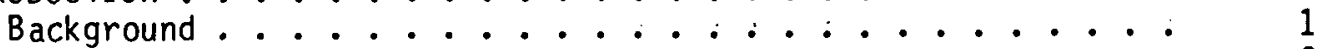

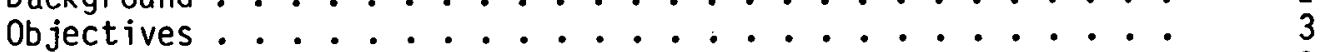

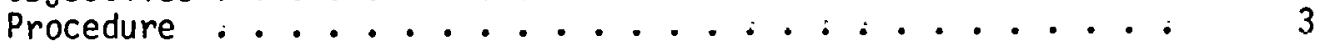

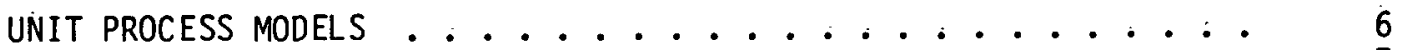

Un it Processes for Animal Production . . . . . . . . 7

Chicken Production.............. 10

Beef Production ............... 10

Pork Production ................. . . . 12

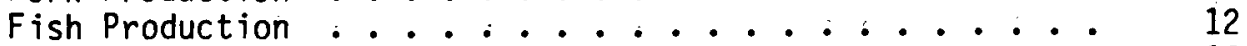

Catfish Production............. . . 16

Tilapia Production .............. 16

Trout Production .............. . . 18

Un it Processes for Plant Production ........... 21

Greenhouse Plant Production ........... 21

Open Field Plant Production ............ 25

Water Hyac inth Production ............ 31

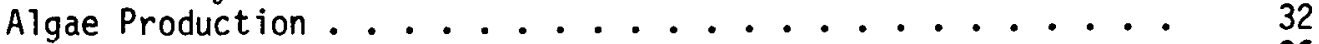

Anaerobic Digestion ................... . . 36

Sewage Treatment Processes.............. 36

POTENTIAL INTEGRATED SYSTEMS ................ . . 42

Refeeding of Wastes ............... 42

Chicken-Cattle-Algae-Digester Complex ......... . . 45

Fish-Chicken-Cattle-Algae-Hyac inth-Digester Complex .... 47

Fish-Chicken-Cattle-Swine-Algae-Hyac inth Complex . . . . . 49

Greenhou se-Open Field-Chicken-Cattle-Digester Complex .... 51

Open Field-Cattle-Ch 1cken-Digester Complex ........ 53

Tree Farm-Cattle-Digester Complex . . . . . . . . 55

Greenhou se-Fish-Digester-Recreational Water Complex . . . . 57

Sewage-Hyacinth-Digester-Swine-Composting-Open Field Complex . 59

Hyac inth-Cattle Complex ............. 59

Fish-Open Field Complex .............. 62

Summary Statements on the Potential Complexes ........ 64

MASS BALANCE ANALYSIS OF INTEGRATED COMPLEXES . . . . . . . 65

Chick en-Digester-Algae-Ti lapia Complex .......... 66

Greenhou se-Cattle-Digester-Open Field Complex ...... 68 
TABLE OF CONTENTS (continued)

Chicken-Catt le-Digester-Open Field Complex . . . . . . 70

Sewage-Digester-Hyac inth-Swine-Open Field Complex . . . . 72

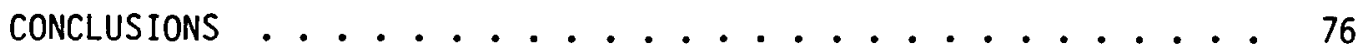

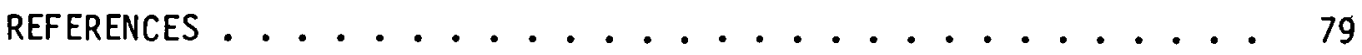

APPENDIX A ............................... 85

APPENDIX B ................................... 103

APPENDIX C . . . . . . . . . . . . . . . . 113

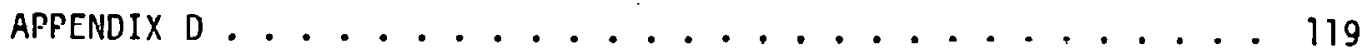

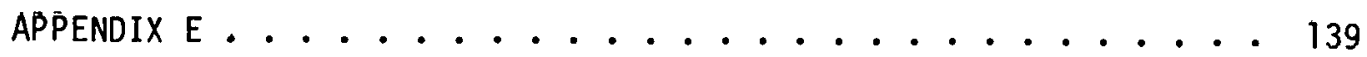


It has been recognized that, because of power cycle operating conditions, nuclear power plants reject more waste heat per unit of electricity produced than comparable fossil stations. Because the waste heat problem is more severe for nuclear power stations, research in the area of beneficial uses of waste heat has been sponsored for a number of years by the Advanced Nuclear Systems and Projects Division of DOE (formerly Nuclear Research and Applications Division of ERDA).

These studies have considered various uses for power plant reject heat and have centered on agricultural applications. Some of this agricultural work has been carried out in a cooperative program with the Tennessee Valley Authority (TVA). This work is continuing with a 0.5 acre demonstration greenhouse being constructed by TVA at the Browns Ferry Nuclear Station. This greenhouse is based on a DOE-supplied design, and a combined DOE-TVA report concerning this project will be issued after the greenhouse has been in operation for a growing season.

During the course of the beneficial uses investigations, it became evident that multiple-use facilities (i.e. incorporating more than one utilization technology) would be extremely important if waste heat utilization is to be implemented on a significant scale. It was also clear. that the potential existed for a number of mass as well as energy interactions between, the individual subsystems of such a complex. A few existing studies had examined the relative sizes of the subsystems by merely accounting for their energy consumption. However, no existing studies sought to analyze a highly integrated facility. This study was, 
therefore, initiated to provide a comprehensive data base and develop a methodology for designing and analyzing highly integrated waste heat ut ilization complexes. As a first step, the analysis concentrated on possible mass interactions between components of the complex.

Thits work was carried out under contract with Oak Ridge National Laboratory, Contract No. 11Y-13549V.

This study was conducted under the direction of Or. Luis F. Diaz and Dr. Clarence G. Golueke. Data collection and analys is were performed by Mr. Stephen B Tlumenkranz and Or. John C. Glaub. Drs. Diaz, Golueke, and Glaub are the principal authors of this report. The manuscript was typed and edited by Mrs. Linda. Eggerth and Mrs. Janice Hirshfield: The Project officer was Dr. Mitchell 0lszewski. 
The mass input and output streams of various agricultural and waste treatment processes were quantified and models developed to serve in the engineering analysis of potential waste heat utilization schemes. The unit process models can be integrated into energy-agro-waste complexes, in which waste heat from power plants is used by certain processes and the wastes of some processes are used as inputs to others. The models provide a means of determining the sizing of subsystems, the compatibility of subsystems, and the overall feasibility of an integrated complex. len potential complexes were qualitatively discussed and the considerations involved in forming such complexes explained. A mass balance analysis was performed on four integrated complexes demonstrating the engineering value of the analytical models developed. 
THIS PAGE

WAS INTENTIONALLY

\section{LEFT BLANK}




\section{LIST OF FIGURES}

1 Generalized diagram of typical input and outputs of a unit process................. 8

2 Mass balance diagram for chicken production ......... 11

3 Mass balance diagram for beef production ......... 13

4 Mass balance diagram for pork production . . . . . . . 14

5 Mass balance diagram for catfish production . . . . . . . 17

6 Diagram of inputs and outputs for a tilapia-algae-pond . . . 19

7 Mass balance diagram for tilapla production ........ 20

8 Generalized diagram of a greenhouse un it process . . . . . 23

9 Mass balance diagram of a tomato greenhouse unit process . . 24

10 NPK mass balance diagram for rice production ....... 26

11 NPK mass balance diagram for corn production . . . . . . 27

12 NPK mass balance diagram for sorghum production . . . . . 28

13 NPK mass balance diagram for wheat production . . . . . . 29

14 NPK mass balance diagram for oat production . . . . . . . 30

15 Mass balance diagram for water hyacinth production ..... 33

16 Mass balance diagram for algae production ......... 35

17 Mass balance diagram for anaerobic digestion process . . . . 37

18 Compositional balance diagram of the combined effects of primary and secondary sewage treatment .......... 39

19 Mass balance diagram of the combined effects of primary and secondary sewage treatment ................... 40

20 Flow pattern of suspended solids in a sewage treatment plant . 41

21 Diagramatic sketch showing mass and energy interrelationships of a Chicken-Catt le-Algae-Digester Complex ....... 46 46

22 Diagrammatic sketch showing mass and energy interrelationships of a Fish-Chicken-Cattle-Algae-Hyacinth-Digester Complex .. . 48 


\section{LIST OF FIGURES (continued)}

23 Diagrammatic sketch showing mass and energy interrelationships of a Fish-Chicken-Cattle-Swine-Algae-Hyacinth Complex . . . 50

24 Diagrammatic sketch showing mass and energy interrelationships of a Greenhou se-Open Field-Chicken-Cattle-Digester Complex . . 52

25 Diagrammatic sketch showing mass and energy interrelationships of an Open Field-Cattle-Chicken-Digester Complex ......

26 Diagrammatic sketch showing mass and energy interrelationships of a Tree Farm-Cattle-Digeșter Complex ........... 56

27 Diagrammatic sketch showing mass and energy interrelationships of a Greenhouse-Fish-0igester-Kecreational Water Complex. . .

28 Diagrammatic sketch showing mass and energy interrelatitinnships of a Sewage-Hyacinth-Digester-Swine-Composting-Open Field

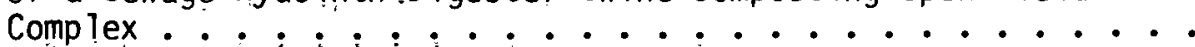

29 Diagramatic sketch showing mass and energy interrelationships of a Hyac inth-Catt le-Complex .............

30 Diagramatic sketch showing mass and energy interrelationships

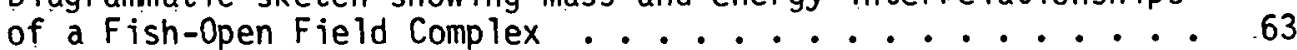

A1 Terminology pertaining to energy in animal nutrition . . . . 86

D1 Block diagram model of a Chicken-Digester-Algae-Tilapia Complex 119

D2 Block diagram model of a Greenhouse-Cattle-Digester-Open Field

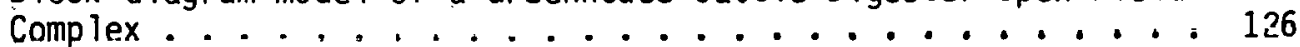

D3 Block diagram model of a Chicken-Cattle-Digester-Open Field

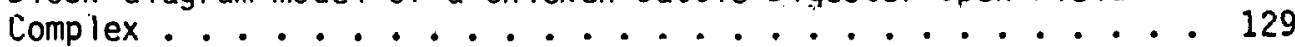

D4 Block diagram model of a Sewage-Digester-Hyac inth-Swine-Open

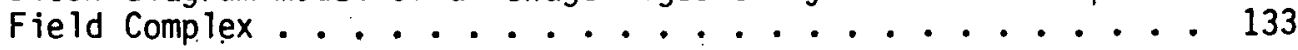

E1 Integration of mass balances in the Chicken-Digester-Algae-

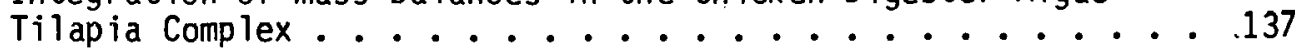

E2 Integration of mass balances in the Greenhouse-Cattle-Digester-

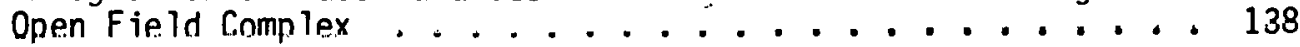

E3 Integration of mass balances in the Chicken-Cattle-DigesterOpen Field Complex .............. 139

E4 Integration of mass balances in the Sewage-Digester-Hyacinth Swine-Open Field Complex ............. 140 


\section{LIST OF TABLES}

1 Procedure for Determination of Input and Output Data for

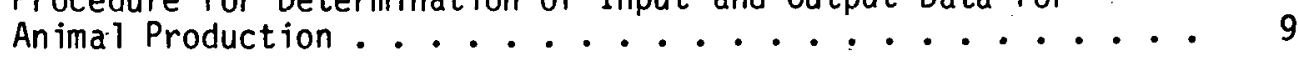

2 Potential Roles of Unit Processes in Integrated Complexes . . 43

Al Input Data Regarding Chicken Production . . . . . . 87

A2 Output Data Regarding Chicken Production . . . . . . . 88

A3 Input Data Regarding Beef Production .......... 90

A4 Output Data Regarding Beef Production ........... 91

A5 Input Data Regarding Pork Production ........... 93

A6 Output Data Regarding Pork Production . . . . . . . . 94

A7 Input Data Regarding Catfish Production . . . . . . . . 96

A8 Output Data Regarding Catfish Production ... . . . . . 97

A9 Input Data Regarding Tilapia Production . . . . . . . 98

A10 Output Data Regarding Tilapia Production . . . . . . . 100

Al1 Input Data Regarding Trout Production . . . . . . . . 101

A12 Output Data Regarding Trout Production . . . . . . . . 102

B1 Data Used in the Mass Balance for a Tomato Greenhouse Unit 106

B2 Collection of Tomato Yields Reported in the Literature . . . 107

B3 Estimated Heating Requirements for Greenhouse Operation . . . 108

B4 NPK Content of Grains and Principal Forage Crops ....... 109

B5 Growth and NPK Uptake of Sorghum, Corn and Hay . . . . . 110

B6 Water Hyac inth Chemical Content . . . . . . . . . . 111

C1 Composition of Raw (Primary) and Treated (Secondary) Sewage 113

C2 Composition of Raw (Primary) and Activated and Digested Sludges 114

C3 Primary and Secondary Sewage Treatment Removal Efficiencies . . 115

C4 Data Regarding Algae Production . . . . . . . . . . 116 


\section{LIST OF TABLES (continued)}

D1 Transfer Functions for the Chicken-Digester-Algae-Tilapia

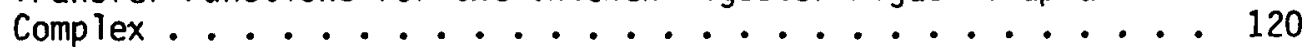

D2 Throughput Constants for the Chicken-Digester-Algae-Tilapia

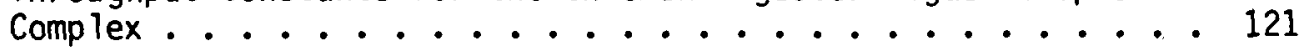

D3 Transfer Functions for the Greenhouse-Cattle-Digester-Open

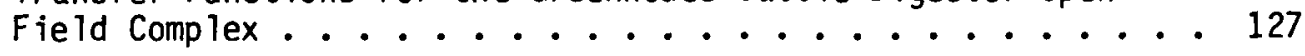

D4 Transfer Functions for the Chicken-Cattle-Digester-Open Field

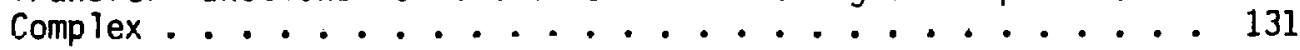

05 Transter runctions for the Sewage-Digester-Hyac inth-Swine

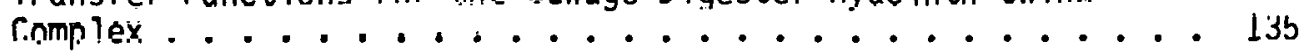




\section{ACKNOWLEDGEMENTS}

The authors would like to thank all of the ir colleagues who were kind enoigh to supply the research team with invaluable information. In particular, we would like to thank Dr. Larry Boersma (Oregon State University), Dr. George Briggs (University of California, Berkeley); Mr. Carl Madewe 11 (TVA National Fertilizer Development Center), and Mr. Robert Stickney (Texas A\&M). 


\section{INTRODUCTIUN}

\section{Background}

The growing urgency of the conservation of materials and energy provides the motivation and underlying direction for making an in-depth examination of the means traditionally used in the supply of the nation's food, energy, and services. In a simplistic but functionally descriptive sense, the population center or community requires energy, food, and various goods; and as a result of these produces a host of wastes in the form of solids, liquids, gases, and energy (principally as heat). Currently, the needs are supplied by individual, usually self-contained entities. The majority of these entities require primary ("virgin") materials and generate wastes and pollutants in the course of producing their products or providing their service. Systems have been identitied, however, in which waste heat from a power plant can be used in concert with other "waste" streams to produce valuable products. The use of secondary sewage effluent in a waste heat aquaculture system is an example of the food production capability that can be realized when waste heat is combined with one or more organic waste streams. Using waste heat to enhance methane production from sewage sludge digesters is but one example of the energy production possibilities when such waste streams are combined.

The concept of the combined utilization of waste heat and of the plant nutrients in wastes is not a novel one. It was in fact discussed as early as 1956. As interest in the subject developed, the realization 
came to many researchers that the most efficient approach to the combined utilization would be one that included a diversity in the nature of the constituent unit processes, so that the variety and amount of wastes capable of being used would be magnified.

Thus far, the majority of activity in modeling energy-agro-waste systems has been concentrated on the analysis of condenser cooling water utilization systems. The concentration stemmed from the fact that the input-output characteristics of the thermal elements are fairly well defined, whereas the nonthermal elements in the system either have not been defined or are only beginning to be characterized.

The proper identification of the input-output characteristics of the eneray-agro-waste complex subsystems would make it possible to: 1. further develop and quantify predictive techniques that are of use in determining the compatibility of various waste processing and low-grade heat utilization systems from a material and energy resource viewpoint; 2. provide quantitative insights into the various aspects of siting goods and service and energy production facilities; and 3. allow for the planning of possibilities for retrofitting existing facilities with recovered materials and energy forms.

Thus far, few attempts have been made to arrive at a suitable relative sizing of the operations that would be used. In the present study, the establishment of the sizing is advanced to a point at which hoperully a choice of relative sizing and estimate of feasibility can be made on a more rigorously quantitative bas is than could be done heretofore. The advance was made in part by establishing as tar as possible the pathways of the primary nutrients, namely, nitrogen, phosphorus, and potassium $(N, \mu, K)$. 


\section{Objectives}

The objectives of this study were to define and catalog the inputnutput streams of major subsystems that could be included in an integrated eneray-agro-waste complex and to develop models of candidate complexes. The objectives also included the identification of techniques to process waste streams into energy or product forms compatible with the various components of a complex. Thus, a primary purpose of the study was to explore physical possibilities of integrating various systems for optimizing energy and waste utilization. In so doing, the waste systems and processing techniques that were considered were those compatible with various techniques for the utilization of power plant waste heat that could be included as an input in a complex (i.e., organic wastes and biological treatment).

\section{Procedure}

Subsystems that had potential for inclusion in energy-agro-waste complexes were selected, and the ir input-output streams were identified and characterized. The characterization of input-output streams required intormation crossing the lines of many branches of science. Thus, an extensive multi-disciplinary literature search was conducted and quantitative information gathered on the various energy, agricultural, biological and waste processes under consideration. This literature search was conducted in several stages, with increasing extensiveness as the project progressed. The nature of the data which included wide ranges of reported values, as we 11 as a lack of data on certain parameters, directed the course of these efforts. Private communication with researchers around the country was frequently required. 
Analysis of the data was also influenced by the nature of the data, and consequently several assumptions had to be made. These were as follows: 1. Waste heat is available in sufficient quantity and is transferable at a price that permits all processes to operate at optimum temperature. 2. It is valid to use average values for variables in many processes despite seasonal, geographical, life cycle, and observable differences. 3. Biological processes can be adequately characterized by only a few of their grossest inputs and outputs. 4. Published data can be reasonably adjusted with in limits of reported ranges to reconcile inputs and outputs without significantly affecting the validity of the overall model. 5. All processes are at steady-state conditions, and therefore for any given process, input and output. should agree.

Early in the study it became apparent that total solids, nitrogen, phosphorus, and potassium should be accounted for in all calculations, i.e. whenever it was possible to do so. Although other elements, such as calcium, magnesium, and sulfur may occur in significant quantitites, they are less likely to be limiting. In the present study it is assumed that all required trace elements are present, either by way of the input wastes or through maintenance additions. Where the inclusion of a water balance was essential, one was made.

The subsystems were first analyzed as unit processes and their mass and energy inputs and outputs identified accordingly. Applying block diagrams (from control theory) to these unit processes served as a convenient means of both expressing and analyzing the input.s and nut.put.s. Limitations in data for certain parameters were also exposed, although with a combination of parameters most gaps in the data can be abridged. 
After the unit processes were developed, they were integrated into complexes accounting for the magnitudes of the compatible mass and energy flows. The integrated complexes were then analyzed to determine their utility in estimating relative sizes and feasibility. 
UKIT PROCESS MODELS

Various unit processes were selected that would lend themselves to a variety of integrated energy-agro-waste complexes. They were chicken rearing, cattle rearing, swine rearing, aquaculture (fish and algae), crop production (greenhouse and open field), wastewater treatment, and anaerobic digestion (methane production). The criteria used in their selection were their having been demonstrated technically feasible and their being either actually or potentially economically teasible.

A first step in characterizing a unit process is to identity inputs to and outputs from the system. Having identified the input-outputs, the next step is to quantity them, so as to be able to arrive at mass and energy balances. Typical inputs are: 1, ragdiated and convertern heat. enerq.y applied to maintain a Hesired temperature leve 1 ; 2 . clcctrical and mechanical energy; 3 . nutrients (etther in the form nt waste or of a primary material and in a usable form); 4. drinking water and process water; and 5. oxygen and carbon dioxide. Typical nutputs are: 1. heat loss (conductive-convective, evapnrative, radiated); 2 . water loss (throughput, evaporated, transpiration (leafy plants, blowdown); 3 . waste solids (vegetation slash, manure, slaughterhouse wastes, etc.); 4. dissolved sol1ds (BOO, CUU, salts); 5. gases $\left(\mathrm{O}_{2}, \mathrm{CH}_{4}, \mathrm{CO}_{2}, \mathrm{~N}\right)$; and 6 . food products (amount/area or volume).

Among items not mentioned in the preceding paragraph, but which would require attention with certain unit processes are: 1. optimal temperature; 
2. stock or grnwth density; 3. length of growth-harvest-restock cycle; and 4. feen-to-growth and waste-to-food ratios.

In tarilitate the collection of data on the various inputs and outputs and making mass balances, a model of a unit process is an important first step. The model serves as a guide in selecting representative or reasonable values from a reported range of values and for interrelating the collection of input-outputs. It also provides a guide for the collection of data. To make valid mass balances and to develop a comprehensive model, it is necessary to have some unit of process volume to which each input and output could be related. Such a unit could be expressed as per animal, per areal unit, or per heat dissipation unit.

A useful generalized diagram showing an arrangement of inputs and outputs is presented in figure 1. Each input is expressed in terms of mass $\left(M_{i 1}, M_{i 2}\right.$, etc.) and of energy $\left(E_{i\rceil}, E_{i 2}\right.$, etc.). Correspondingly, each output is expressed in terms of mass $\left(M_{01}, M_{02}\right.$, etc.! and of energy $\left(E_{01}, E_{02}\right.$, etc. $)$. Mass balances are expressed as $\Sigma M_{i}=\Sigma M_{0}$, and energy balances as $\Sigma E_{j}=\Sigma E_{0}$. Un-site grain and food processing are assumed tor certain cases, such that wastes and crops may be available as inputs to other processes.

\section{Unit Processes for Anımail Production}

For the unit processes pertaining to animal production (poultry, cattle, swine, and fish), a procedure was established with which it was possible to reconcile or to rationally se lect values from the reported data, especially in those instances in which a wide range of values is given. The procerure is outlined in Table I. The statements in the lable are based on the usual manner of tabulating nutritional information. Tables 


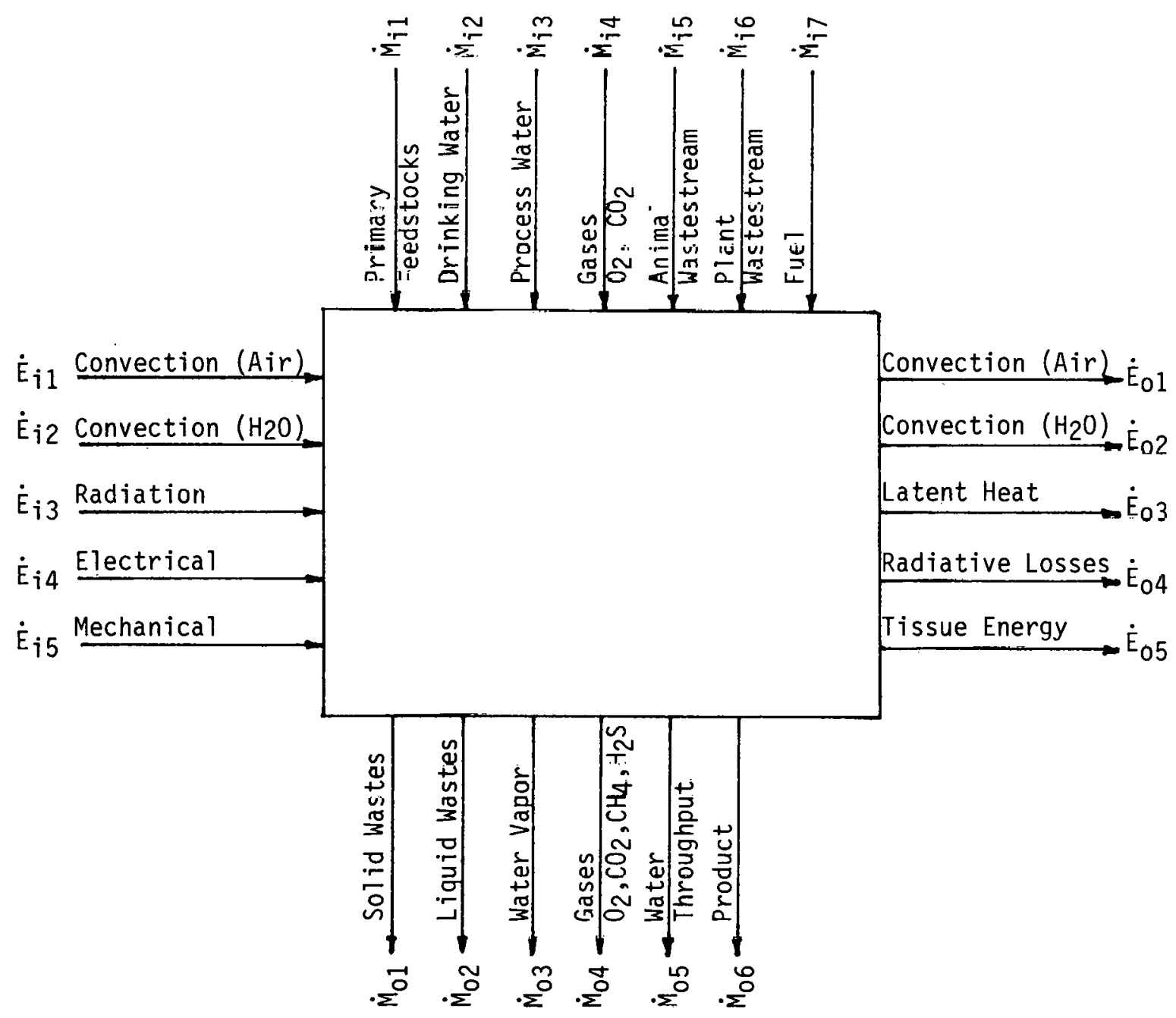

Figure 1. Generalized diagram of typical inputs and outputs of a unit process. 
Table 1

Procedure for Vetermination of Input and

Output Data for Animal Production

1. Find final weight and life span. These data will be subsequently used to determine lifetime average values for various parameters.

2. Find feed conversion ratio.

3. Find daily consumption of feed.

4. Characterize solid fraction of feed and metabolizable energy content of feed.

5. Find total metabolizable energy content in feed.

6. Find water intake.

7. Find tissue storage (weight increase) per day.

8. Characterize solid and liquid fractions of tissue.

9. Find energy content of tissue and determine energy stored per day.

10. Determine $\mathrm{O}_{2}$ consumption and $\mathrm{CO}_{2}$ production.

11. Find solid waste production per day.

12. Characterize waste composition.

13. Perform mass balame on solids.

14. Find water losses by various processes.

15. Perform mass balance on water.

16. Find heat losses.

17. Find environmental requirements. 
containing the values for the input and output parameters of various unit processes are located in Appendix A.

\section{CHICKEN PRODUCTION}

The first of the animal groups for which mass balances were made was the chicken. Chicken raising, whether it be for egg or for meat production, has been developed to become a very systematic process geared to a factory-style operation. Thus, relatively sound data are available on optimum temperatures, on the temperature dependence of latent vs. sensible heat loss, and on defined feed, manure, and water characteristics. A representative mass balance diagram for the mass production of chickens is given in Figure 2. In developing the model, averages were made for an age-distributed flock of broilers that mature (in 75 days, average) at $1.36 \mathrm{~kg}$ ( $3 \mathrm{lbs}$ ) per bird, and have a feed conversion ratio of 2.6:1 on feed that has an energy content of $12.6 \mathrm{MJ} / \mathrm{kg}$. The values in Figure 2 apply to an operation maintaining the temperature in the chicken house at $25^{\circ} \mathrm{C}$. The body temperature of the individual birds was $41^{\circ}$ C. Data from which the values given in the figures were derived are presented in Tables $A 1$ and $A$. I lable Al deals with input amounts and rates into the subsystem, while Table A2 lists outputs. The data in the two tables confirm the statement made in the previous section concerning the wide range of values reported in the literature on animal production.

\section{BEEF PŔODUCTION}

As with chicken production, data pertaining to steer production are abundant and quite reliable. Another similarity is in the concentration of the animals in confined quarters during a part of their lifespan (steers) or during the entire lifespan (chickens). In prartice, feeder 


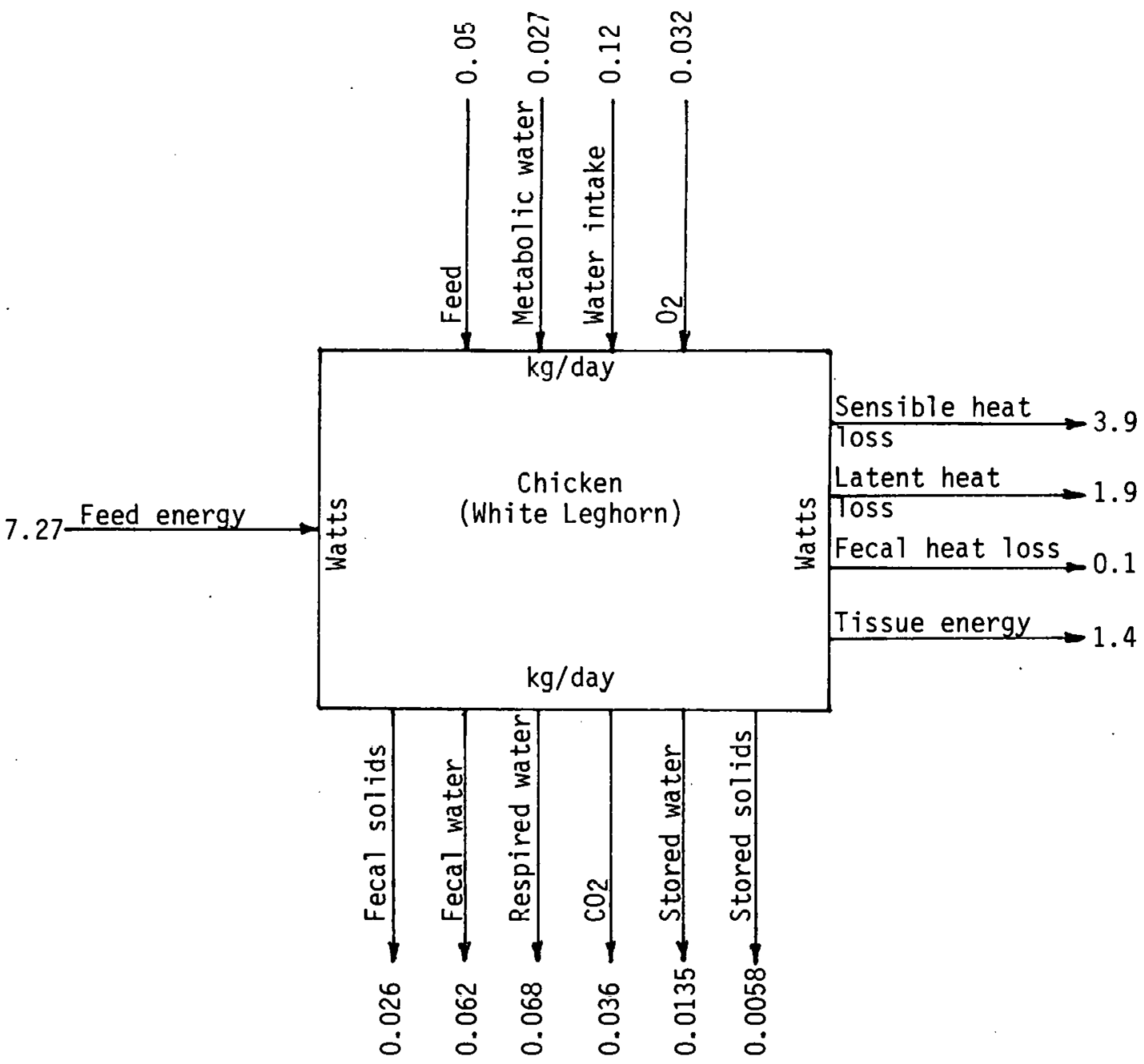

Figure 2. Mass balance diagram for chlcken production. 
cattle typically are brought to feedlots when they attain a weight of 340 $\mathrm{kg}(750 \mathrm{lbs})$. They are then fed over a 5-month period and then slaughtered, at which time their weight averages $500 \mathrm{kgs}(1100 \mathrm{lbs})$.

A mass balance diagram for beef production is presented in Figure 3 . The internal flow lines describe the redistribution of certain input elements. The input data used are listed in Table A3, and output data used are presented in Table A4.

PORK PRODUCTION

A considerable diversity exists between values reported for specific inputs and outputs involved in pork production. This is partially due to the wide variety of diets suitable to swine. The diagram for mass balances as presented in Figure 4 represents an average of (or perhaps compromise between) these reports. Input data used in arriving at the balances are listed in Table A5 and output data in Table A6.

\section{FISH PRODUCTION}

Aquaculture in the form of $f$ ish production is an old practice in the Orient and is receiving increasing attention in this sountry. While carp constitute the favorite subjects for fish farming in the Orient, in the U.S., the two types of fish most widely grown are the catfish and trout. Catfish is a favorite because it is a "warm water" fish and is fairly tolerant of adverse conditions, and yet its meat is considered to be quite delectable.

Trout are more fastidious in their requirements, but. the diffir.ultipas encountered in the ir culture are compensated by the high quality of the fish meat and hence an assured demand for the product. 


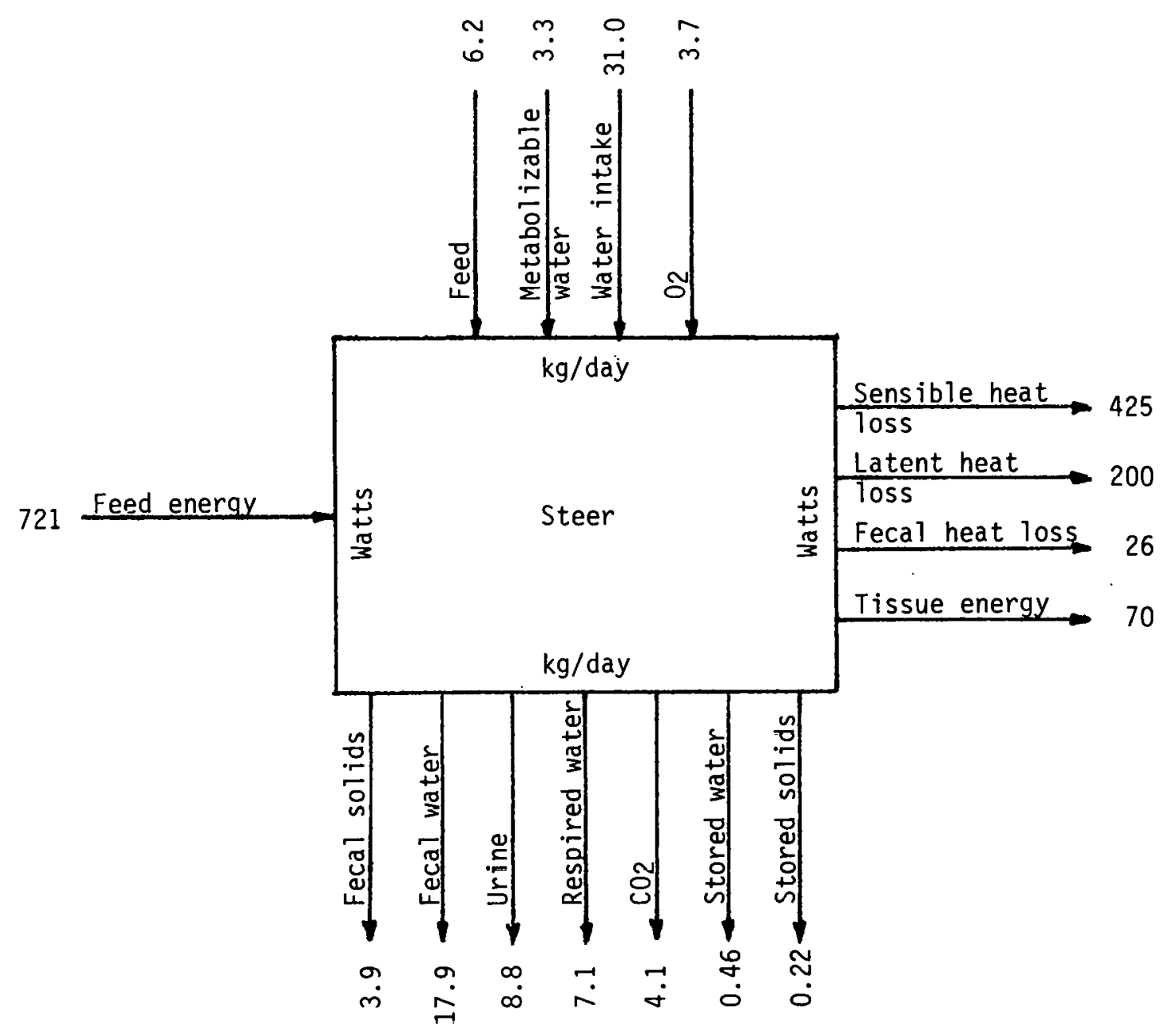

Figure 3. Mass balance diagram for beef production. 


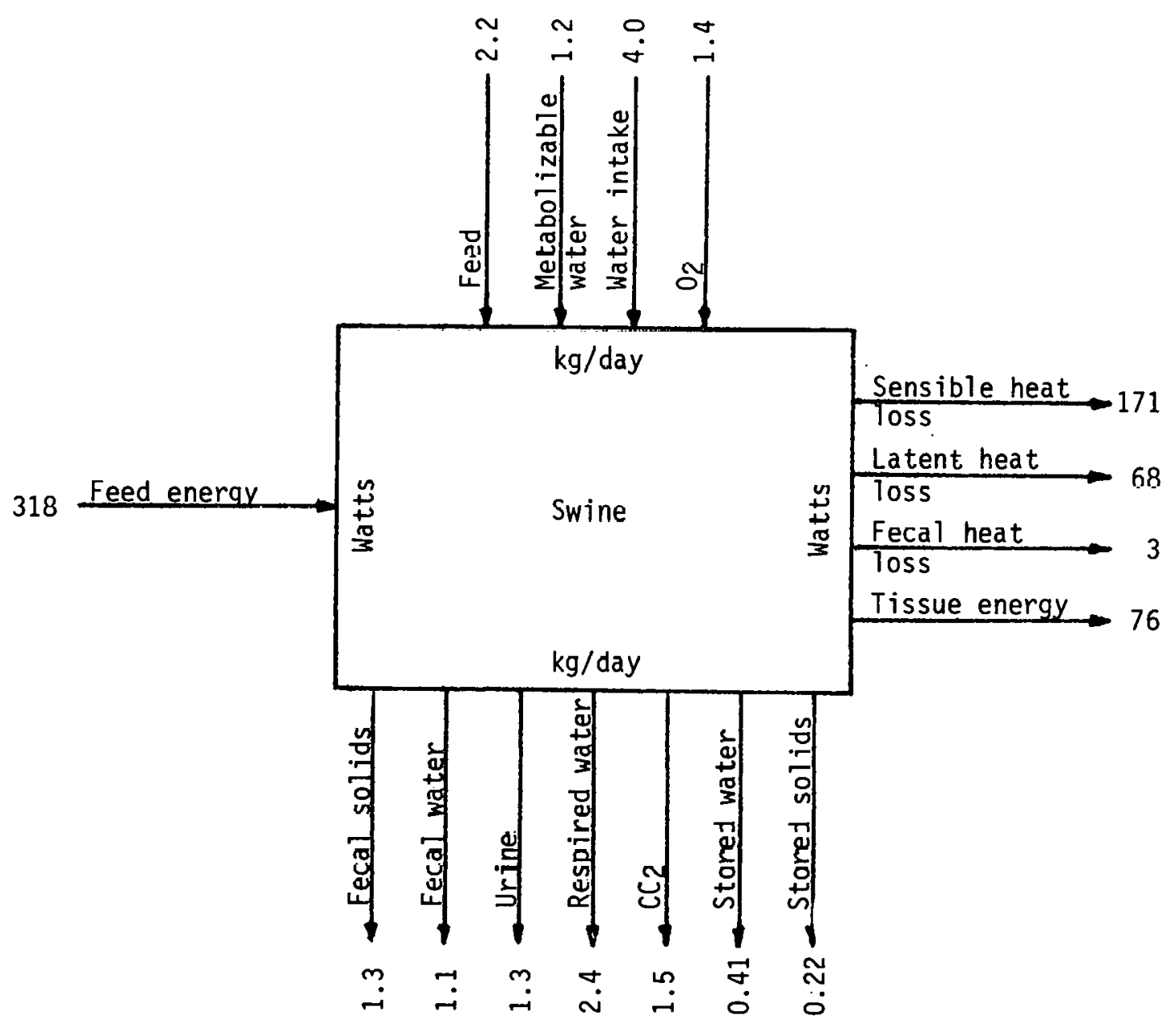

Figure 4. Mass halance diagram for pork production. 
The favorite of designers of "closed" food production complexes, however, is the group of fish known as tilapia. Inasmuch as the favorable aspects of tilapia culture are well-known; there is no need to dwell upon them here. Suffice it to point. out that tilapia have the advantage of being able to use almost any waste as a source of nutrient and are tolerant of adverse conditions. Moreover, the pond water may consist of 60 to 70 percent seawater (20.2-25.0 percent salinity) without adversely affecting production. The maximum salinity at which they can survive is 53.5 percent, and they reproduce only up to a maximum of 30 percent. (1)

Despite being a practice of long standing, precise data founded on scientific observation on fish farming are extremely scarce in the literature. However, sufficient data are on hand to permit the development of plausible systems (especially for catfish, tilapia, and trout). Because of the availability of data on the latter three types, they were selected for attention in the present investigation. Although it was realized at the start the chances of advantageously fitting in trout farming in waste heat utilization schemes are slim, sufficient data were collected to confirm that conviction.

The principal inputs to be considered in tilapia, or for any fish culture, are water, feeds, oxygen, heat, and electric power for the pond operation. The type of food required varies with the fish being raised. For instance, in tilapia culture, the range may be from manures to algae or protein pellets. 0xygen demand ranges from $22-38 \mathrm{mg} / 100 \mathrm{~g}$ body weight tor tilapia (a "warm water" fish) to $49-80 \mathrm{mg} / 100 \mathrm{~g}$ body weight for trout (a "cold water" fish). (2) Heat input, of course, depends upon the temperature requirements of the fish. Trout require relatively low temperatures in that their optimum is from 12 to $16^{\circ} \mathrm{C} .(3,4)$ On the other 
hand, those temperatures are practically lethal for tilapia. (5) Their optimum is with in a range of 22 to $35^{\circ} \mathrm{C} .{ }^{(6)}$ Power requirements will also vary sharply according to the type of fish. Thus, because of the high $\mathrm{O}_{2}$ demand of trout, their culture involves a far higher degree of pond circulation and agitation than does that of warm water fish.

The principal outputs are fish meat, proteinaceous wastes, and body and metabolic wastes (e.g. manure and $\mathrm{CO}_{2}$ ).

\section{Catfish Production}

A mass balance dlagram for catfish farming is presented in Figure 5. This model is basege upon raceway s.ulture. Nn estimated value is given to the NPK output. In this case, the absence is due to the inability to reconcile the small amount of available data. The input data used in making the balances are listed in Table A7, and output data in Table. AR.

\section{Tilapia Production}

In the tropics, tilapia culture often is carried out with the use of cages. Several advantages accrue from this practice. The fish remain quiescent instead of being engaged in territorial competition, as occurs When they are crowded in extreme confinement. Moreover the practice simplifies harvesting, since the fish alreadv are segregated according to age. In those cases in which a hign mortality rate occurs, the cages must be serviced frequently to protect the surviving fish.

The lower production rates in tilapia culture in the U.S. indicate that this country lags behind other countries, especially the tropics. However, if $1, S$. researchers were to adopt a more systematic and quanti tative approach, the lag would soon disappear. Unfortunately, some of the work being done on tilapia culture seems to be guided by the practices followed in intensive catfish and trout culture. Intensive methods 
Notes:

Calculations based on 1 Raceway $1.2 \mathrm{~m} \times 1.2 \mathrm{~m} \times 15 \mathrm{~m}$, $7000 \mathrm{fish}$ at $0.25 \mathrm{~kg} / \mathrm{fish}$

$\mathrm{T}_{\mathrm{H}_{2} \mathrm{O}}=30^{\circ} \mathrm{C}, \mathrm{T}_{\text {air }}=20^{\circ} \mathrm{C}$

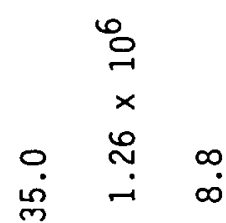

* Biological oxygen Demand

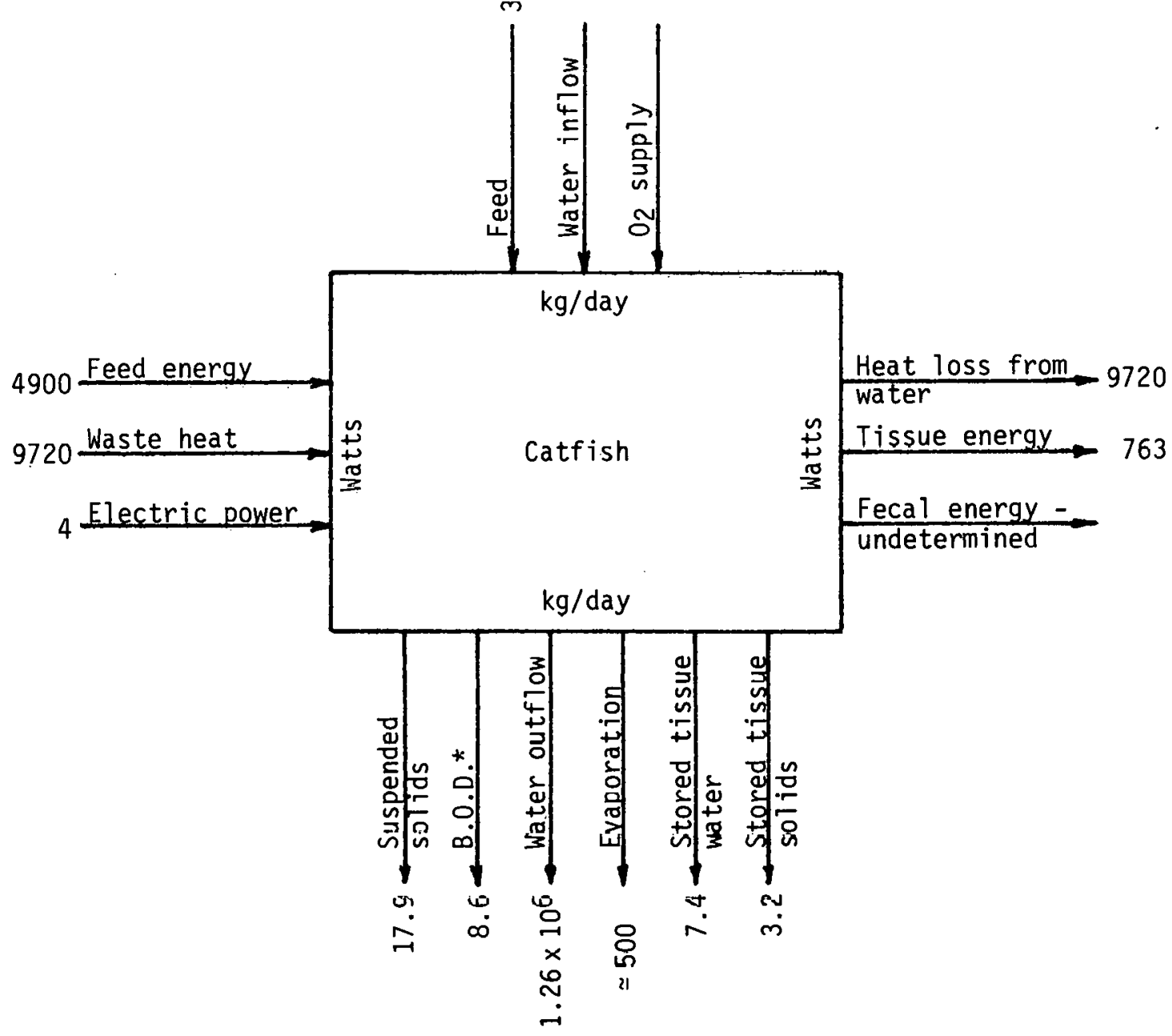

Figure 5. Mass balance diagram for catfish production. 
are more dependent upon energy than is the case with commercial fishing, despite the higher concentrations of fish characteristic of intensive culture.

A block diagram of a tilapia-algae production pond showing relations of inputs and outputs based on a report by 01szewsk $i^{(7)}$ is shown in Figures 6 and 7; a mass balance for tilapia culture is presented in Figure 7. The balances in the figure are based on reasonab le assumptions which could be made from information reported in the literature. No numbers are given for water throughput, because they vary with the conditions under which the pond is operated. A 2:1 food to meat conversion was assumed; such a ratio should be easily attained under optimum conditions. The feed is assumed to be of algae and to have a prote in content of 50 percent with an energy value of $18.0 \mathrm{MJ} / \mathrm{kg}$ protein, plus a limited amount of complex carbohydrate and lipids. The meat analys is is taken from the generalized analysis given by Spector ${ }^{(8)}$ for fish. Fecal solids were determined by subtracting meat solids plus oxidized solids frnm input. solids.

Various input and output data related to tilapia culture are listed in Tables $A 9$ and $A 10$ respectively. The wide range of yields listed under that heading in Table AlO is an excellent illustration of the importance of environmental conditions in tilapia production as well as of the intensiveness of the culture techniques used.

\section{Trout Production}

Although for reasons stated earlier no mass balances were made with respect to trout production, a moderate amount of data were collected on the subject. The information is recorded in Tables All and A12. A perusal of Table All furnished evidence for the unsuitability of trout 


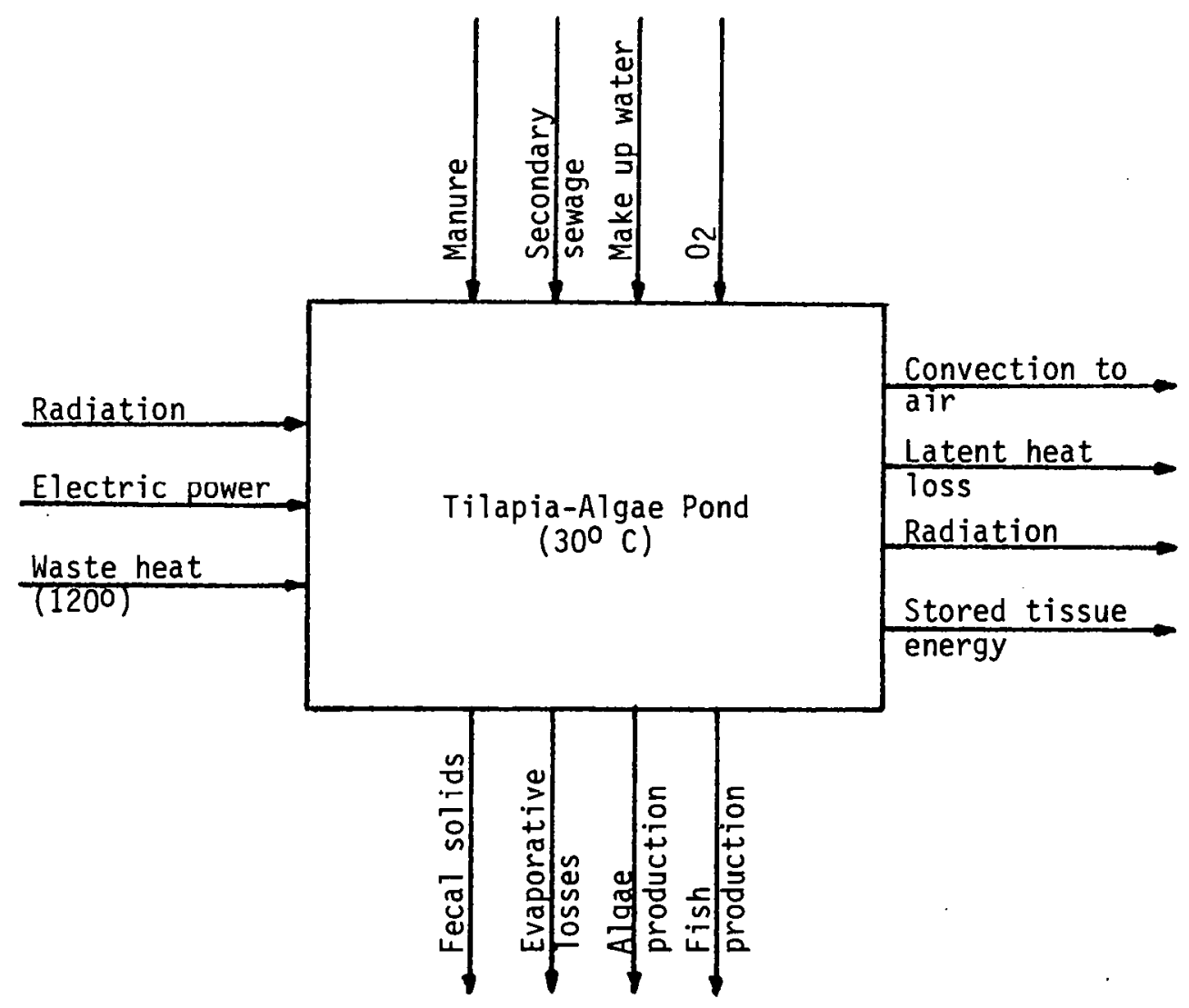

Figure 6. Diagram of inputs and outputs for a tilapia-algae pond. 
Note:

Calculations based on

0.05 ha pond culture $1000 \mathrm{fish}$ at $0.1 \mathrm{~kg} / \mathrm{fish}$

$\mathrm{T}_{\mathrm{H}_{2} \mathrm{O}}=30^{\circ} \mathrm{C}, \mathrm{T}_{\mathrm{air}}=20^{\circ} \mathrm{C}$

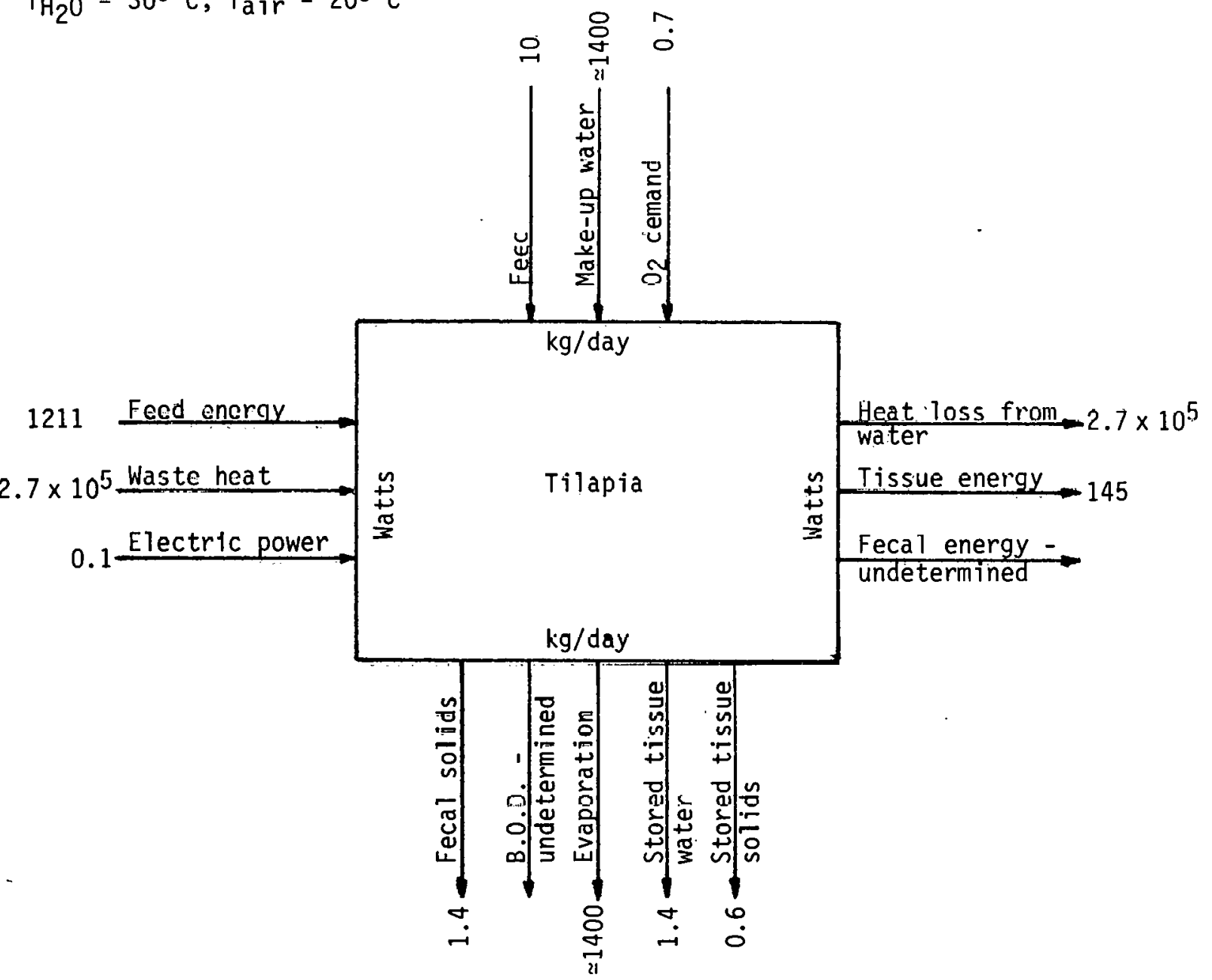

Figure 7. Mass balance diagram for tilapia production. 
farming in an energy-agro-waste complex. The requisite low water temperature, the high oxygen demand, and the inability to use common wastes as a nutrient source are not reconcilable with the conditions of such a complex. The highest value $(2.8 \mathrm{~kg} / \mathrm{l} / \mathrm{min})$ listed for yield in Table Al2 is taken from Bardach. (9) The estimate is based on reported yields obtained in a trout farmina district in the Idaho-Snake River valley. According to Bardach, a more accurate description of high yields is to report them in terms of flow rate rather than of area of volume because they are functions of effective flushing of growth inhibiting wastes from the trout raceways. However, since fish farming involves a given area or volume devoted to that purpose, reporting in yield per volume or area is equally usefur.

\section{Unit Processes for Plant Production}

Both open field and greenhouse growing play valuable roles in agriculture around the world. Similarly, both of these agricultural techniques can serve in valuable and different roles in an energy-agro-waste complex. Several unit process models were consequently developed for different methods of plant production as we 11 as different crops.

\section{GREENHOUSE PLANT PRODUCTION}

The primary advantages of greenhouse growing lie in the ability to control the plant environment and in efficient land utilization. These features also make greenhouses well-suited to utilization in an energyagro-waste complex. Waste heat from the power plant can be used to heat the greenhouse providing the required a ir temperature for the plants. Heating is currently the major expense for greenhouse growers. Efficient land utilization is achieved both through high crop yields and use of 
land unsuited to open field growth. Consequently, greenhouses can be more conveniently sited in a complex than an open field process.

A generalized diagram showing major inputs and outputs of a greenhouse unit process is presented in Figure 8.

Tomato production is an excellent example of the use of the greenhouse in crop production, because tomatoes are the most widely grown greenhouse crop in the world. There are two good reasons for the latter, namely, the existence of a steady high consumer demand for tomato fruit and the high yielding capability of the tomato plant.

A mass balance diagram of a tomato greenhouse is presented in Figure 9, and the data used in arriving at the mass balances are listed in lable B1. A collection of yields reported in the literature is given in Table B2. Another vegetable commonly grown in greenhouses is the cucumber. Reported yields of cucumbers range from 325 tonnes fruit/ha/yr to 739 tonnes fruit/ha/yr, $(10,11)$ and average at 525 tonnes fruit/ha/ $\mathrm{yr}$. In terms of biomass production, the yield in vines is about 13.5 percent that of the fruit. The average of fruit and vine would then be 596 tonnes/ha/yr.

Roses and carnations are two flower crops most commonly grown in greenhouses. Yields reported for roses range from $1.73 \times 10^{6}$ stems $/$ ha /yr to $1.67 \times 10^{\overline{6}}$ blooms $/ \mathrm{ha} / \mathrm{yr}$.

Reported temperature requirements for tomatoes range from $14^{\circ} \mathrm{C}$ to $20^{\circ} \mathrm{C}$ for the night time, and from $21^{\circ} \mathrm{C}$ to $24^{\circ} \mathrm{C}$ for the daytime. Cucumbers prefer somewhat higher temperatures. Thus, the reported night time temperatures range from 18 to $27^{\circ} \mathrm{C}$. Estimates of the heating requirements to maintain the vines at the appropriate levels under various conditions are listed in Table B3. (12) 


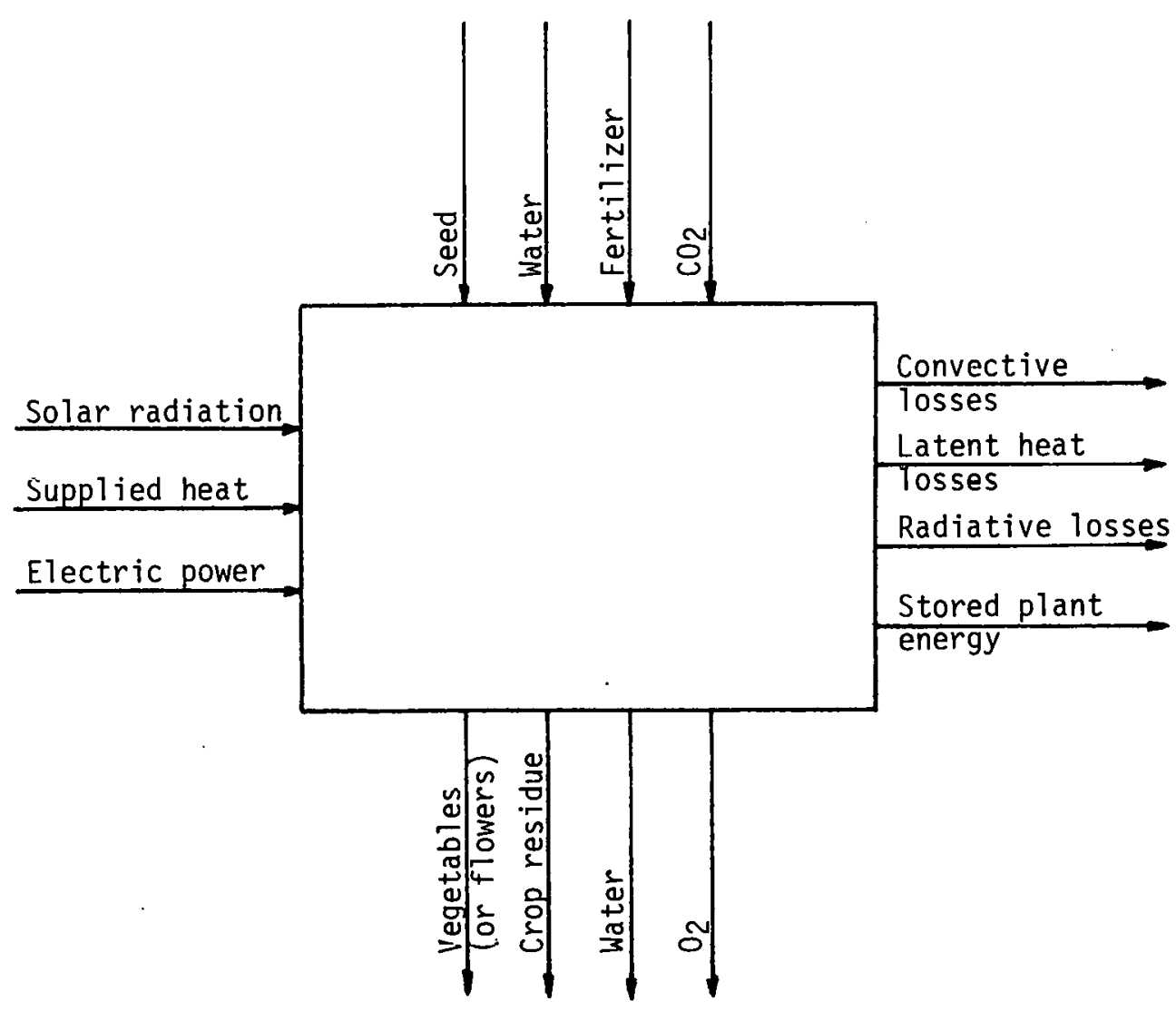

Figure 8. Generalized diagram of a greenhouse unit process. 


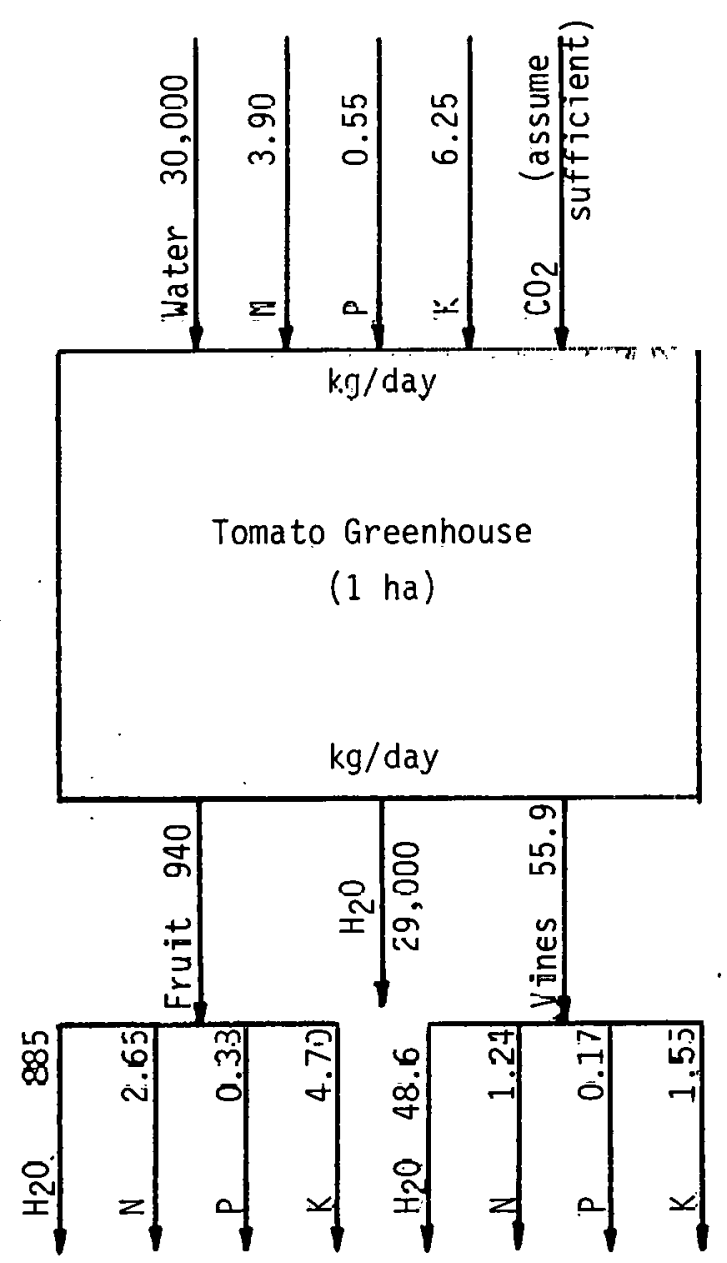

Figure 9. Mass balance diagram of a tomato greenhouse unit process. 
Data on electrical requirements as collected from a variety of

reports indicate an electrical requirement of 75 to $100 \mathrm{~kW} / \mathrm{ha} .(13-15)$

OPEN FIELD PLANT PRODUCTION

Open field growing can serve in several compatible functions for an energy-agro-waste complex. It can utilize various nutrients in wastestreams for fertilizer. Grain can be grown to feed livestock in the complex. Crop productivity can be enhanced by undersoil heating and hence serve as a cooling source for recirculating condensor cooling water. Or condensor cooling water can be used for spray irrigation of fields for once-through systems, also serving to reduce warm water discharge into natural bodies of water. A complex within an urban area would probably be restricted in its available land area, and thus open field growing would correspondingly be restricted. However, in complexes located outside urban areas open field growing offers unique potential.

The nitrogen, phosphorous and potassium (NPK) requirements of several grain crops are depicted in Figures 10 through 14 . The numbers in the balances are based on annual inputs and outputs per hectare. In making the balances for corn and sorghum, it was assumed that field residues would be equal to 0.85 of that of the grain, both on a dry weight basis. This number is rather conservative in view of the fact that the reported values range from 0.85 to 1.35 . The latter value is that reported for corn residue in California. (16) A reason for using the conservative estimate is that it allows for some residue to remain in the field and there serve to promote soil conditioning. Additional data pertinent to forage crops are given in Table B4 along with total NPK percentages of various grains. A further discussion of nutrient uptake is contained in Append ix B. 


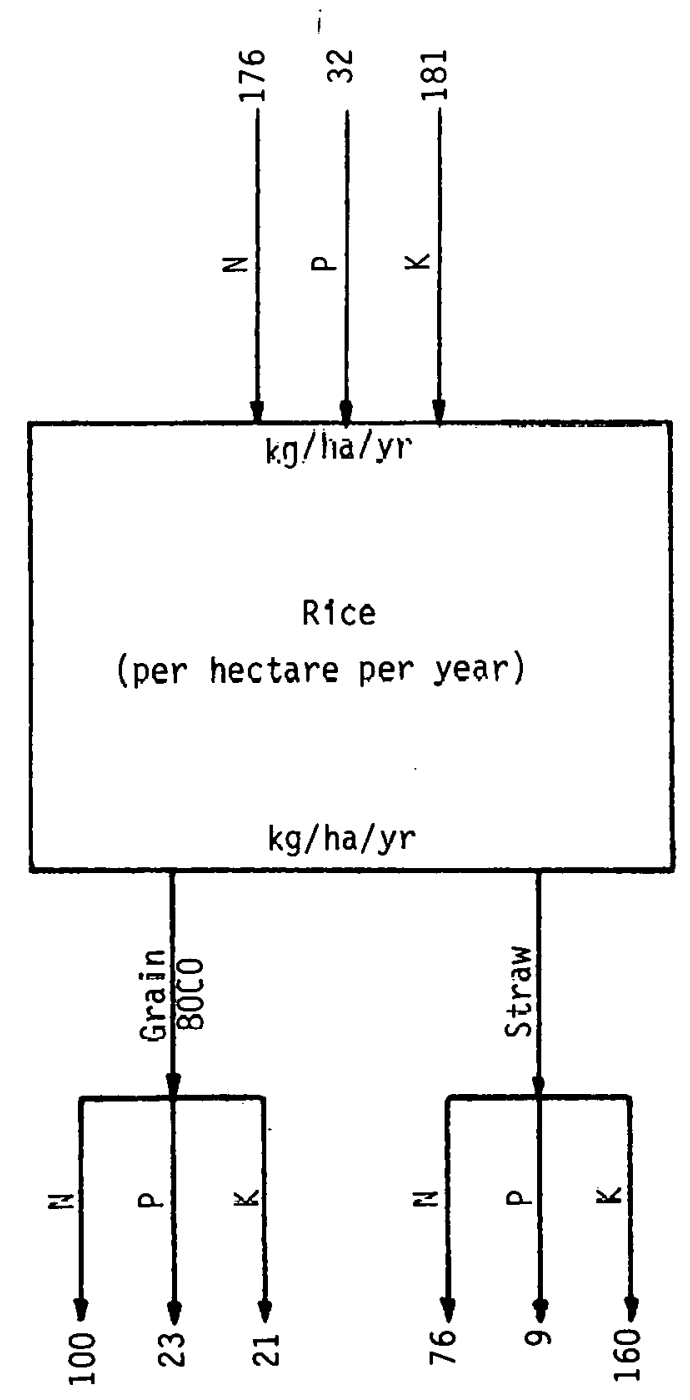

Figure 10. NPK mass balance diagram for rice production. 


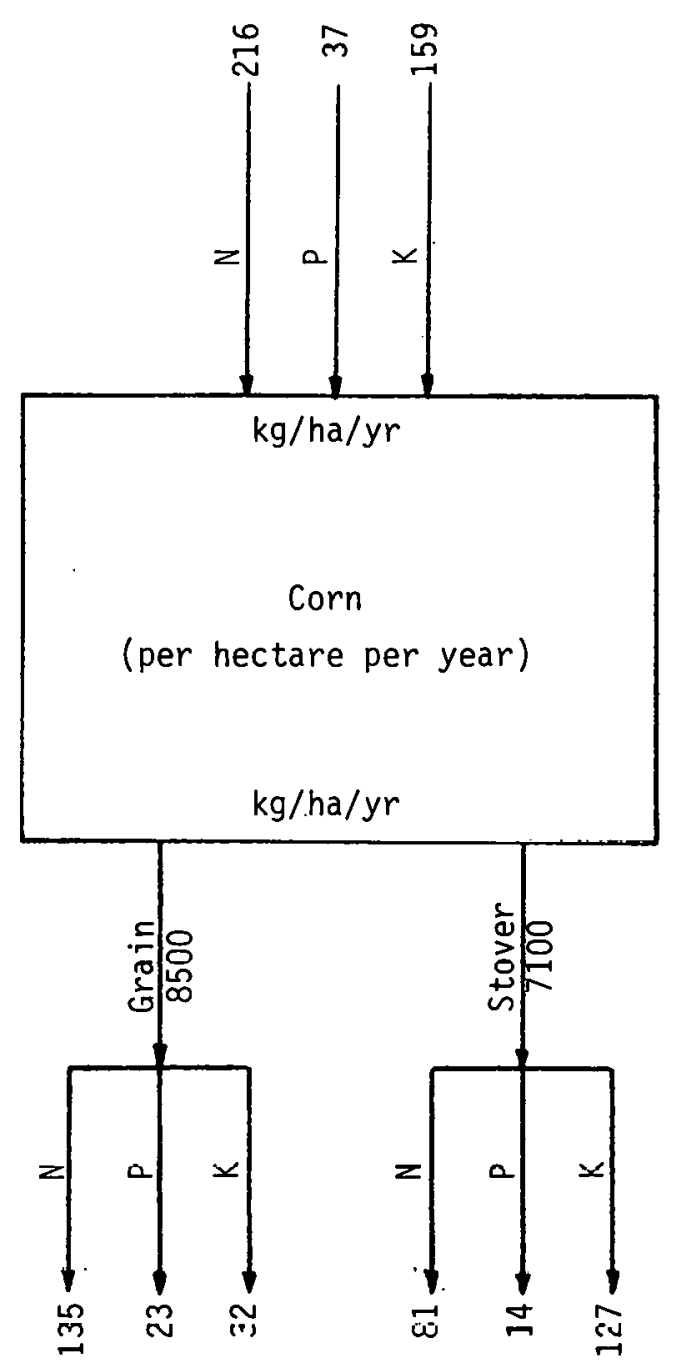

Figure 11. NPK mass balance diagram for corn production. 


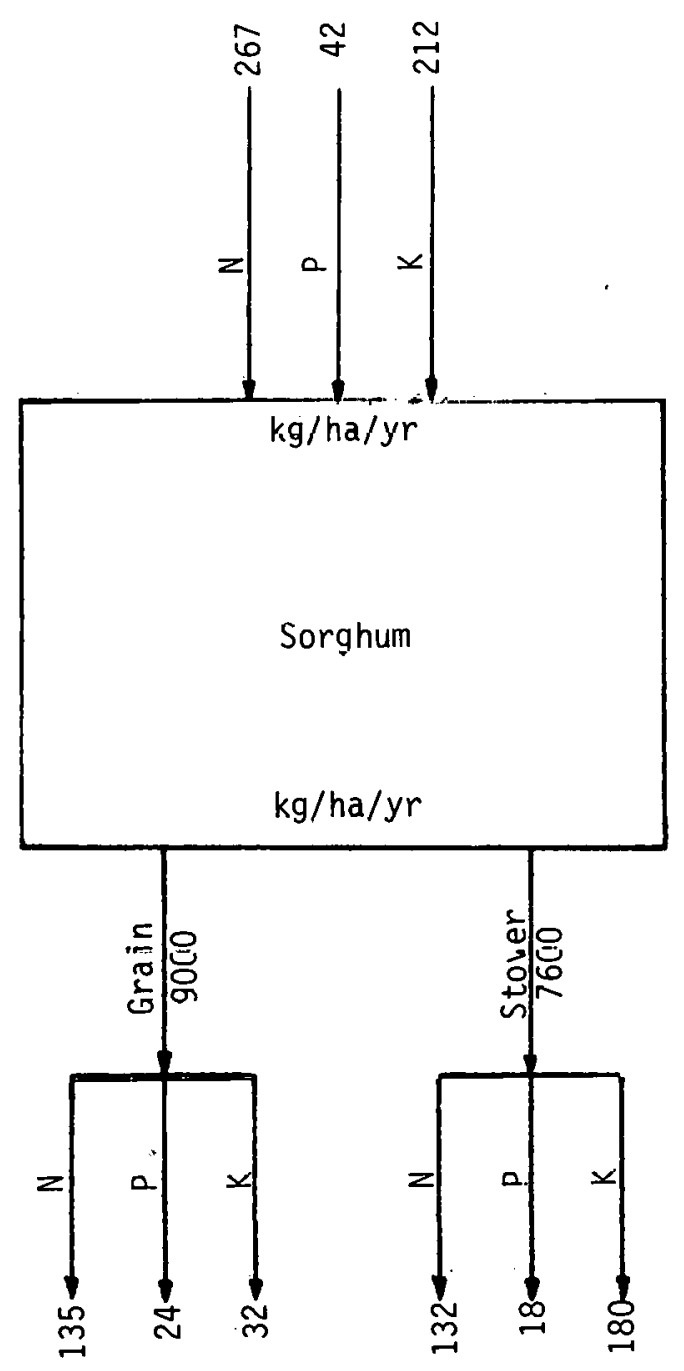

Figure 12. NPK mass balance diagram for sorghum production. 


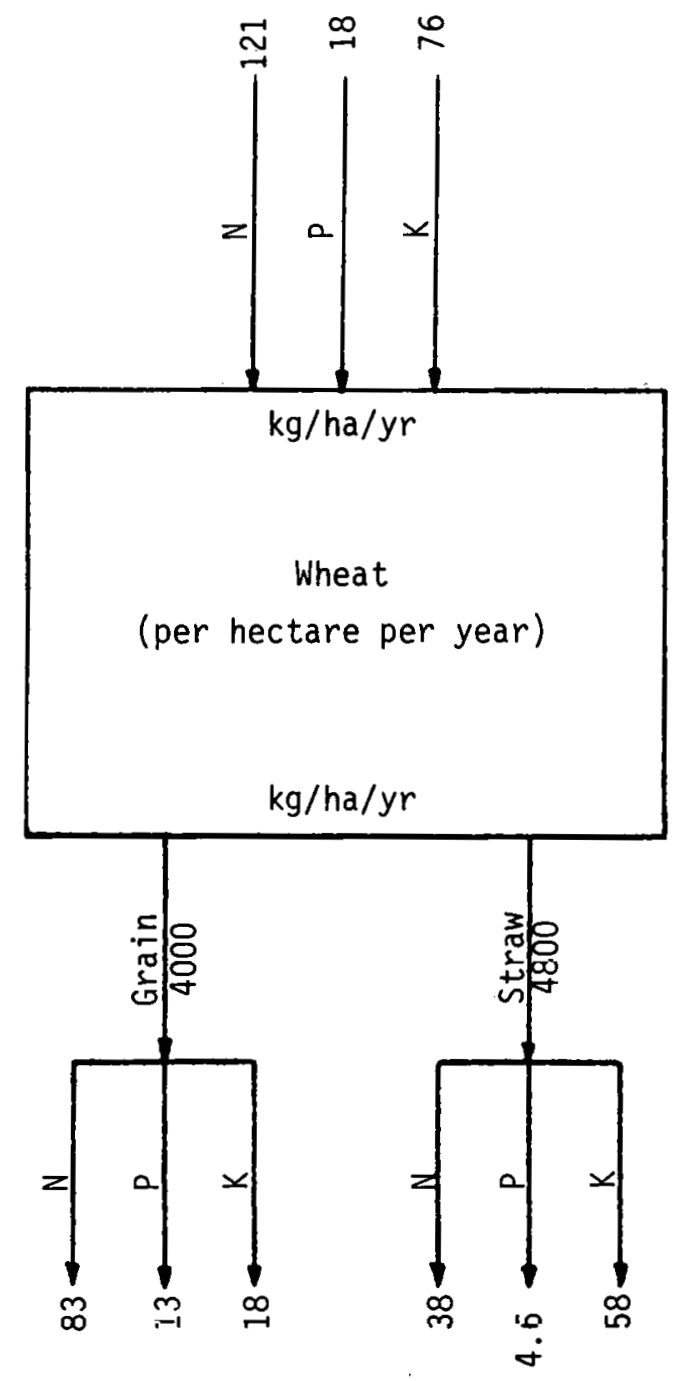

Figure 13. NPK mass balance diagram for wheat production. 


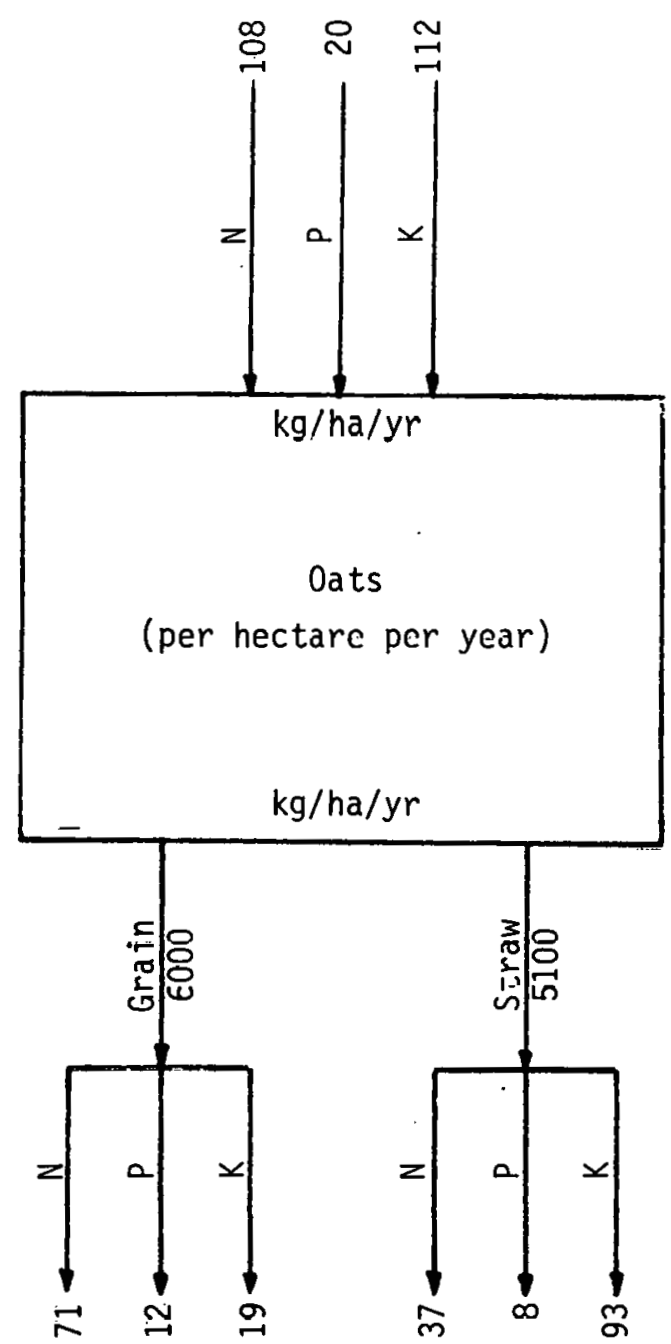

Figure 14. NPK mass balance diagram for oat production. 
WATER HYACINTH PRODUCTION

With in the past few years, and especially as spurred on by reports from the NASA group, the water hyacinth again has begun to attract attention as a means of wastewater treatment. Reported results indicate that the plant is effective in cleaning up waters contalning organic wastes, and to some extent in the removal of heavy metals. The role of the plant in upgrading wastewaters is twofold, namely oxygenation and assimilation of bacterial breakdown products in the wastewaters. The oxygen is released into the water medium from the submerged green portion of the plant. Inasmuch as a substantial part of the plant is emergent and the submerged portion is shaded, the extent of oxygenation is much less than that with completely submerged aquatic plants. The removal of heavy metals is primarily a function or assimilation, absorption, and adsorption by the plant; and secondarily of alterations in the suspending medium (water) brought about by the metabolic activities of the plant. While the utilization of water hyacinth culture in wastewater treatment has many advantages, it also is attended by substantial difficulties. Advantages are in the form of the rapid growth of the plant, which in turn ensures a rapid and effective upgrading of the wastewater. Another, but debatable, advantage is the possibility of utilizing the hyarinth r.rnp as a feedstuft for livestonck. It.s characteristics as a feedstuff are indicated by the data in lable B6. Disadvantages are: (1) an essential limitation to frost-free geographical areas; (2) danger of plants escaping into waterways; and (3) difficulty in harvesting. The major problem in terms of utilization as a feedstuff is the magnitude of the water content. The plant typically has a 95 percent. water conntent. 
Untortunately, water expressed from the plant contains a sizeable proportion of the animal nutrient content of the plant.

A mass balance diagram for water hyacinth production is shown in Figure 15. The input nutrient elements may exist in an assimilable form in the sewage at the time of introduction into the system, or after introduction is converted into such forms by bacteria indigenous to the sewage and the pond culture. Potential limiting factors are visible light energy, $\mathrm{CO}_{2}$, nutrient concentration and balance, and temperature.

\section{Alyae froduction}

Research and experimentation on the use of algae culture in wastewater treatment and production ot an animal feedstuff has a long history that extends back to the early 1950's and early 1960's.

The basic principles involved are not unlike those pertinent to water hyacinth culture. The differences are in the nature of the plants involved, the degree and extent of the basic process activities and results, and of course, in the operation of the two systems.

Generally, the planktonic algal genera (e.q. Chlorella, Scenedesmus, Euglena) are used. Reasons are ease of culture, rapidity of growth, and distribution throughout the water being treated. In terms of food production, the light energy fixation efficiency far surpasses that by the macro-forms. A major disadvantage is the monetary and energy expenditure involved in harvesting planktonic algae. However, recent work done at the University of California (Berkeley) indicates that by manipulating natural processes, a drastic reduction of these expenditures becomes possible.

The rapidity of growth and more or less general distribution of the algal celis throughout the pond water ensures an effective oxygenation of 


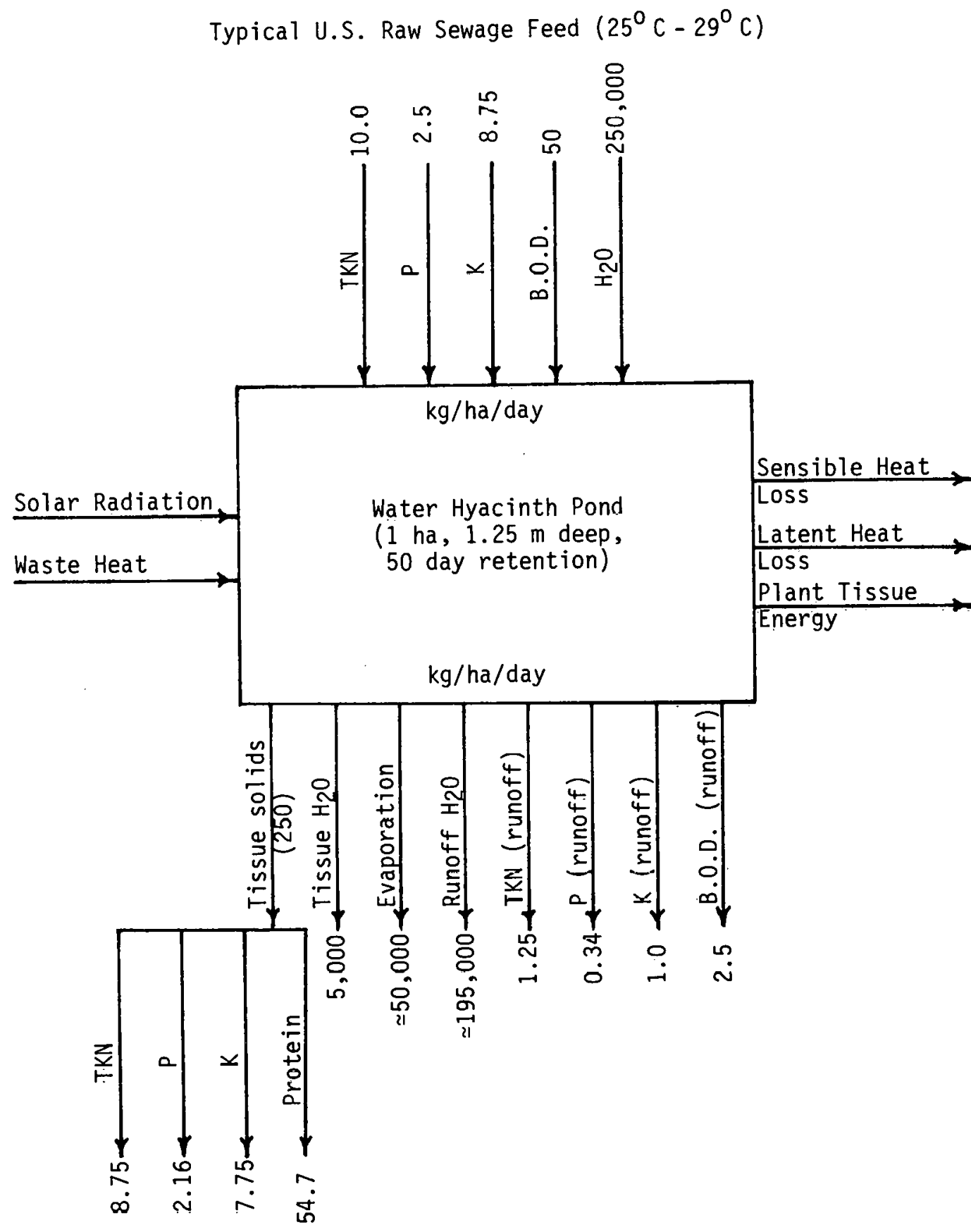

Figure 15. Máss balarice diagram for water hyacinth production. 
the wastewater. As a qeneralization, it may be assumed that for every gram of new cellular material synthesized during photosynthes is, 1-6 grams of $\mathrm{O}_{2}$ are released into the aqueous medium.

The algal product has been demonstrated through animal (chickens, swine, sheep) feeding experiments conducted at the University of California (Davis) to have a nutrient quality comparable to soybean oilmeal. In especially designed ponds, production can range from 44 tonnes (dry wt.) to 110 tonnes/hertare/yr.

The principal types of ponds involving the use of algae may be either tacultative or high-rate. While anaerobic ponds are used for treating heavily concentrated wastes (e.g. rendering plant effluent), algae play a very minor role in their functions. Facultative ponds are so named because they involve both aerobic and anaerobic breakdown, i.e. aerobic in the upper strata, and anaerobic in the lower strata. They normally are (i.e. they should be) at least $1.5 \mathrm{~m}$ deep, and preferably $2.5 \mathrm{~m}$ or more. High-rate ponds may be one of two types, namely, high-rate treatment or alqae production. The high-rate treatment pond is on the order of $1.2 \mathrm{~m}$ deep and is mixed periodically throughout the day. The algae production pond is from 12 to $35 \mathrm{~cm}$ deep and is mixed once or twice a day in the non-raylight hours.

A typical mass balance diagram for an algae production pond is presented in Figure 16. Ns with water hyacinth culture; the input nutrients come from the bacterial decomposition of the organic wastes in the water. Ammonium-nitrogen is the principal nitrogen source for algae, although most forms can utilize certain of the amino acids as nitrogen sources and a few can assimilate urea-nitrogen. Excepting for tolerance of much lower temperatures, the limiting environmental factors are much 


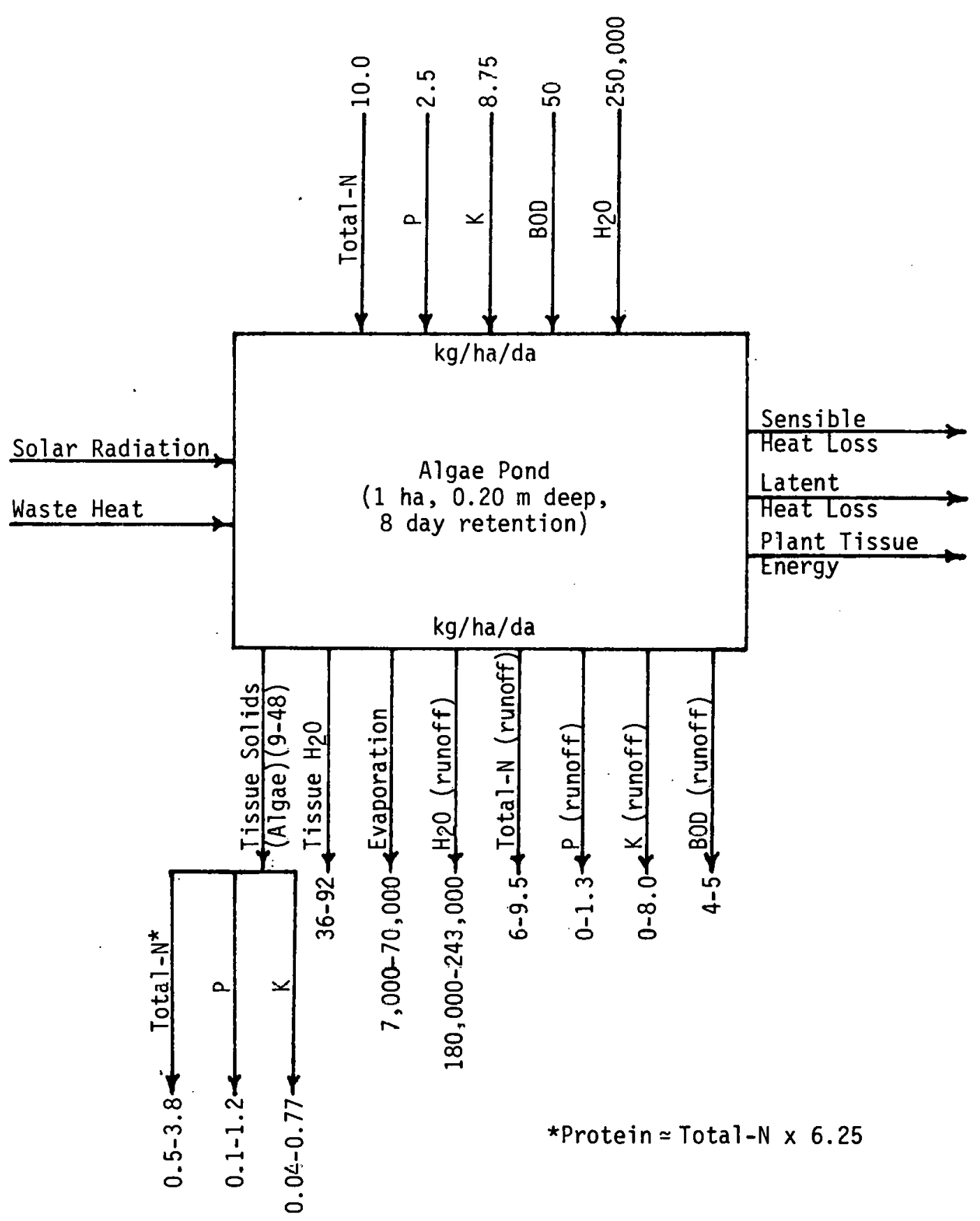

Figure 16. Mass balance diagram for algae production. 
like those for water hyacinth culture. Pertinent data for an algal culture system are presented in Table C. It should be noted that the data are mainly indicative.

\section{Anaerobic Digestion}

An important unit process considered in this section is anaerobic digestion, or as it has come to be popularly known, "biogas production." The reasons for the great surge of interest in biogas production are we 11 documented in the scientific and the popular literatures and need not. receive detailed attention in this report. Suffice it to state here that the anerobic digestion process can be made to serve in an agro-waste complex as a means of converting residues in part to energy and in part to sources of fertilizer elements and soil amendments. Moreover, since the process is well described in the literature, a discussion of the various operational and design parameters is not given. To do justice to either of the two subjects would entail an undue expenditure as far as the present report is concerned.

A mass diagram of pertinent. inputs and outputs of the anacrobic digestion process that are of significance to the present study is given in Figure 17. The balances are based on values reported by Boersma for the anaerobic digestion of swine wastes. (17)

\section{Sewage Treatment Procesees}

The development of a primary-secondary treatment model wạs made a part of the sertinn on unit processes because sewage, whether raw or treated, can serve as an important input in an energy-agro-waste complex. Sewage can serve as a liquid medium in aquaculture both as a suspending medium and as a source of fertilizer elements to plants in 


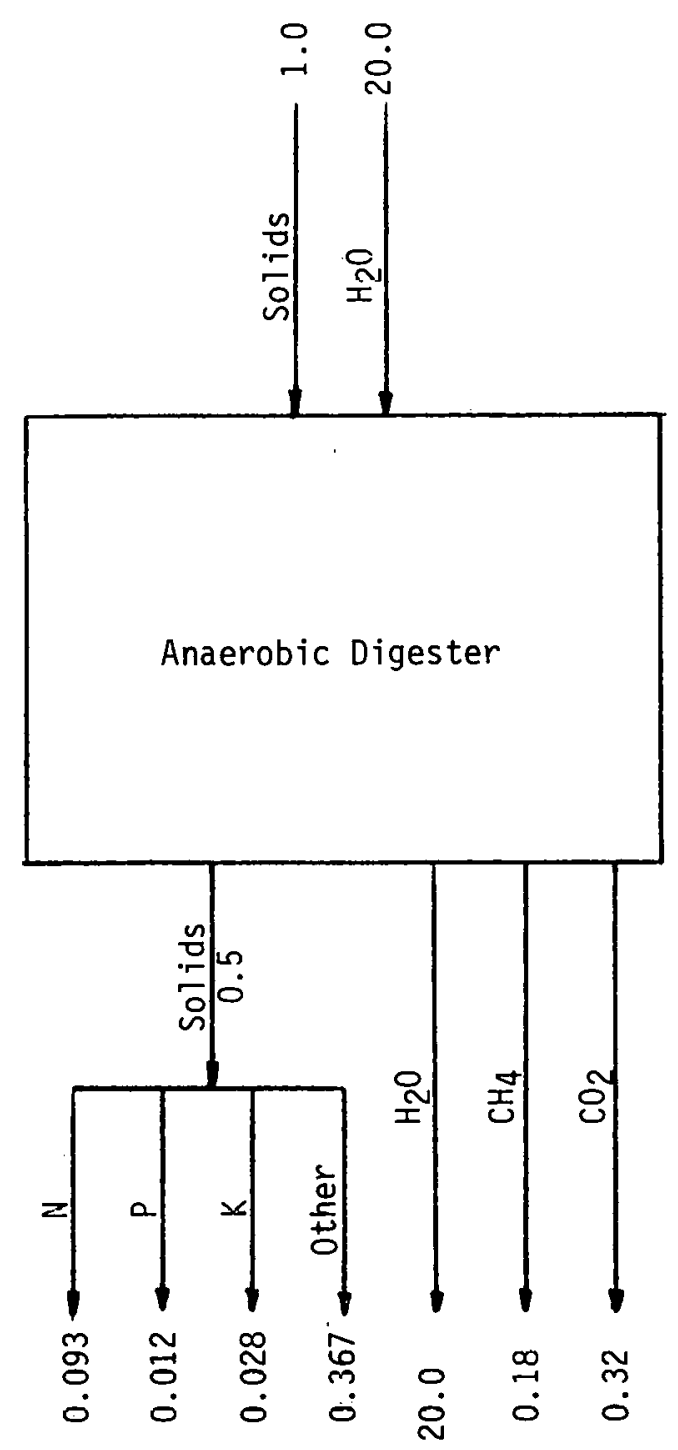

Figure 17. Mass balance diagram for anaerobic digestion process. 
systems involving the production of aquatic plants or as source of nutrients to micro and macrofauna in the systems. With respect to 1 and crops, it again is a source of plant nutrients and of water for irrigation. It can serve as a source of heat in both land and aquaculture.

An idea of the fertilizer value of raw and treated (secondary) sewage may be gained from the data listed in Table $\mathrm{Cl}$. The compositions of raw activated and digested sludges as based on a sampling of reported data are given in Table $\mathrm{C2}$. The data in Table C3 collectively are indicative of the efficiencies of primary and sernndary sewage treatments. Balances in terms of composition and of mass showing the combined effects of primary and secondary treatment are diagramed in Figures 18 and 19 . In the compositional diagram (Figure 18 ), total solids are given the value 1.0. The values in Figure 19 are based on $10^{6}$ liters of raw sewage. It goes without saying that the numerical values in both figures would vary according to the nature of the influent raw sewage and the efficiency of the primary and secondary settling chambers. The solids content of the sludges would increase with an increase in efficiency of the settling chambers; and, converseiy, that of the effluents would decrease. All in a11, however, the numerical values as given in the two figures are fairly typical. A typical flow pattern of incoming solids in a representative sewage treatment plant (Hyperion, Cal.) is indicated by the diagram in Figure 20. As the figure indicates, the plant provides for primary and secondary treatment of the sewage and for the anaerobic digestion of the settleable primary solids and wasted activated sludge. 


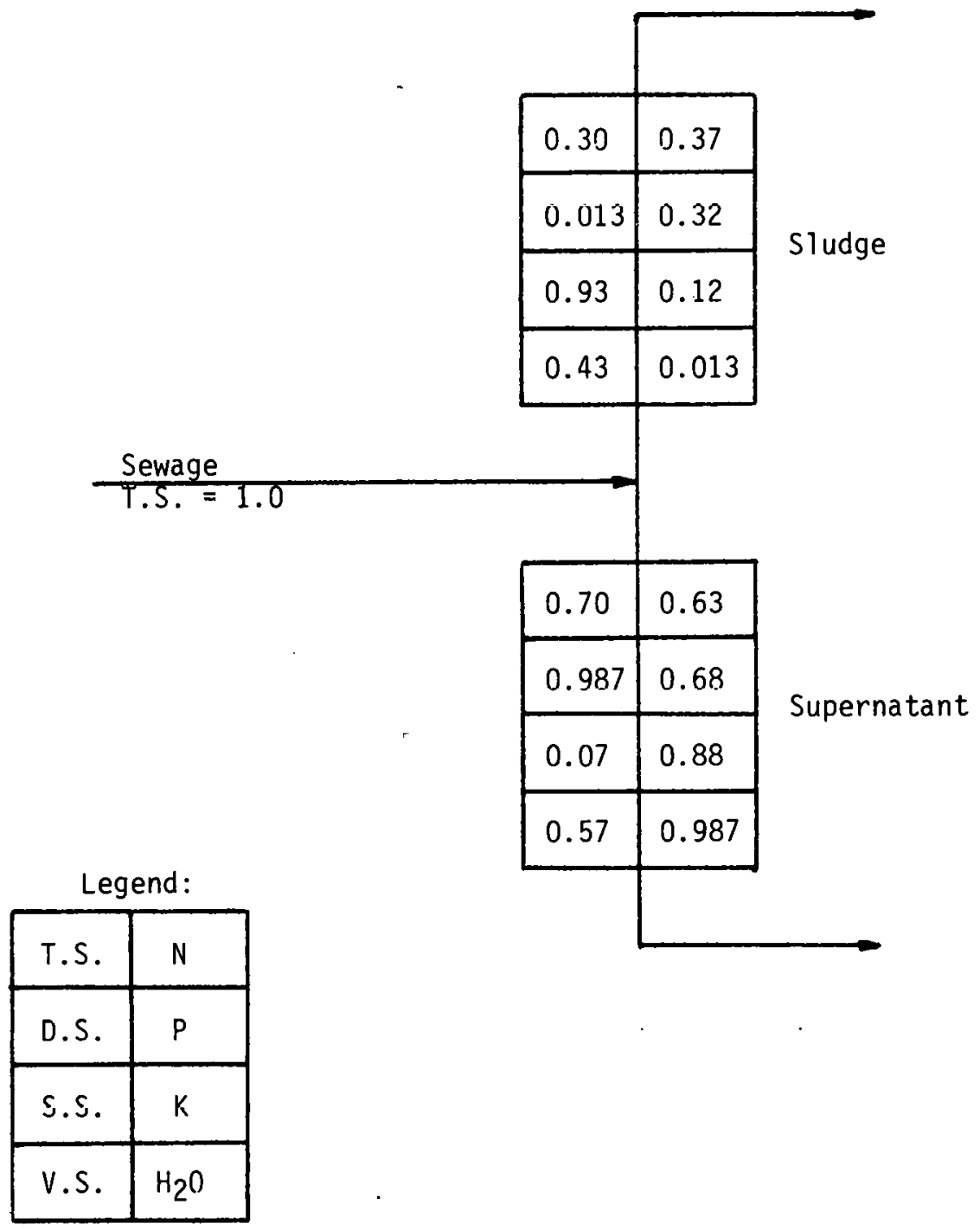

Figure 18. Compositional balance diagram of the combined effects of primary and secondary sewage treatment. 


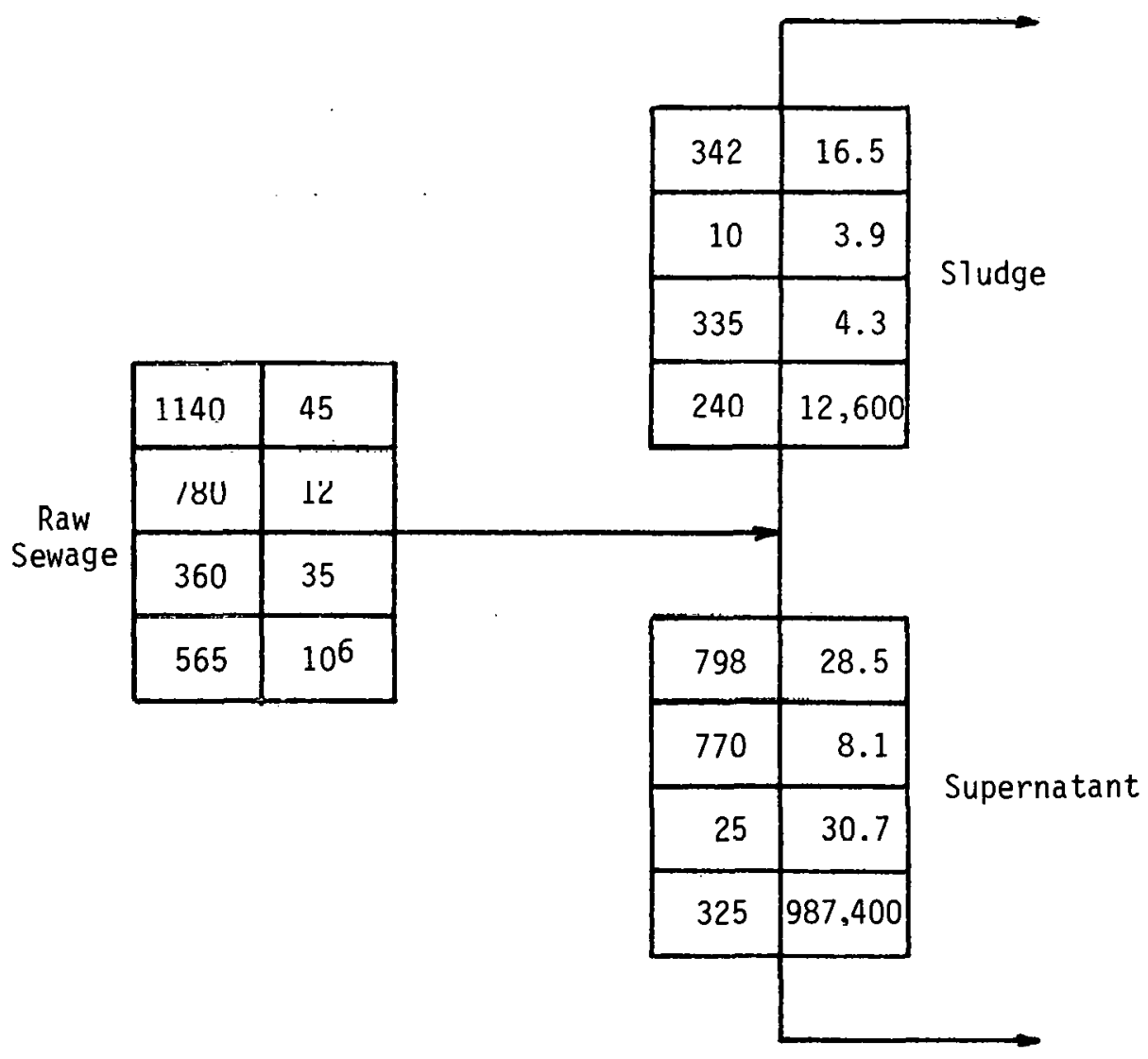

Legend:

\begin{tabular}{|c|c|}
\hline T.S. & $N$ \\
\hline U.S. & $P$ \\
\hline S.S. & $K$ \\
\hline V.S. & $\mathrm{H}_{2} \mathrm{O}$ \\
\hline
\end{tabular}

Note:

1. Based on $10^{6}$ liters of sewage.

2. Values given in kilograms dry weight (except $\mathrm{H}_{2} \mathrm{O}$ ).

Figure 19. Mass balance diagram of the combined effects of primary and secondary sewage treatment. 


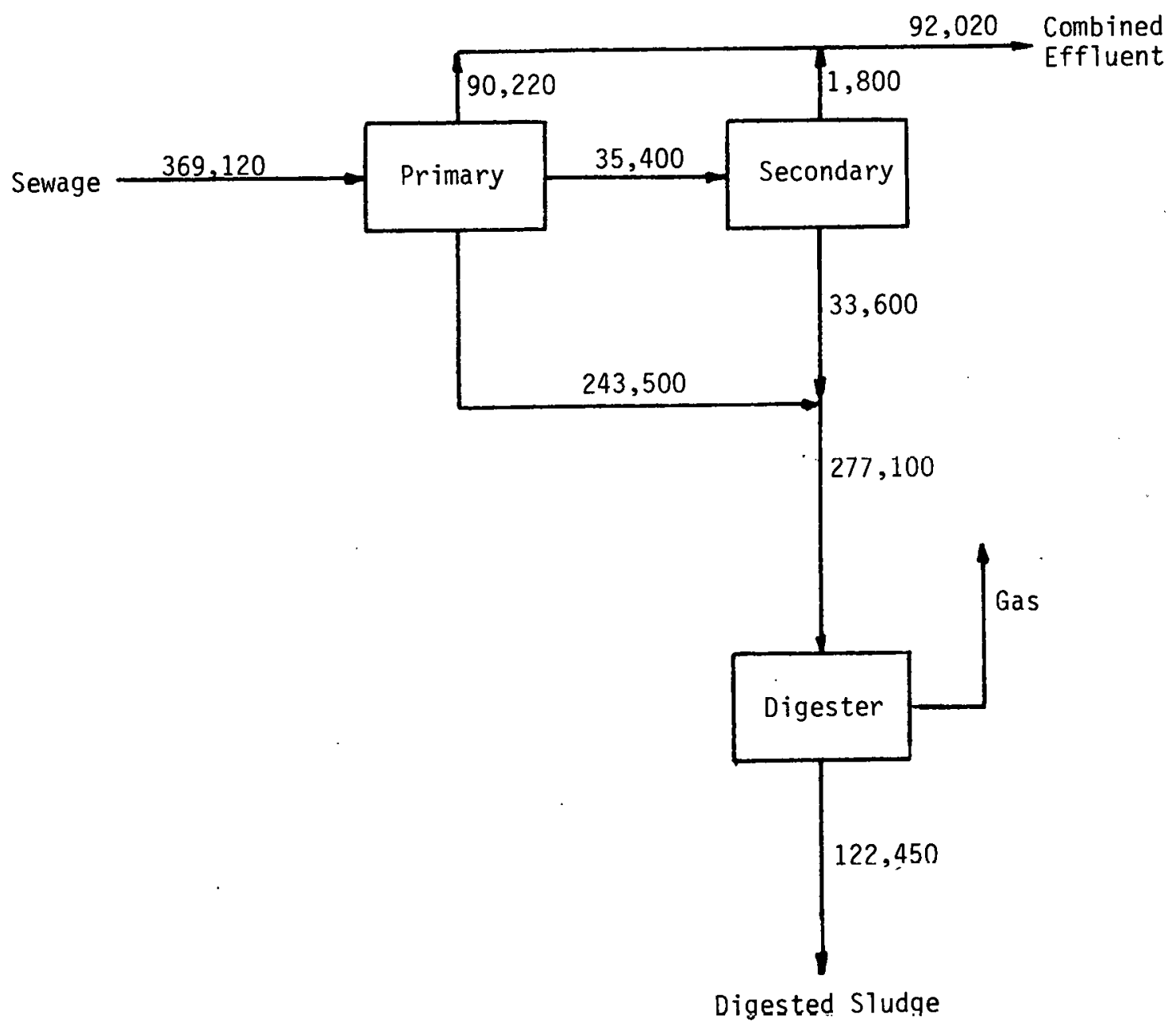

Figure 20. Flow pattern of suspended solids in a sewage treatment plant $(\mathrm{kg} /$ day $)$. 
POTENTIAL INTEGRATED SYSTEMS

Having completed mass and, to some extent, energy balances for a number of likely candidate unit processes, the next logical step in the overall investigation was to integrate selected processes into what were deemed potentially useful and feasible systems or complexes. Table 2 demonstrates the potential roles of various unit processes in the integrated complexes. In the conduct of this phase of the work, the mass balances provided the information as to the nature and amounts of inputs and outputs of individual processes needed in selecting and positioning those deemed suitable to a given system. Ten potential systems were deve loped.

While the diagrams of the systems as presented in this section of the report are qualitative in nature, they do show interrelationships and provide sufficient information for sound assumptions regarding their practicaltty. The order in which they are discussed has no bearing on their comparative feasibilities.

\section{Refeeding of Wastes}

Although refeeding of animal wastes to livestock is still unconventional, a considerable amount of work has demonstrated the feasibility of a variety of refeeding schemes. (18) Animal waste contains protein and other required nutrients which can be reclaimed to supplement livestock feed. It is essential, however, to control the passage of contaminants contained in wastes such as disease-producing organisms, parasites, 
Table 2

Potential Roles of Unit Processes in Integrated Complexes

\begin{tabular}{|c|c|c|c|c|}
\hline Unit Process & $\begin{array}{c}\text { Primary } \\
\text { Role in System }\end{array}$ & $\begin{array}{l}\text { Use of } \\
\text { Waste Heat }\end{array}$ & $\begin{array}{c}\text { Possible } \\
\text { Recycled Inputs }\end{array}$ & $\begin{array}{c}\text { Possible } \\
\text { Recycled Outputs }\end{array}$ \\
\hline Chicken & Meat Production & Housing & $\begin{array}{l}\text { Cattle Manure, } \mathrm{CH}_{4} \text { for } \\
\text { Heating, Slaughter Wastes } \\
\text { Crop Residues, Algae }\end{array}$ & $\begin{array}{l}\text { Manure, Slaughter } \\
\text { Wastes, Litter }\end{array}$ \\
\hline Cattle & Meat Production & Housing & $\begin{array}{l}\text { Chicken Manure and Bedding, } \\
\text { Water Hyacinths, Crop } \\
\text { Residues, Algae }\end{array}$ & $\begin{array}{l}\text { Manure, Slaughter } \\
\text { Wastes }\end{array}$ \\
\hline Swine & Meat Production & Housing & $\begin{array}{l}\text { Cattle Manure, Water } \\
\text { Hyacinths, Crop Residues, } \\
\text { Algae }\end{array}$ & $\begin{array}{l}\text { Manure, Slaughter } \\
\text { Wastes }\end{array}$ \\
\hline Catfish & Fish Production & Water Warming & Feedlot Manure, Algae & $\begin{array}{l}\text { Slaughter Wastes, } \\
\text { Fish Wastes }\end{array}$ \\
\hline Tilapia & Fish Production & Water Warming & Algae, Slaughter Wastes & $\begin{array}{l}\text { Slaughter Wastes } \\
\text { Fish Wastes }\end{array}$ \\
\hline Greenhouses & $\begin{array}{l}\text { Plant Production } \\
\text { (Vege., Flowers) }\end{array}$ & $\begin{array}{l}\text { Maintenance of } \\
\text { Opt imum Temp. }\end{array}$ & $\begin{array}{l}\mathrm{CH}_{4} \text { for Heating, } \mathrm{CO}_{2} \\
\text { Enrichment, Composted } \\
\text { Sludge and Crop Residues }\end{array}$ & Crop Residues \\
\hline $\begin{array}{l}\text { Open Field́ } \\
\text { Agriculture }\end{array}$ & $\begin{array}{l}\text { Plant Production } \\
\text { (Grain, Vege.) }\end{array}$ & $\begin{array}{l}\text { So il Warming, } \\
\text { Grain Drying }\end{array}$ & $\begin{array}{l}\text { Sludge, Supernatants, } \\
\text { Composted Crop Residues }\end{array}$ & $\begin{array}{l}\text { Crop Residues, } \\
\text { Grain }\end{array}$ \\
\hline $\begin{array}{l}\text { Water } \\
\text { Hyacinths }\end{array}$ & Water Treatment & $\begin{array}{l}\text { Ma intenance of } \\
\text { Opt imum Temp. }\end{array}$ & Organic Wastewater, $\mathrm{CO}_{2}$ & $\begin{array}{l}\text { Feed for Livestock } \\
\text { or Fish }\end{array}$ \\
\hline Algae & Water Treatment & $\begin{array}{l}\text { Maintenance of } \\
\text { Optimum Temp. }\end{array}$ & $\begin{array}{l}\text { All Types of Organic } \\
\text { Wastes, } \mathrm{CO}_{2}\end{array}$ & $\begin{array}{l}\text { Feed for Livestock } \\
\text { or Fish }\end{array}$ \\
\hline $\begin{array}{l}\text { Anaercbic } \\
\text { Digestion }\end{array}$ & $\begin{array}{l}\text { Water Treatment, } \\
\text { Methane Produc. }\end{array}$ & $\begin{array}{l}\text { Maintenance of } \\
\text { Optimum Temp. }\end{array}$ & $\begin{array}{l}\text { All Types of Organic } \\
\text { Wastes }\end{array}$ & $\begin{array}{l}\mathrm{CH}_{4}, \mathrm{CO}_{2}, \\
\text { Supernatant, sludge }\end{array}$ \\
\hline $\begin{array}{l}\text { Sewage } \\
\text { Treatment }\end{array}$ & Water Treatrent & $\begin{array}{l}\text { Maintenance of } \\
\text { Optimum Temp. }\end{array}$ & All Wastes & Supernatant, Sludge \\
\hline
\end{tabular}


residues of drugs and drug metabolites, as well as other contaminants of natural and incustrial origin. Thus, manure refeeding processes generally incorporate techniques to prevent contamination problems. These techniques include drying (natural and heated air), ensiling, chemical treatment, and biological treatment. ${ }^{(19-22)}$ waste heat can also be used to sterilize the manure.

Cattle manure has been used in feeds for cattle, sheep, swine, chickens and catfish. $(18,23-25)$ Both the large fecal output and poor feed conversion ratio of cattle have led to many efforts to utilize cattle manure for refeeding. Usually the manure is mixed with grains or hay. Ruminants have unique digestive capabilities and are particularly wellsuited to refeeding of wastes.

Poultry manure and.litter have also been used as feerd to ruminants. (18,26-29) Feed rations often contain 60 percent or more poultry litter. Its digestible crude protein content is approximately 25 percent, and the metabolizahle energy content averages about $5600 \mathrm{~kJ} /$ kg. $(27,29)$ These values represent about 85 percent of that of good quă lily barley.

Another unconventional livestock feeding involves the feeding of anaerobic digester sludge to swine. ${ }^{(30)}$ The use of various animal manures to grow algae which in turn is used as fish or livestock feed also has been demonstrated. (31)

Refeeding schemes have been incorporated into the energy-agro-waste complexes studied in this project because of their inherent suitability to such systems, demonstrated feasibility, and great potential for maximizing waste utilization. 


\section{Chicken-Cattle-Algae-Digester Complex}

The first system to be developed constituted a chicken-cattle-algaedigester complex. A diagramatic sketch of the solids and energy interrelationships of the complex is presented in Figure 21. As the figure indicates, the three major continuing solids inputs to the system are the supplemented feeds to the chickens and the cattle, and fuel to the power plant. The extent of the feed input, of course, is partly a function of the amount of the wastes generated in the complex and of their suitability as feedstuff to the animals. Note that an egg production operation may be substituted for a broiler production operation with only minor overall effects on the complex. The yield of algae from the algae pond also is a determinant of the amount of feed input that would be needed. In practice, algae could constitute on ly about ten percent of the chicken's total diet without having an adverse effect on egg and meat production. The algae would serve as a prote in supplement for both feeds. Economic and energetic feasibility dictate that sunlight be used as the source of the visible light energy reqired for algae production.

The water needed to set up the system would be that required to serve as an algal culture medium, to dilute the cattle manure to the desired solids level (10 to 15 percent solids), for initial sanitation of the animal quarters, and for drinking water for the livestock. Conceivably, once supplied, an amount equal to only a fraction of that initially supplied would have to be added as makeup water on a continuing bas is since the water would be reclaimed and recycled within the system. For example, effluent from the algae production pond could be used for sanitizing the animals' quarters. The water thus used would be returned to the pond. The wastes picked up in sanitizing would serve as a source of 


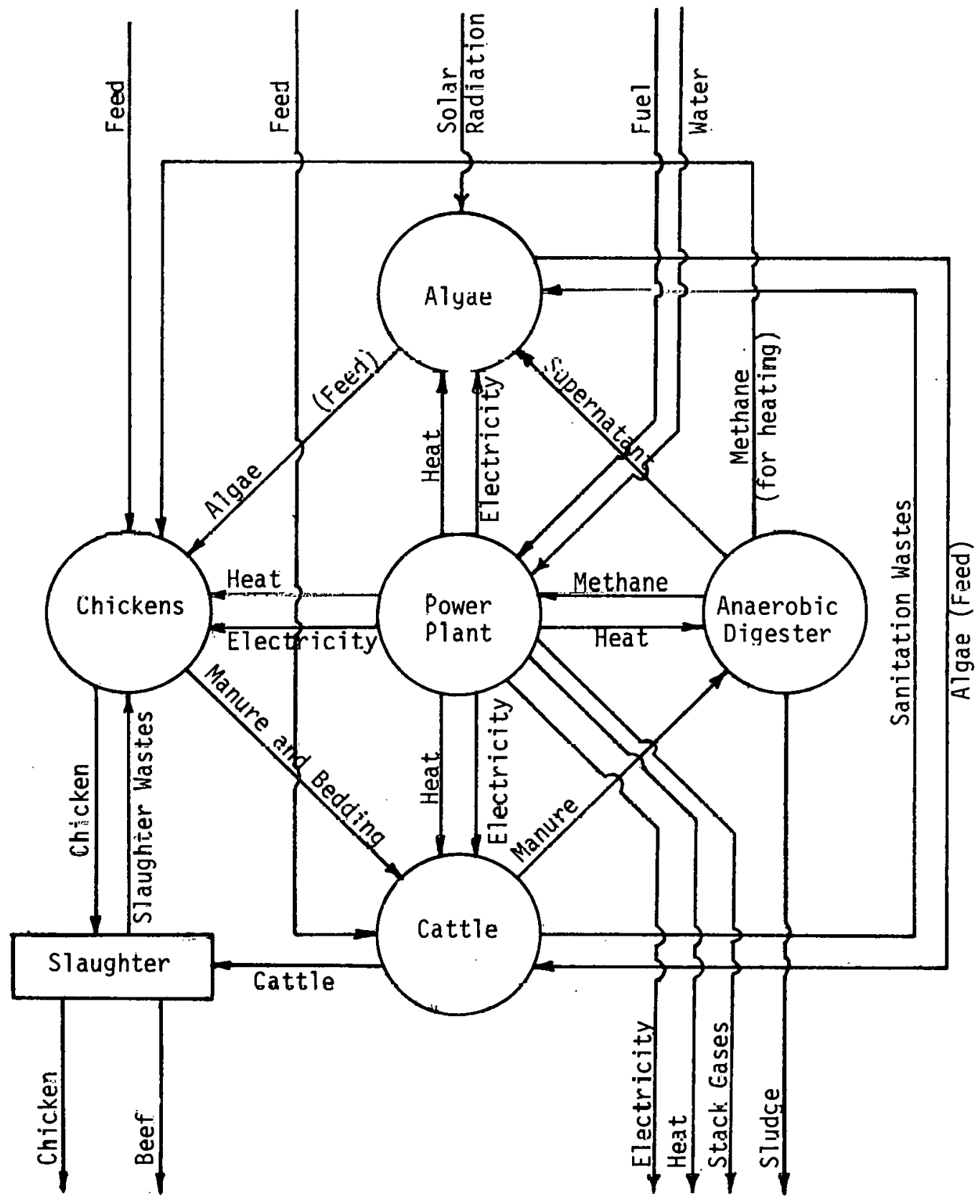

Figure 21. Diagrammatic sketch showing mass and energy interrelationships for a Chicken-Cattle-Algae-Digester Complex. 
nutrients for the algae. Of course, the water components of the system could not be completely closed, both because of loss of water through evaporation and spillage and also because of a salt buildup from the animal wastes and the concentrating effect of evaporation. Although, theoretically, water could be rendered suitable for use as drinking water, in practice it would be better to bring in external drinking water. Drinking water in excess of that imbibed by. the animals could be directed to the algae pond, where it could serve as makeup water. Probably, it would not be advisable to have cooling water from the power plant come into direct contact with the algae, mainly because in conventional practice cooling water is dosed with phytocidal agents to inhibit slime buildup. If no such substances were added to the cooling water, it could be passed through the pond. Another limitation to the introduction of cooling water might be temperature. The alqae usually cultured for high-rate yields have an upper temperature limit of $35-38^{\circ} \mathrm{C}$.

\section{Fish-Chicken-Catt le-Algae-Hyacinth-Digester Complex}

In the second system, two additional processes are introduced, name 1y, fish farming and water hyacinth culture. A diagram of the complex is shown in Figure 22. Aside from the fuel to the power plant, the major continuing solids inputs are feedstuffs to the livestock to compensate for deficiencies in the plant products grown within the system. For example, the hyacinths may lack the carbohydrates and fibrous content required by the cattle and the amino acid complement essential to the chickens. The algae serve as a feedstuff to the tilapia.

The water requirements are much the same as those for the first complex, although in the present system the initial input would be larger to account for the hyacinth pond. Of course, the algae, hyacinths, and 


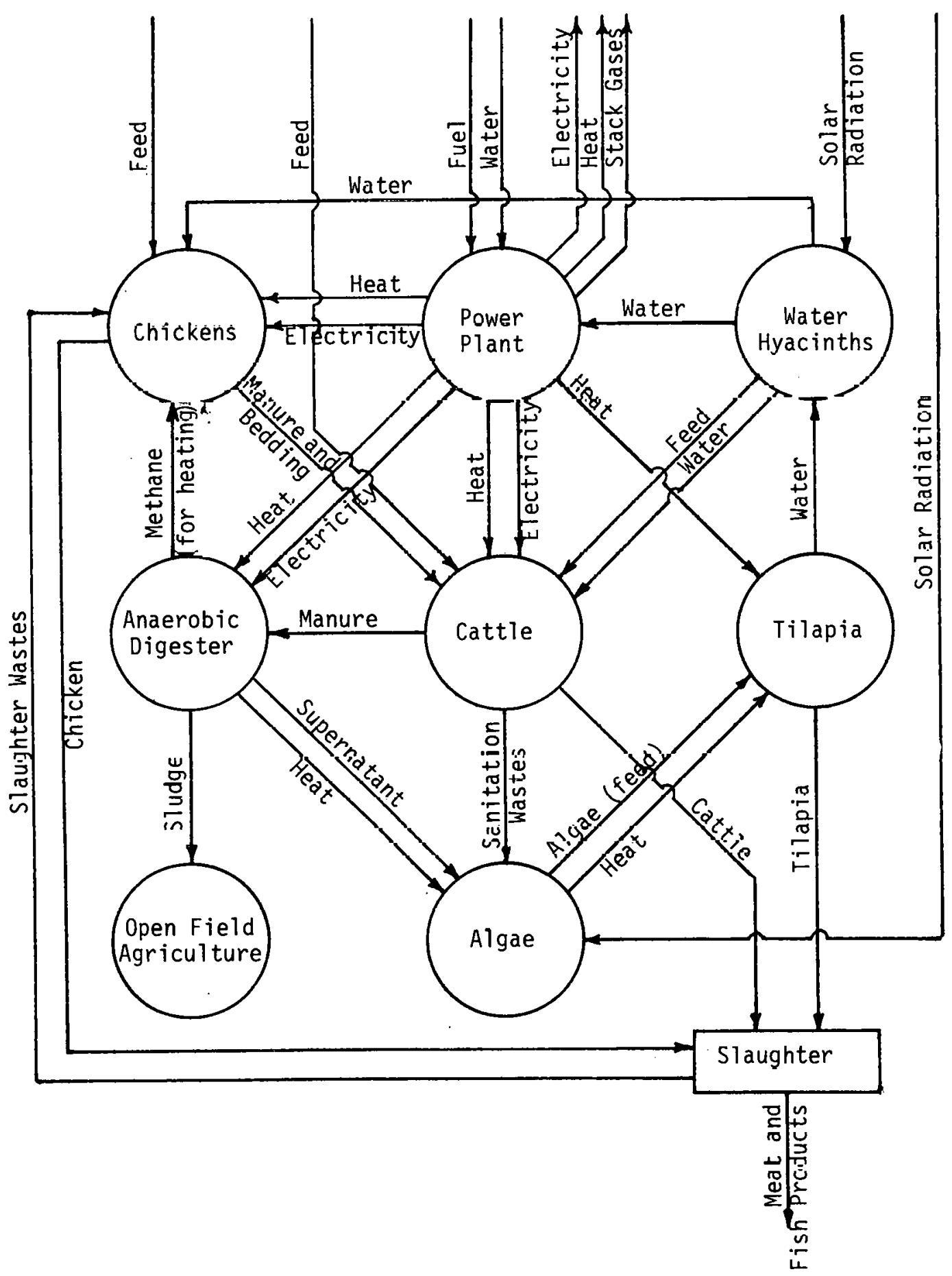

Figure 22. Diagrammatic sketch showing mass and energy interrelationships of a Fish-ChickenCattle-Algae-Hyacinth-Digester Complex. 
fish could be cultured together in one pond. The chances are, however, that by so doing, algae production would be adversely affected due to the shading brought about by the hyacinths. However, the tilapia could be successfully grown with either type of plant (i.e. algae or hyacinth). The constraints on the use of cooling water also apply here.

The anaerobic digester is used to "treat" the manure from the cattle with a subsequent production of methane. The methane is used for heating the chickens, while the sludge can be applied on open fields to recover the nutrients.

The proliferation of subsystems in the complex may have the disadvantage of increasing the chances of toxic intermediate products being generated, i.e., toxic to members of the complex. On the other hand, the introduction of fish culture provides a reliable and effective means of harvesting and simultaneously utilizing the algae. It should be noted that the hyacinths are not the sole agents in "cleaning up" the water, inasmuch as algae also are very effective in that regard.

\section{Fish-Chicken-Catt le-Swine-Algae-Hyacinth Complex}

The complex is diagrammed in Figure 23. As the figure indicates, the differences between the preceding complex and the present complex is that the latter calls for swine production in addition to beef production and eliminates the digester. Although the design diagram for the present complex indicates a cormon unit for the algae, fish, and hyac inth culture, the three could be separated as in the preceding complex. The same arguments, pro and con, hold for both arrangements. An added feed input to the present system would be one to the swine. While it has been dem= onstrated that algae can serve as a sole protein source for swine, they (al.gae) are not utilized as efficiently as is fish meal or other animal 


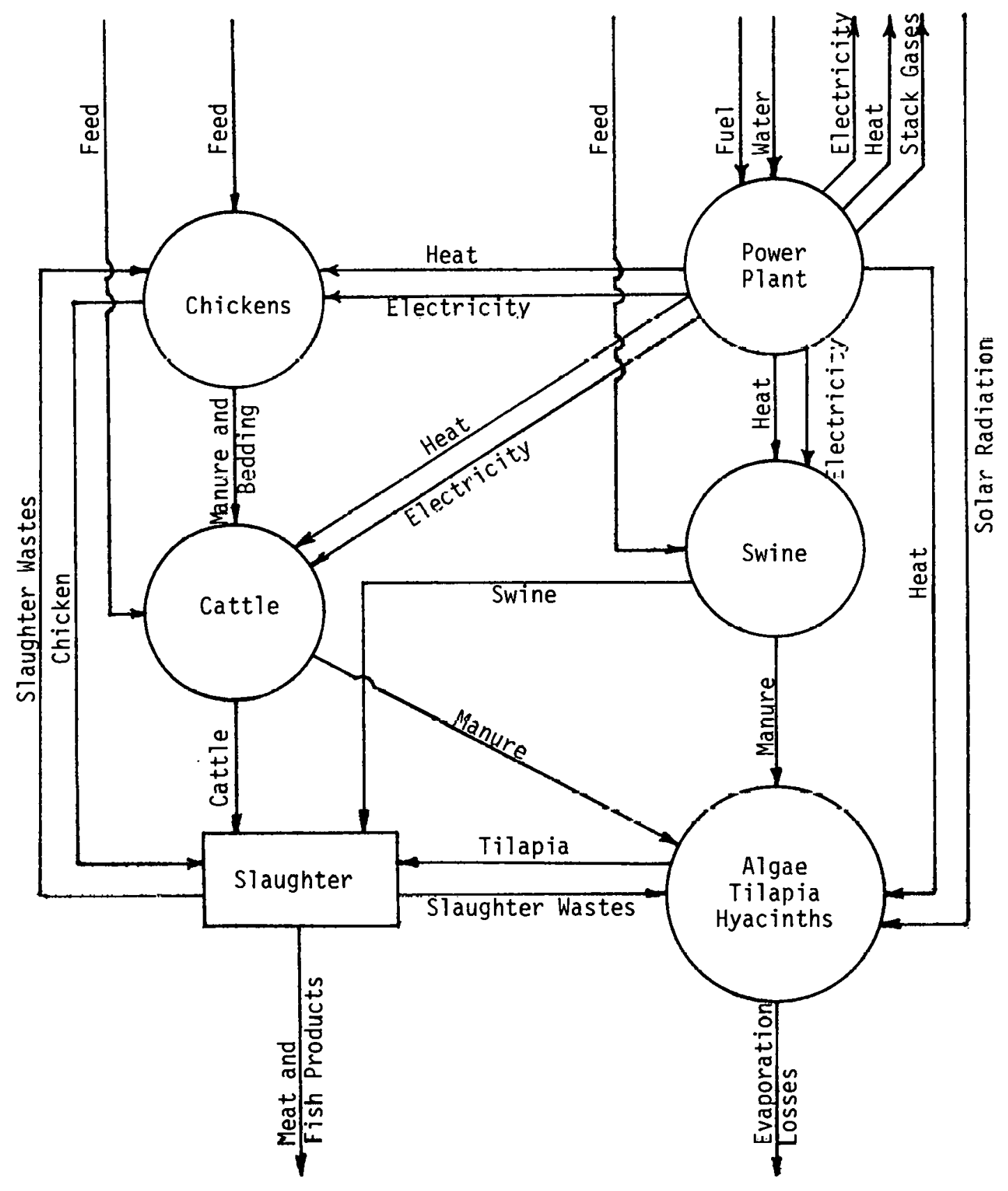

Figure 23. Diagrammatic sketch showing mass and energy interrelationships of a Fish-ChickenCattle-Swine-Algae-Hyacinth Complex. 
protein. Nevertheless, the complex as diagrammed in Figure 23 provides for the algae to be utilized by tilapia. Another variation could be the return of a portion of the slaughter wastes as feed to the swine. In fact, the wastes could provide the protein required by the animals (swine).

With the combined input of wastes from the swine and cattle subsystems, the danger of overloading the algae-fish-hyacinth subsystem could be a very real one. Swine wastes are especially "strong." On the other hand, the fertilizer elements are correspondingly abundant for algae and hyacinth production.

\section{Greenhouse-Open Field-Chicken-Cattle-Digester Complex}

Crop production is expanded from an intra-supporting role with in the complex to one as an output in the present system, as is shown by the diagrammatic sketch of the complex presented in Figure 24. This is done by incorporating a greenhouse and an open field subsystem into a complex, although according to the figure the open field subsystem is, strictly speaking, an "intra-supporting" system since its output goes to the cattle. The water input/output situation is complicated by the inclusion of the open field. The latter brings in uncertainties related to climate, i.e., rainfall, evaporation, wind vclocity, ctc. The net result is that the external input of water would significantly exceed that with the preceding systems. While the presence of the open field may have brought with it an increase in need for external water, it does eliminate the need for an input of feed for the cattle. However, another external input may be required, namely chemical fertilizer clements to make up for an insufficiency of the elements in the sludge, if an insufficiency should exist. 


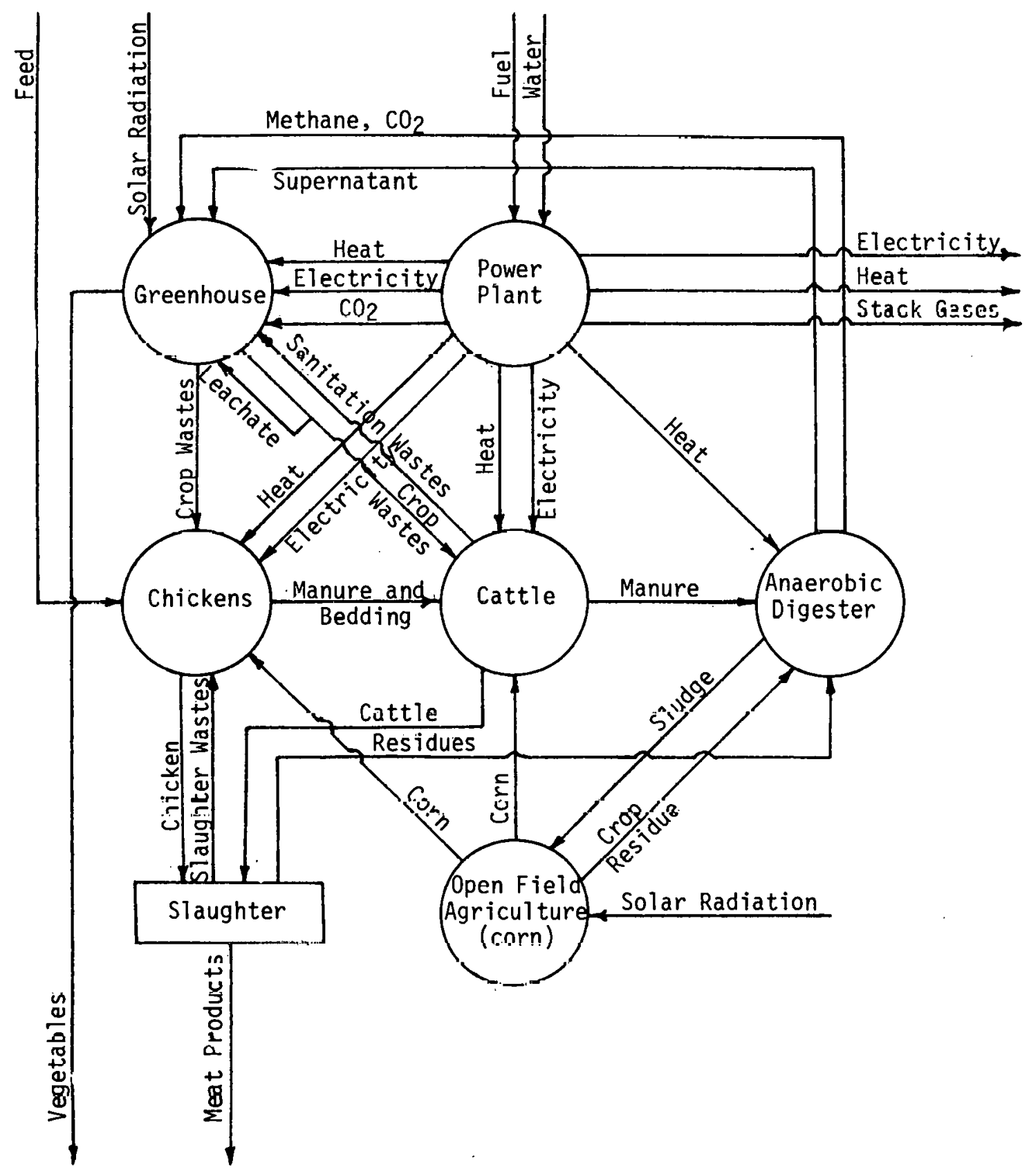

Ftgure 24.- Diagrammatic sketch showing mass and energy interrelationships of a Greenhouse-Open FieldChlcken-Cattle-Digester Complex. 
The advantages accruing from the insertion of an anaerobic digester into the system are: 1 . It serves as a conversion system for crop residues and the wastes from beef production. 2. It is an indirect source of heat energy through its production of the combustible gas, $\mathrm{CH}_{4} \cdot 3$. It also is a source of $\mathrm{CO}_{2}$. Enriching the atmospheric $\mathrm{CO}_{2}$ is demonstrated in daily practice as being beneficial to plant production in greenhouses. Theoretically, it would be advantageous in crop production if the $\mathrm{CO}_{2}$ in the stack gases from the power plant could be diverted to the greenhouse. However, the practical difficulties in so doing would rule out the step for the time being.

\section{Open Field-Cattle-Chicken-Digester Complex}

In this complex, as diagramed in Figure 25, the greenhouse has been eliminated and its (greenhouse) inputs and outputs are diverted to open field crop production. The open field components differ from that in the preceding section in that a sprinkler irrigation system is introduced. The sprinkler irrigation system serves as a partial heat sink for the waste heat from the power plant and the chicken and beef production components. The term "warm" is a more appropriate term for the waters from the latter two components than would be "hot", inasmuch as the temperatures of the waters would be only slightly above that of the amhient. temperatures during warm seasons, and more so during the cold season. of course in addition to its role in heat transport, the water supplies the needed moisture in crop production.

As in the preceding cuiliplex, the digester serves as a treatment device for the wastes from beef production; and its residue, as a snurce of nutrients for crop production in the open field. The differences between the two complexes are: (1) The $\mathrm{CO}_{2}$ from the digester is simply 


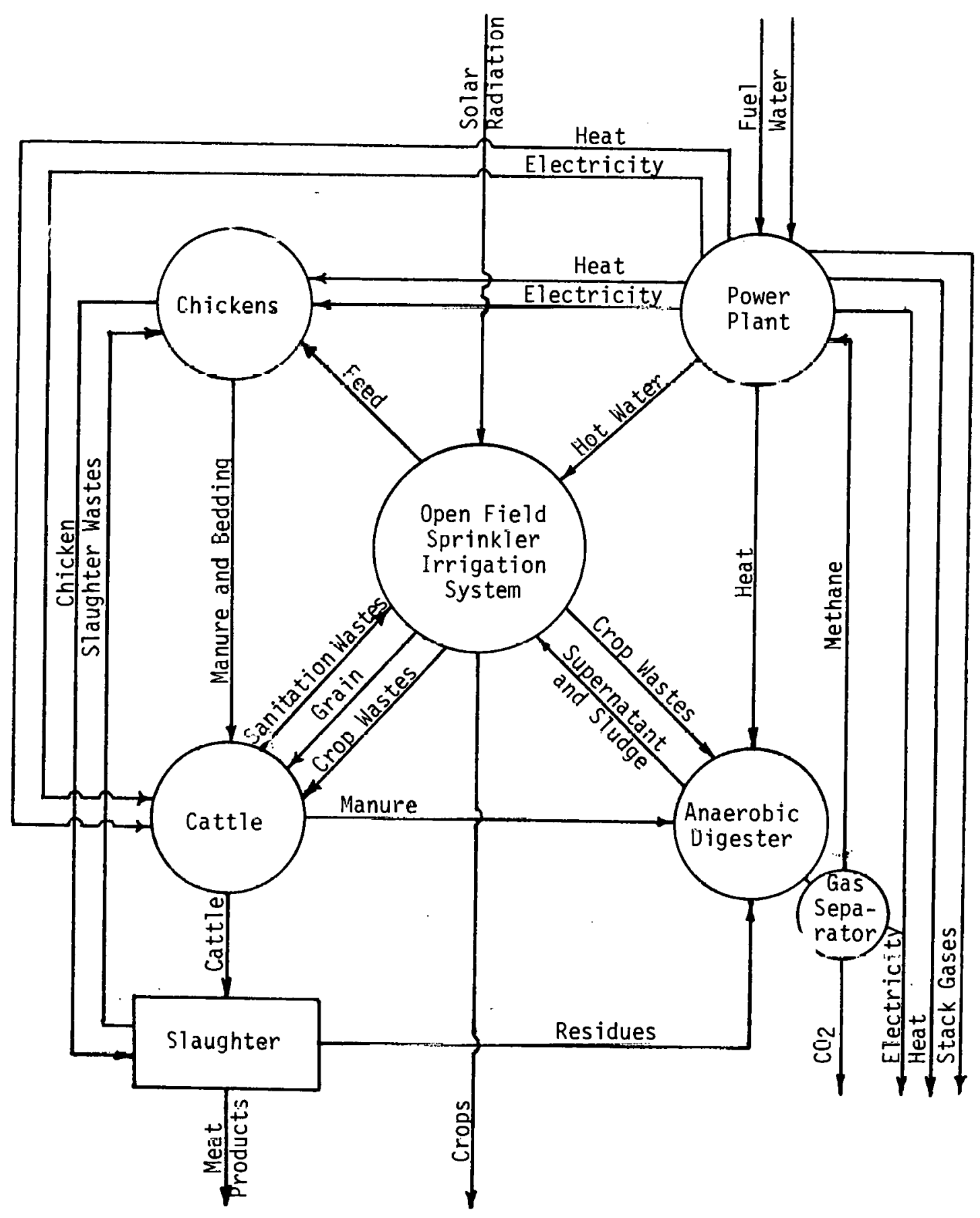

Figure 25. Diagrammatic sketch showing mass and energy interrelationships of an Open FieldCattle-Chicken-Digester Complex. 
wasted to the atmosphere in the present complex, whereas in the preceding complex it was diverted to a greenhouse. (2) The methane is diverted to the power plant, there to be used as a fuel. It should be pointed out that this contribution would be very minute in proportion to the total fuel input to the power plant. Perhaps a better use for the $\mathrm{CH}_{4}$ would be as an energy source for the operation of the beef, chicken, and slaughter facilities. To meet the operational requirements of the power plant, the digester gas would have to be upgraded, i.e. remove the $\mathrm{CO}_{2}$ and objectionable trace gases.

\section{Tree Farm-Cattle-Digester Complex}

The tree farm-cattle-digester complex is diagrammed in Figure 26. In this complex a switch from the agricultural crop production in the preceding complexes is made to forest products production. The inputs to the tree farm are much the same as those to the open field in the preceding complex. For example, the hot water from the power plant serves the dual purpose of heat transport and irrigation with respect to the tree farm.

The digester serves as a treatment device for the wastes from the cattle production, the milling, and the slaughter components. Because of the high $\mathrm{C} / \mathrm{N}$ ratio characteristic of lumbermill wastes, nitrogen normally would have to be added to them before introduction into the digester. However, in the present complex, the nitrogen deficiency of the milling wastes could be made up to an appreciable extent by the nitrogen in the wastes from the beef production and slaughter components. Any remaining nitrogen deficiency would have to be eliminated through the addition of a chemical source, e.g. urea. Ammonia could be added, but only with great caution, since free ammonia is extremely toxic to bacteria. 


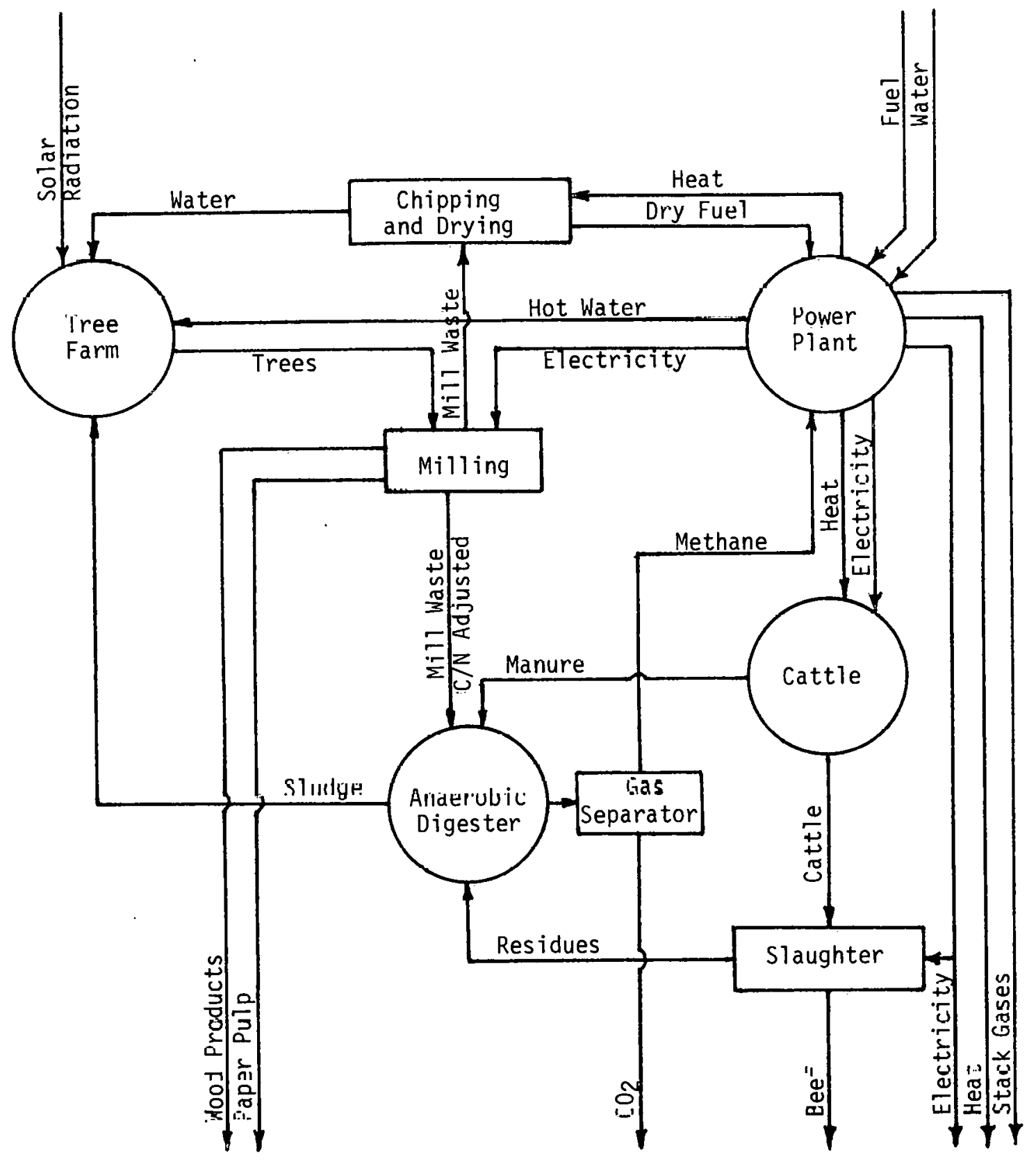

Figure 26. Diagrammatic sketch showing mass and energy interrelationships of a Tree Faril-Cattle-Digester Complex. 
With some modification of the tree farm component, the complex could be used in converting solar energy to biomass. The latter would be digested anerobically to produce methane. With such a modification, the milling component would be eliminated, whereas the chipping component (minus the drying) would be retained. The entire output of methane could be sent to the power plant, or a part could be diverted to other uses.

\section{Greenhouse-Fish-Digester-Recreational Water Complex}

The greenhouse-fish-digester-recreational water complex is diagramed in Figure 27. The present complex is best adapted to the U.S. southeast. The reason is that in the southeastern tier of states, rainfall is of such a magnitude and frequency as to eliminate evapotranspiration as a major means of water removal. Consequently, an effluent is to be expected from the fish production component. Inasmuch as the effluent would be heavily contaminated with fish wastes, it must be treated prior to discharge into the environment. Settleable solids are produced in the primary treatment step (settling basins). Secondary treatment of the wastewaters is accomplished through the establishment of a recreational lake. The extent of the recreational use of the lake depends upon the degree of contamination of the raceways effluent, i.e. of the potential incidence of pathogens. The lake also serves, at least in part, as a source of cooling water for the power plant.

The remaining components of the complex are the greenhouse and the digester. The settled solids from the settling basins are used as a source of plant nutrient and as a component of the soil medium of the greenhouse. Plant debris from the greenhouse serve as input to the anaerobic digester. It is highly problematical that enough residue would be produced to enable a methane production sufficiently great to 


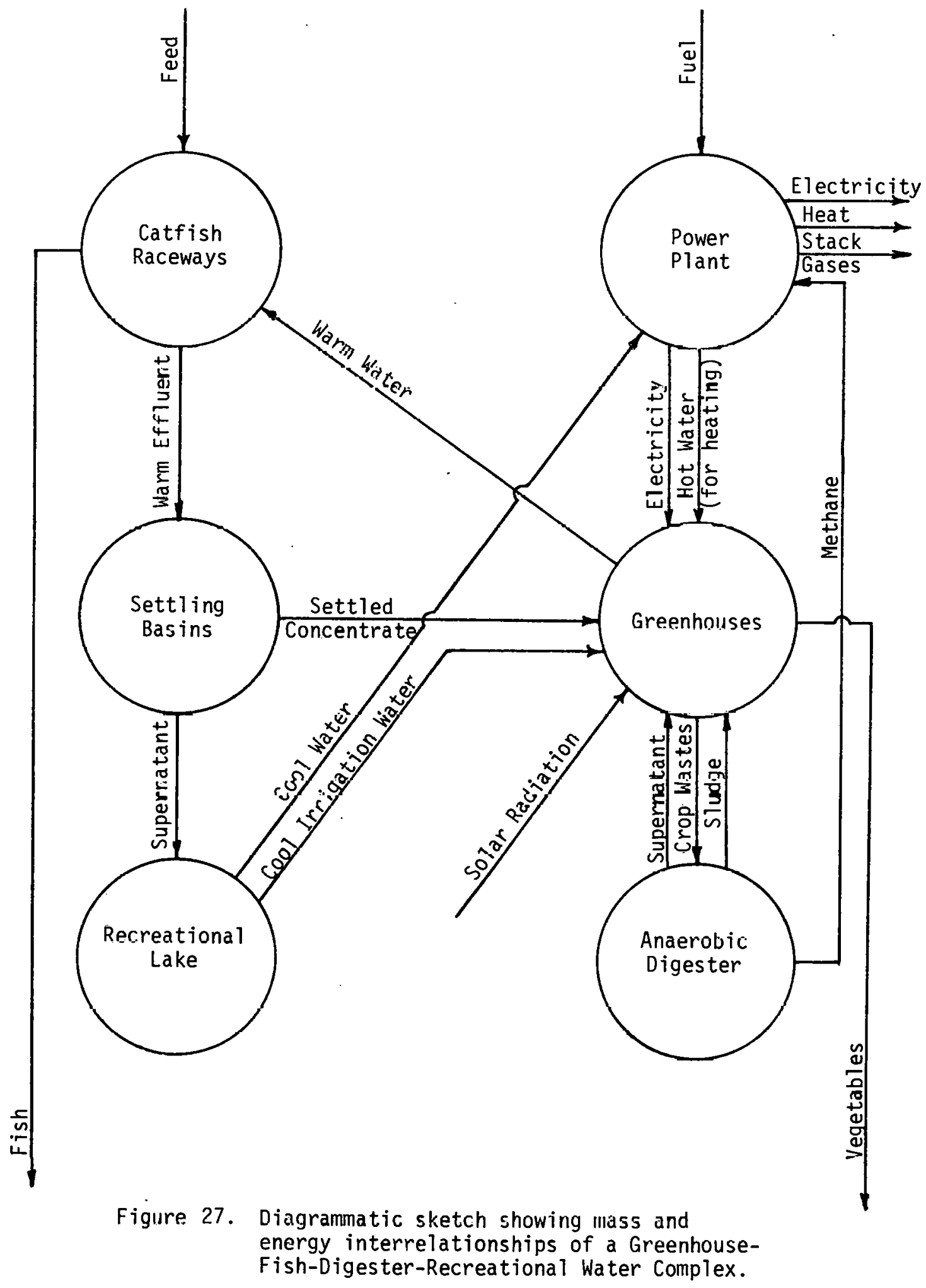


constitute a substantial contribution to the fuel requirements of the power plant.

\section{Sewage-Hyacinth-Digester-Swine-Composting-Open Field Complex}

A rather involved complex is diagrammed in Figure 28 . Its principal elements are sewage treatment, hyac inth production, anaerobic digestion, pork production, a compost operation and open field production of grain. The principal output is pork. Probably, the major feature that distinguishes this complex from others proposed in the present report is the provision for composting the organic fraction of municipal refuse along with the sludge produced in the system's digester. Therefore, its inputs include two major municipal wastes, namely, refuse (garbage and organic rubbish) and sewage. Another important feature is the provision for feeding slaughterhouse wastes and digested sludge to the swine. These characteristics combined with the extensive use of waste heat make this complex a potentially valuable implement for use in resource recovery.

\section{Hyacinth-Cattle Complex}

The water hyacinth-cattle complex diagramed in Figure 29 is another comparatively simple complex in that it consists of only three major components, namely, the ever-present power plant, a cattle production component, and a hyacinth production lagoon.

Plant blomass production in the complex is in the form of water hyacinths. The hyacinth component is the recipient of wastes from the cattle production and slaughter components. Wastes from the latter two must be processed before being introduced into the hyacinth lagoon, mainly to reduce them to a particle size small enough not to interfere with the successful functioning of the lagoon. This processing also calls for the 


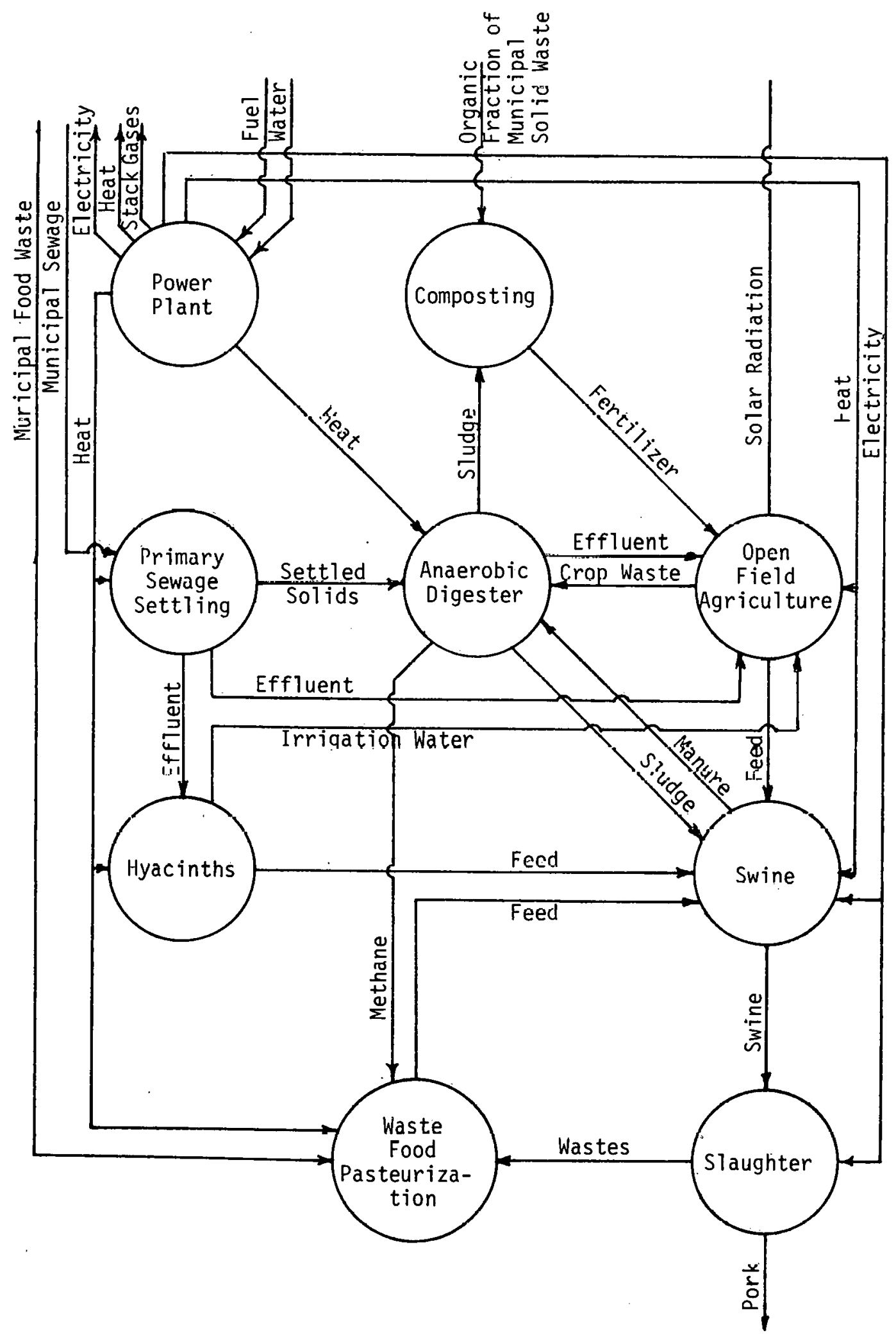

Figure 28. Diagrammatic sketch showing mass and energy interrelationships of a Sewage-HyacinthDigester-Swine-Composting-Open Field Complex. 


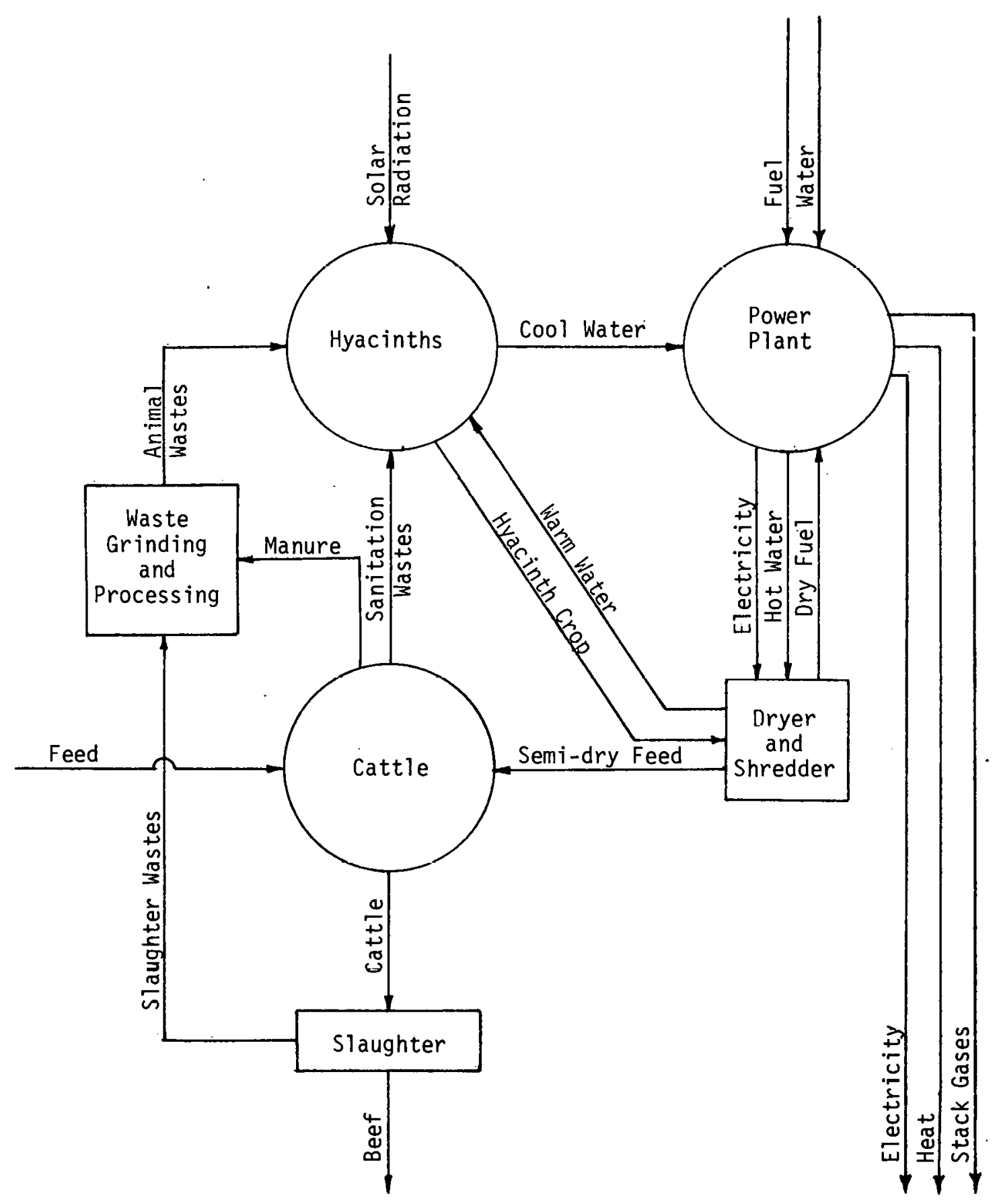

Figure 29. Diagrammatic sketch showing mass and energy interrelationships of a Hyacinth-Cattle Complex. 
suspension of the solids. The fertilizer elements in the wastes serve as nutrients for the hyacinth. By the same token, the hyacinth pond acts as a waste treatment device for the waste output of the two components. Waste heat and electricity from the power plant are used to power the shredder and supply heat to the dryer. The cooling water from the power plant eventually finds its way to the lagoon via the dryer, shredder component. This water serves as makeup water for the lagoon.

The hyacinth production from the lagoon may or may not be great enough to satisfy the nutritional requirements of the livestock. Chances are that it will not. More study is needed on nutritional requirements before firm conclusions on the matter are warranted.

\section{Fish-Open Field Complex}

The fish-open field complex is the simplest of the complexes discussed in the present report. According to the diagram in Figure 30 , its ma in components, in addition to the power plant, are a catfish production facility, a fish-feed factory, and open field qrain and soybean prondurtion. The end products of the complex are fish, grain, and electricity.

The effluent from the fish production component serve hoth as a water source for irrigating the grain fields and as a source of nutrient for the grain crops. It is most likely that an external input to the open fields in the form nf a rhemical fertilizer would be nceded to augment the plant nutrients content in the fish raceways effluent.

It should be noted chat no provision is made for recycling crop res1dues with in the complex.

Those fish processing wastes not found suitable for use in fish production could be used as a source of plant nutrients in the open field production. 


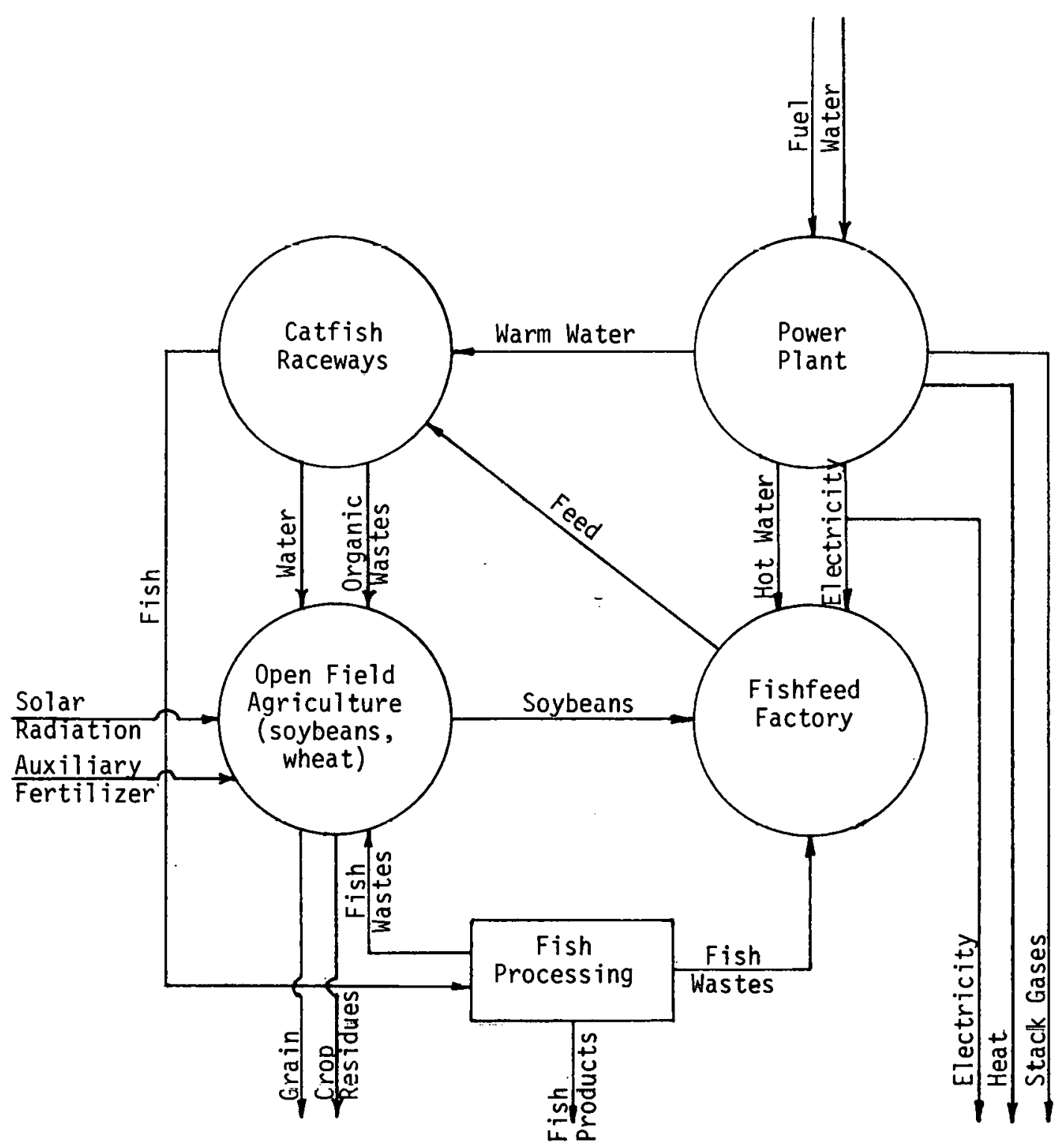

Figure 30. Diagrammatic sketch showing mass and energy interrelationships of a Fish-Open Field Complex. 
Summary Statements on the Potential Complexes

In the course of perusing the preceding descriptions and discussions, the reader may have noticed the absence of a critical discussion on the advantages and disadvantages of the individual complexes. The reason for the failure to include such a discussion is that it would be presumptious without having first arrived at a collective complete material and energy balance of the individual complex as a whole. While it is true that in the preceding section material and to some extent energy balances were made of a number of unft processes, arriving at a collective balance for a complex necessitates integrating and, if necessary, adjusting the balances of its constituent individual components. Another point to be made is that it is highly likely that a provision for auxiliary cooling for the power plant would have to be made in all of the complexes described herein. It also should be emphasized that only the major components and inputs and outputs are included in these diagrams. 


\section{MASS BALANCE ANALYSIS OF INTEGRATED COMPLEXES}

With the completion of a qualitative study of potential integrated systems, several complexes were formed and their mass balances quantitatively analvzed. This was achieved by coupling the unit process models and iterating through the calculations between the different unit processes until acceptable balances were reached. Iterative modifications involved variation in sizing of the unit process operations (e.g., 200 cattle to 100 cattle), addition or depletion of unit processes from the complex being assembled, as we 11 as adjustment of parameter values (with in reported ranges). The complexes for which mass balances are presented here thus may vary somewhat from the complexes qualitatively discussed in the previous chapter.

Due to time and budgetary constraints of this project, four complexes were chosen for detailed analysis with emphasis on mass balances. The four complexes chosen were:

1. Chicken Manure-Digester-Algae-Tilapia Complex

2. Greenhnuse-Catt le-Digester-Open Fie Id Comp lex

3. Chicken-Cattle-Digester-Open Field Complex

4. Sewage-Digester-Hyacinth-Swine-Open Field Complex

A key for explaining the values represented is given for each figure describing the complex. The symbol "TS" stands for total solids, and the symbol "VS" stands for volatile solids. The chemical elements nitrogen, phosphorous, and potassium are denoted by the ir conventional symbols $\mathrm{N}$, 
$P$, and $K$, respectively. Inputs and outputs are given in units of $\mathrm{kg}$ per day. Due to the lack of information on certain parameters, some gaps exist in the figures and some figures vary from others in format. Appendix $D$ contains details concerning the integration of each complex.

\section{Chicken-Digester-Algae-Tilapia Complex}

This system is based in large part upon experiments reported by Dugan, et al. ${ }^{(32-34)}$ The principal additional feature in the proposed scheme is the introduction of tilapia to feed upon the algae. The intrnduction of the fish removes the need for resorting to mechanical or chemical means to remove the algae as is required when the algae are to serve as a feedstuff for livestock.

Conservative estimates based upon feed-to-fish conversion and the experimental production of algae in a suspension of chicken manure indicate that the overall conversion of manure solids to fish is on a modest scale. However, the conversion to fish is not the only productive factor, methane also is produced and recoverable phosphate is precipitated. Although nitrogen recovery should figure strongly in the scheme, a recovery of only about three percent of the manure-N seems likely. A prime reason for the low efficiency in nitrogen recovery is a substantial loss of the element by way of gases evolved from the pond. Most likely, the nitrogen is lost in the form of ammonia.

In the system, chickens are reared as in any large-scale egg production operation, i.e. in cages suspended nver a manure tronugh, but modi= fied somewhat in the manner described by Dugan. Wash-down water for the chicken cages as well as drinking water for the hens are a part of the "closed" system. 
The integrated mass balance for this complex is presented in Figure E1. Some parameter values were adjusted from the unit process models to provide compatibility with other processes. Most of the values used were taken from Dugan, et al. ${ }^{(32-34)}$ A 2:1 feed conversion ratio was used for tilapia on an algae diet.

The operation of the process begins with the removal of the suspended solids from the flushings from the manure troughs by passing the flushings through a settling tank. The supernatant from the tank is discharged directly into the algae pond. The settled solids are subjected to anaerobic digestion with a consequent production of $\mathrm{CH}_{4}$. The effluent slurry from the digester is passed on to the algae pond. (No settled solids are recovered from the digester.) Thus the algae derive their nutrients from two sources, settling tank supernatant and digester effluent. Pond temperature is maintained at an optimum level $\left(25^{\circ}-30^{\circ} \mathrm{C}\right)$ during cold weather through the use of waste heat. Light is assumed not to be a limiting factor. Algal suspension is discharged continuously from the algae pond into the fish production pond (optimum temp. $30^{\circ}-32^{\circ} \mathrm{C}$ ). Fish wastes are sent to the algae pond by way of discharging into the pond the effluent released from the fish pond.

Not taken into consideration in the development of the mass balances were a water balance for bulk correction, metabolic and biochemical water balances, and the eventual fate of phosphorus. Also, salinity buildup would have to be kept down to an acceptable level through the provision of a blowdown.

While not as yet demonstrated experimentally, conceivably phosphate could be recovered by taking advantage of the diurnal rise in $\mathrm{pH}$ leve 1 characteristic of algae production.ponds. The high $\mathrm{pH}$ level triggers the 
precipitation of phosphate complexes. By passing the algal suspension through a special chamber during the time of high pH levels, the rapidly precipitating phosphate could be localized for mechanical recovery. However, no technology for such a recovery presently exists, and the obstacles to the development of one are formidable.

An overall analysis of the complex shows that 1 kilogram of chicken manure input ends up producing 0.074 kilograms of fish meat (wet weight), $0.11 .9 \mathrm{ki}$ lograms of methane, and $0.148 \mathrm{kilograms}$ of $\mathrm{Ca}_{3}\left(\mathrm{PO}_{4}\right)_{2}$. These figures correspond to about 300 chickens and 335 tilapia, roughty $1: 1$.

\section{Greenhouse-Cattle-Digester-Open Field Complex}

The principal input to this system is fertilizer to the greenhouse; and the outputs are vegetables, beef, and methane. Feed for the cattle comes from the open field crops and to a limited extent from cannery wastes and bone meal supplement. The digester serves not only as a source of fertilizer for crop production and of $\mathrm{CH}_{4}$, but also as a treatment device for the animal wastes.

Grccnhousc and digester temperatures dre Illd inlalned throughout the year at an optimum level with waste heat. The open fields are unheated and are sufficiently spacious to accommodate the storage need throughout the year. The tomato cropping is phased such that uniform vine and fruit output continues throughout the year.

The integrated mass balance for this complex is presented in Figure E2. The inputs to the greenhouse are 5.2 tonnes of nitrogen per year, 0.73 tonnes of phosphorus per year, 8.4 tonnes of potassium per year and an unspecified amount of water. Water is also supplied to the digester, the cattle, and the feed crops. Bone meal is supplemented to the cattle 
diet at the rate of 4.6 tonnes per year. The outputs of the complex are 1240 tonnes of tomatoes per year, 38.3 tonnes of beef per year, and 24.8 tonnes of methane per year.

The edible tomato products account for about 67 percent of the influent nitrogen, which leaves only 33 percent to be recovered in the remainder of the complex. The beef production element accounts for 17 percent of the total nitrogen input, although after slaughter, this is reduced to 10 percent. Alfalfa, however, fixes additional nitrogen from the air. Loss of plant nutrients by way of leaching is minimal if the amount of nitrogen is adjusted to that of the nitrogen required by the crop. Phosphorus tends to be immobilized in the top 15 centimeter layer. The soil thus forms a reservoir for phosphorus, the availability of which is quite sensitive to $\mathrm{pH}$. Digester effluent in excess of that required in the open-field crop production can be directed to the greenhouse.

While the integration of the various elements of which it consists is a novel concept, the actual functioning of the individual unit processes as part of the complex does not differ from that in conventional agriculture. The principal exception might be the almost exclusive use of organic wastes to fertilize the open field crops.

The final results of the analysis and calculations lead to the conclusion that a 100-steer (mixed ages) operation would entail the need for a 4-ha greenhouse, a $140 \mathrm{~m}^{3}$ digester, 8.3 ha alfalfa and 13 ha corn. The total area that would be involved in establishing the complex (excluding the power plant) is approximately 26 hectares. 


\section{Chicken-Cattle-Digester-Open Field Complex}

The flow patterns of this complex is completed by the use of chicken manure as supplementary feedstuff for the cattle, the use of slaughter wastes as supplementary feedstuff for both chickens and cattle, the use of digester effluent to irrigate open field crops, running the digester on animal and crop wastes, and feeding both the chickens and cattle with the field grown grain. The slaughter wastes are a source of protein as well as calcium phosphate. Principal inputs to the complex are fertilizer to the fields, water for the animals and irrigation and bone meal supplement for the animals. Principal outputs are chicken and beef products and methane.

Waste heat $c$ an be used to heat the livestock quarters and to maintain the digester at optimum temperature. Undersoil heating is not. used here but also offers potential, particularly in cool or cloudy climates.

Silage would of course be required to distribute the grain supply evenly over the year.

The integrated mass balance for this complex is presented in Figure E3. The fertilizer input to the system is 4.8 tonnes of nitrogen per year, 0.66 tonnes of phosphorus per year, and 3.5 tonnes of potassium per year. Total crop production would be 122 tonnes of corn (grain) per. year, 91 tonnes of alfalfa hay per year, and 9.0 tonnes of sorghum (grain) per year. The corresponding field areas for these crops are 14.4 hectares of corn, 6.7 hectares of alfalfa, and 1.0 hectare of sorghum.

The total meat produrtion of the complex would amount. to 13.1 tonnes of chicken per year and 14.4 tonnes of beef per year. (These are postslaughter figures.) The livestock operations would involve 2750 chickens. and 100 cattle. Feed lo the chickens amounts to 116 kilograms per day 
(42.3 tonnes per year). This daily ration consists of 6 kilograms of slaughter wastes ( 5 percent), 87 kilograms of corn ( 75 percent) and 23 kilograms of sorghum (20 percent). The total weight of rations for the catt le herd is 620 kilograms per day (226 tonnes per year), of which 124 kilograms is in the form of slaughter wastes (20 percent) and $248 \mathrm{kilo-}$ grams (40 percent) each of corn and hay.

The digester volume of $92 \mathrm{~m}^{3}$ is based on an input of $440 \mathrm{~kg}$ solids/day at a 13:1 dilution. Supplemental nitrogen requirements in the digester could be met by diverting a portion of the slaughter wastes into the digester. The determination of the amount of digester effluent required for fertilizing the sorghum and the corn fields is accomplished by assuming a nitrogen loss of 20 percent of the total assimilated by the crop. (This loss indicates the advisability of crop rotation, i.e. with alfalfa.) A summary of data used in arriving at NPK mass balances for the open field crops is given in Tables. B4 and B5.

The fact of losing nitrogen in the soil by leaching is indicative of an accompanying excess of phosphorus and potassium, since the NPK is in a fixed ratio in the digester effluent. The excess phosphorus tends to accumulate in the so11. This phosphorus can be recovered by rotating corn and sorghum with alfalfa. Alfalfa tends to fix nitrogen and thereby paves the way for a further utilization of the phosphorus, at the expense of the accumulated phosphorus. Nutrients not supplied directly in the open field operations may be present as dissolved minerals naturally present in the water used to irrigate the fields. For example, the corn crop would require an addition on ly of $8 \mathrm{ppm}$ in the irrigation water to compensate for the nitrogen deficit. The amount of potassium to be added would only be $3 \mathrm{ppm}$. 
Relying upon a dilution of 13:1 of the feed to the digester (i.e. $4.81 \mathrm{~kg} / \mathrm{m}^{3} /$ day) leads to a digester effluent production equivalent to irrigating at the amount of $0.01 \mathrm{~m}^{3}$ water/year. Additional irrigation would be required in most locations.

The amount of the nitrogen output by way of meat is much smaller than that in the nitrogen input; all nitrogen values for meat are based on the assumption that $N=0.035$ of the total mass or 0.10 of the total solids. The phosphorus content of the meat equals that of the phosphorus 1nput. The concentration of phosphorous for chicken and beef bodies and meat are based on a bone content of 14 percent phosphorus, and that bones constitute 5 percent of chicken carcass and 10 percent of the beef carcass. The value 5 percent is an estimate. The potassium content of the meat is slightly less than the potassium input.

The final results of this analys is leads to the conclusion that a 2750 chicken brood would be compatible with a 100 steer herd, a $92 \mathrm{~m}^{3}$ digester, a 14.4 hectare corn field, a 6.7 hectare alfalfa field, and a 1.0 hectare sorghum field. The total area that would be involved in establishing this complex (excluding the power plant) would be approximately 24 hectares.

\section{Sewage-Digester-Hyacinth-Swine-Open Field Complex}

The interrelationships comprising the Sewage-Digester-Hyacinth-Open Field Complex include the use of sewage treatment effluent for field fertilization and water hyacinth production, the anaerobic digestion of sewage sludge, crop wastes and swine manure, and the feeding of field-grown grain, water hyacinths, slaughter wastes and digested sludge to the swine. The principal input to the complex is raw sewage. The principal outputs are pork and methane. 
Waste heat is used to heat the swine housing and maintain the optimum temperature in the sewage treatment and anaerobic digestion processes. Again, undersoil heating is not used here but does offer added potential use of waste heat.

In the sewage treatment element of the complex, primary and secondary treatment are accomplished. Sludges (raw sludge and activated sludge) are discharged to the digester as in conventional sewage treatment practice. The supernatant (secondary effluent) is discharged in part to a pond to support a water hyacinth crop, and in part to open fields to serve in irrigation. The hyacinth crop serves as a feed supplement in the swine production element. Effluent from the hyac inth pond is used to irrigate the open field. Wastes produced in rearing the swine are discharged into the digester, and the animals eventually are slaughtered. Wastes from the slaughter operation are discharged in part to the animal rearing element for use as a feed supplement, and in part to the digester. A conriection could also be made between the slaughter element. and the sewage treatment facility to indicate the discharge of processing wastewaters to the latter for treatment (i.e. "cleaning up"). The open field receives effluents from the hyacinth pond and the digester. Its output (grain) is fed to the swine in the swine rearing element. Crop residue (stover) is discharged into the digester. From the preceding description, it becomes apparent that the digester is an important element in the waste conversion function of the complex. It has an input from all of the elements with the exception of the water hyacinth pond. Its principal outputs are gases and digested sludge. The gas of importance is methane. Methane would have a greater place of siyniricance in a diagram showing energy relationships. Digester residue (settled solids 
and supernatant) is an important source of plant nutrient for the crops in the open field element.

The integrated mass balance for this complex is presented in Figure E4. It should be noted that in constructing the diagram, not all of the inputs and outputs are included. For example, neither the gas exchange $\left(\mathrm{CO}_{2}, \mathrm{O}_{2}\right)$ at the hyacinth pond/atmosphere interface nor the water losses from the open field by way of evaporation and run-off are indicated, but instead, only those inputs and outputs essential to the continued functioning of the complcx.

The raw sewage input into the complex is 1000 cubic meters per day. Crop production amounts to 1720 kilograms of grain per day 1628 tonnes per year) and 4410 kilograms of water hyacinths per day (1610 tonnes per year), although the latter is composed of 95 percent water. Postslaughter pork yield is 425 kilograms per day (155 tonnes per year).

On a dry weight basis, the daily feed ration to the 1000 swine operation is 2000 kilograms per day. The composition of this ration is 65 kilograms of slaughter wastes per day ( 3 percent), 210 kilograms of digested siudge per day (11 percent), 210 kilograms of water hyac inths per day (11. percent) and equal parts of corn and sorghum, each $760 \mathrm{kilo-}$ grams per day (38 percent).

Because a sizeable share of the nutrient elements (i.e. N, P, K) involved in the animal (swine) element of the complex is contained in the slaughter wastes, it is important that the latter be kept with in the system. This could be done efficiently by using to the extent possible the slaughter wastes as a feed supplment for the swine. An added advantage in so doing is that the nitrogen in the wastes is in the form of amino acids and thus is more efficiently utilized by the animal than it would be in the form of grain. 
The final results of this analysis leads to the conclusion that a 1000 cubic meter per day sewage treatment plant could support 1000 swine. a 36 hectare corn field, a 36 hectare sorghum field, and a 0.84 hectare water hyacinth pond. A 470 cubic meter anaerobic digester would be required in the system. The total area that would be involved in establishing this complex (excluding the power plant) would be approximately 250 hectares. 
CONCLUSIONS

The primary value of the models developed in this work lies in their utility in the engineering analys is of proposed energy-agro-waste complexes. The models provide a guideline for the design of such complexes by determining the sizing of subsystems, the compatibility of subsystems, and the overall feasibility of an integrated complex. This was achieved by the quantification of mass inputs and nutputs of the various unit pro cesses and the subsequent performance of mass balances on the integrated comp lexes.

The inherent difficulty in applying overall mass and energy balances to biological systems is well attested to by anyone who has worked in this field. The problems are greatest when trying to apply these balances to the total body of an animal. This consideration should be kept in mind when reading and using this report. The goal here has been to present the best possible models from information currently available, as well as a useful guide to the analys is of energy-agro-waste complexes (not rigid design formulas).

The wide range of parameter values reported in the literature posed the greatest difficulty in construction of these models. This situation is due to a variety of reasons. Some data reported in the literature were not measured acrurately nor under controlled conditions. Often only one parameter was measured in a study, consequently making it difficult to relate to other parameters. Most parameters involved in this analys is are functions of other parameters, not just constants or even ratios of 
other parameters. For example, feed conversion efficiency is a function of type of feed, ambient temperatures, activity of the animal, and age of the animal. Manure solids content is a function of type of feed, amount of feed, feed conversion efficiency and water intake, as well as a weaker function of other parameters. These problems were reconciled as best as possible by cross-calculations to confirm the values used and preferential use of what we believed to be more reliable publications.

Some parameter values are completely lacking from the literature and thus necessitated assumptions or exclusion from the models. This was particularly common for the fish. Composition of feed, tissue, and manure were frequently unavailable parameters. Further experimental studies would be useful to establish more refined and complete data for most of the animals considered here.

The integrated mass balances were accomplished by an iterative procedure. This involved first making estimates of subsystem sizes and flows and then readjusting to achieve balance of the inputs and outputs for each subsystem. Many iterations are required, and, therefore, th is becomes a tedious process by hand calculation. Computer coding of the unit process models and the integration algorithm would be very beneficial.

Several complexes proved feasible from a mass balance point of view. Other considerations also need to be taken into account, however, such as energy inputs and outputs, engineering design of material transport systems between the subsystems, and operation procedures to ensure a steady year-round distribution of inputs to the appropriate subsystems. Certain processes have a natural interruption of the ir operation, such as slaughter or harvest, but other dependent subsystems cannot have their 
inputs cut off. Various alternatives to avoid this need to be investigated.

The next stage in development of a more comprehensive analytical model should include quantification of energy inputs and outputs to the unit processes and a computer coding of the unit process models and the integration algorithm. 


\section{REFERENCES}

1 Kirk, R.G. "A Review of Recent Developments In Tilapia Culture, With Special Reference To rish Farming In the Heated Effluents of Power Stations." Aquaculture. 1(1):45-60. 1.962.

2 Denzer, H.W. "Studies On The Physiology of Young Tilapia." FAO Fisheries Bulletin. p. 359-366. 1967.

3 Farmanfarmian, A. Integration of Thermal and Food Processing Residuals into a System for Commercial Culture of Freshwater Shrimp. Final Report, Volume III. Prepared for Public Service Electric \& Gas Co. 1976.

4 Willoughby, H., Larsen, H.N., and Bowen, J.T. "The Pollutional Effects of Fish Hatcheries." American Fishes and U.S. Trout News. 17:1-3. 1972 .

5 Stickney, R.R. "The Folyculture Alternative in Aquatic Food Production." Keprinted from Drugs and Food From the Sea, Myth or Reality? University of Ok lahoma Press. Norman, Ok lahoma. 1978.

6 Chimits, P. "Tilapia And Its Culture, A Preliminary Bibliography." FAO Fisheries Bulletin. 8(1):1-33. 1955.

7 0lszewski, M. The Potential Use of Power Plant Reject Heat in Commercial Aquaculture. Oak Ridge National Laboratory Report. 1977.

8 Spector, W.S. Handbook of Biological Data. W.B. Saunders. Philadelphia. 1956.

9 Bardach, J.E. "Husbandry of Aquatic Animals Can Contribute Increasingly To Supplies of High-Grade Prote in Food." Science. 161:10981106. 1968,

10 Jensen, M.H. "The Use of Waste Heat in Agriculture." Proceedings of the National Conference on Waste Heat Utilization. pp. 21-38. 1971.

11. Johnson, H. Greenhouse Cucumber Production. University of California Agriculturat Extension Service. 1975.

12 0lszewski, M., Hillenbrand, S.J., Reed, S.A. Waste Heat vs, Conventional Systems for Greenhouse Environmental Control: An Economic Assessment." Oak Ridge National Laboratory Report. 1976.

13 Tennessee Valley Greenhouse Vegetable Workshop. Tennessee Valley Authority. Chattanooga, Tennessee. 1975. 
14 Ashley, F.C., Hietala, J.S. "The Sherco Greenhouse: A Demonstration of The Beneficial Use of Waste Heat." Proceedings of the Conference on Waste Heat Management and Utilization. Miami Beach. 1977.

15 0lszewski, M. 1977. Power Plant Reject Heat Utilization: An Assessment of the Potential for Wide-Scale Implementation. Oak Ridge Nationa 1 Laboratory Report. 1977.

16 University of California Agricultural Extension Bulletin 2872.

17 Boersma, L., Barlow, E.W.R., Miner, J.R., Phinney, H.K. and 0ldfield, J.E. The Use of Waste Heat in a System for Animal Waste Conversion with By-Product Recovery and Recycling. Water Resources Research Institute. Oregon State University. 1975.

18 Animal Waste Reuse--Nutritive Value and Potential Problems from Feed Add1t 1ves-A Review. Agricultural kesearch Service. USDA. 1971.

19 Day, D.L. and Sweeten, J.M. "Manure Refeeding: Regulations and Equipment Needs." Agricultural Engineering. 60:26-27. 1979.

20 Knight, E.F., McCaskey, T.A., Anthony, W.B. and Walters, J.L. "Microbrial Safety of Fermented Manure-Blended Feed." 71.st Annual Meeting of the American Dairy Science Association. North Carolina State University. Raleigh. 1976.

21 Knight, E.F., McCaskey, T.A., Anthony, W.B. and Walters, J.L. "Microbrial Population Changes and Fermentation Characteristics of Ensiled Bovine Manure--Blended Rations." Journal of Dairy Science. 60:416-423. 1977 .

22 McCaskey, T.A. and Anthony W.B. "Health Aspects of Feeding Animal Waste Conserved in Silage." Proceedings of 3rd International Symposium on Livestock Wastes.

23 Anthony, W.B. "Utilization of Animal Wastes as Feed for Ruminating An imals." National Symposium on Animal Waste Management. Michigan State University. East Lansing. 1966.

24 Anthony, W.B. "Catt.le Manure: Re-Use Through Wastelage Feeding." Proceedings of the Conference on Animal Waste Management. Corne 11 University. Ithaca, New York. 1969.

25 Anthony, W.B. "Feeding Value of Cattle Manure for Cattle." Journal of Animal Science. 30:274-277. 1970.

26 Ray, M.L. and Child, R.D. "Wintering Steers on Boiler House Litter." Arkansas Farm Research, 13(5):3-6. September-October 1964.

27 Verbeek, W.A. "Fowl Manure Is a Valuable Cattle Feed." Farming in S.A. p. 21. June 1960.

28 Hardy, B. "Use Feed Twice--For Chicken Then Cattle!" Farm Journal. pp. 32, 33, 36. March 1965. 
29 "Manure Handling: Danes Try Dried Waste In Feed." Poultry International. pp. 32, 34, 36. September 1975.

30 Diaz, L.F. "Resource Recovery from Pig Manure in the Philippines." In Print. Compost Science/Land Utilization. 1979.

31 Stickney, R.R. \& Hesby, J.H. "Tilapia Production in Ponds Receiving Swine Wastes." Symposium on Culture of Exotic Fishes. Atlanta, Ga. pp. 90-101. January 1978 .

32 Dugan, G.L. Nutrient and Energy Relationships of an Integrated Aerobic-Anaerobic Biosystem. Doctoral Dissertation. University of California at Berkeley.

33 Dugan, G.L., Golueke, C.G., Oswald, W.J. and Rixford, C.E. Photosynthetic Reclamation of Agricultural Solid and Liquid Wastes. Sanitary Engineering Research Laboratoy Report. University of California at Berkeley. 1970.

34 Golueke, C.G., Oswald W.J., Dugan, G.L., Rixford, C.E. and Scher, S. Photosynthetic Reclamation of Agricultural Solid and Liquid Wastes. Sanitary Eng ineering Research Laboratory Report. University of California at Berkeley. 1972.

35 National Academy of Sciences National Research Council. Nutrient Requirements of Domestic Animals: No. 1, Nutrient Requirements of Poultry. Publication 1345. pp. 19-21. 1966.

36 Longhouse, A.D., Hajime, 0., and Ashby, W. "Heat and Moisture Design Data for Poultry Housing." Agricultural Engineering. 41:567-576. 1960.

37 Card, L.E. and Nesheim, W.C. Poultry Production, 10th Edition. Lea \& Febiger. pp. 135-348. 1966.

38 Barrott, H.G. and Pringle, E.M. "Effect of Environment On Growth and Feed and Water Consumption of Chickens." Journal of Nutrition. 41 :25-30. 1949 .

39 Howes, J.R. and Grub, W. "Best Environment for Broiler Production?" Highlights of Agricultural Research. $9(2): 9$. Ayricultural

Experimental Station, Auburn University. Sumer 1962.

40 Beall, S.E. "Conceptual Design of a Food Complex Using Waste Warm Water for Heating." Journal of Environmental Quality. 2(2):207215. 1973.

41 Raghanan, D., ed. Handbook of Manures and Fertilizers. pp. 52-101, 238-243, 290-291, 305. New De Thi. 1964.

42 National Academy of Sciences Natfonal Research Council. Nutrient Requirements of Domestic Animals: No. 4. Nutrient Requirements of Beef Cattle. pp. 2-49. 1976. 
43 Smith, L.A., Grimes, H.W. and Patterson, T.B. "Surmer Grazing and Feed lot Fin ishing of 2-Year-01d Steers." Highlights of Agricultural Research. 8(2):14. Agricultural Experimental Station, Auburn University. Sumner $196 \overline{1} 1$.

44 Kelly, C.F. "Effects of Thermal Environment on Beef Cattle." Agricultural Engineering. pp. 613,614. September 1960 .

45 Anthony, W.B., Harris, R.R., Starling, J.G., Brown, V.L. and Boseck, J.K. "Pelleted Feeds--Promising Method For Improving Beef Production on High Roughage Rations." Highlights of Agricultural Research. $9(1): 3$. Agricultural Experimental Station, Auburn University. Spring 1962.

46 Curry, N.H. "Livestock-Production Plant of the Future." Agricultural Engineering. pp. 619-621. September 1960.

47 Schulz, A.H. "Basic Requirements for Beef Cattle Housing, Feeding and Handling." Agricultural Engineering. pp. 615-617. September 1960.

48 Madewe 11, C.E., Martin, J.B., and Isom, B.G. "Environmental and Economic Aspects of Recycling Livestock Wastes--Algae Production Using Waste Products." Paper presented at Agricultural Economics Section, Association of Southern Agricultural Workers. 1971.

49 Murphy, J.P. and Lipper, R.I. "BOD Production of Channel Catfish." The Progressive Fish-Culturist. pp. 195-198. 1970.

50 Stapleton, H.N. "Future Farmstead Power Requirements." Agricultural Engineering. pp. 622, 632. 1960.

51. National Academy of Sciences National Research Council. Nutrient Requirements of Domestic Animals: No. 2, Nutrient Requirements of Swine. pp. $21=13$. 1.973 .

52 Ross, 0.B. "Swine Housing." Agricultural Engineering. pp. 584-592. 1960.

5.3 Nunrick, F.C. Garbage as Feed for Hogs. Commission of Conservation, Ottawa, Canada. 1918.

54 Loehr, R.C. Pollution Implications of Animal Wastes--A Forward Ortented Review. Office of Research \& Monitoring, U.S. EPA. 13040--07/68. Reprinted June 1973.

55 Gasper, E., Roersma, L. Phinney, H.K., and Miner, J.R. "Ut.ilization of Waste Heat in a Biological System for the Conversion of Swine Manure to Single Cell Prote in and Methane Gas." Presented at 1975 Winter Meeting of American Soc iety of Agricultural Engineers. Chicago, I1linois. December 1975.

56 Tennessee Valley Authority. Utilization of Waste Heat from Power Plants for Aquaculture, Gallatin Catfish Project 1974 Annual Report. 
57 Tennessee Valley Authority. Utilization of Waste Heat from Power Plants for Aquaculture, Gallatin Catfish Project 1973 Annual Report.

58 Lam, E.Y., Odgers, I.L. and Dhillon, G.S. Beneficial Uses of Waste Heat, Final Report. Bechtel Corporation. 1974.

59 Dupree, H.K., "Some Practical Feeding and Management Techniques for Fish Farmers." Proceedings, 1976 Fish Farming Conference and Annual Convention of Catfish Farmers of Texas. pp. 77-83. JuTy 1976.

60 Walker, L.P., and Bakker-Arkema, F.W. "Pond Warming and Fish Culture." Presented at 1975 Annual Meeting American Society of Agricultural Engineers.

61 National Academy of Sciences National Research Council. Nutrient Requirements of Domestic Animals: No. 11, Nutrient Requirements of Trout, Salmon, and Catfish. pp. 1-4. 1973.

62 Parker, N.C. "A Comparison of Intensive Culture Systems." Proceedings of the 1976 Fish Farming Conference and Annual Convention of Catfish Farmers of Texas. pp. 110-120. 1976.

63 Schultink, V.M. and Merva, G. "Waste Heat Utilization from Power Plants in Agriculture, VII--Water Transport." Presented at the 1975 Winter Meeting of American Society of Agricultural Engineers. Chicago, Illinois. December 1975.

64 Yashouv, A. and Halevy, A. "Studies on Growth and Productivity of Tilapia Aureau and Its Hybrid 'Gan Shmuel' in Experimental Ponds At Dor". Bullet in of Fish Culture in Israel. 19(1):16-22. March 1967.

65 She 11, E.W. "Mono-Sex Culture of Male Tilapia Nilotica Linnaeus in Ponds Stocked At Three Rates." FAO Fisheries BuTletin. pp. 353-356. 1967.

66 0lszewski, M. and Wi lson, J.V. "Analysis of Economic and Energy Utilization Aspects for Waste Heat Aquaculture." Proceedings of the Waste Heat Utilization in Aquaculture Workshop II. Rutgers University. New Brunswick, New Jersey. 1978.

67 Pruginin, Y. "The Culture of Carp and Tilapia llybrids In Uganda." FAO Fisheries Bulletin. pp. 224-229. 1967.

68 Symposium On Culture of Exotic Fishes. American Fisheries Society. 1978.

69 Chimits, P. "The Tilapias and Their Culture, A Second Review and Bibliography." FAO Fisheries Bulletin. 9:1-24. 1956.

70 Hickling, C.F. "The Cultivation of Tilapia." Scientific American. pp. 143-152.

71 Easley, J.E. Costs and Returns of Alternative Mountain Trout Production Facilities." Economics Information Report No. 46. North CaroTina State University at Raleigh. 1976. 
72 Eble, A.F. Integration of Thermal and Food Processing Residuals Into A System for Commercial Culture of Freshwater Shrimp, Final Report, Vol. II. Prepared for Public Service Electric \& Gas Co. 1976.

73 Klontz, G.W. "Some Thoughts on How Pollutants Discharged from Fish Hatcheries are Generated." Salmonid. September-October 1977.

74 Public Service Electric and Gas Company. Integration of Thermal and Food Processing Residuals Into A System for Commercial Culture of Freshwater Shrimp, Final Report, Vo 1. I. Prepared for the National Science Foundation. 1977.

75 Beall, S.E. "Waste Heat Uses Cut Thermal Pollution." Mechanical Engineering. pp. 15-20. 1971.

76 Personal rommunication with Hydrafresh Farms. Sall Martin, Calffornia. 1978.

77 Burns, E.R., Pile, R.S., Madewe11, C.E., Martin, J.B. and Carter, J. Using Power Plant Discharge Water In Controlled Environment Greenhouses, Progress Report II. Tennessee Valley Authority. December 1976.

78 Rykbost, K.A. and Boersma, L. Soil and Air Temperature Changes Induced by Subsurface Line Heat Sources. Special Report 401. Oregon State University Agricultural Experiment Station, Corvallis. December 1973.

79 California Crop Report Service. 1973.

80 Communication from R.V. Stansfield, Northern States Power Company. 1978.

81 Aldrich, S.R. and Leng, E.R. Modern Corn Production. F\&W Publishing Corp. p. 299. 1065.

82 Wolverton, B.C. and MCDonald, R.C. "Water Hyacinths For Upgrading Sewage Lagoons To Meet Advanced Wastewater Treatment Standards: Part II." Compiled Data On The Vascular Aquatic Plant Program: 1975-1977, Section I. pp. 19-42. 1976.

83 Livestock Waste Management and Pollution Abatcment. Proceedings of the International Symposium on Livestock Wastes. Ohio State University。 Columbus. 1971.

84 Oswald, W.J. "Produrtivity of Algae in Scwage Dizposal." Sular. Energy. 15:107-117. 1973.

85 Boersma, L., Barlow, E.W.R., Miner, J.R., and Phinney, H.K. Animal Waste Conversion Systems Based on Thermal Discharges. Special Report 416. Oregon State University. 1974. 
APPENOIX A

The tables concerning input and output data of animal production were constructed as follows. A general format of input and output information was used to provide ease of comparison, although the same type of information in each category varies due to applicability and availability. Input data were categorized into assumptions, feed, water intake and environmental requirements. Output data were categorized into metabolism and tissue production, solid wastes, water losses and heat losses. Values are given on a per animal basis and generally as lifetime averages. In certain cases, ranges of reported values in the literature are presented. Reference sources are indicated in the right hand column. Where reference numbers do not appear, data have been derived from calculations using other data in the table. 
(GE) Gross Energy (bomb calorimeter combustion)

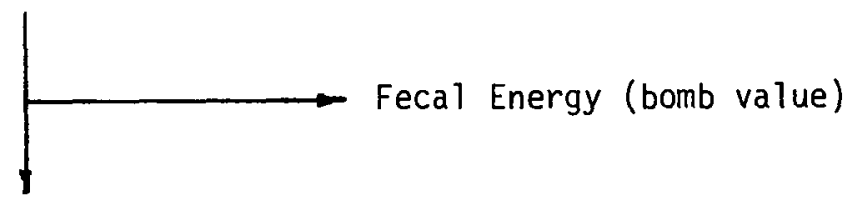

(DC) nigestible Energy (absorbed by system)

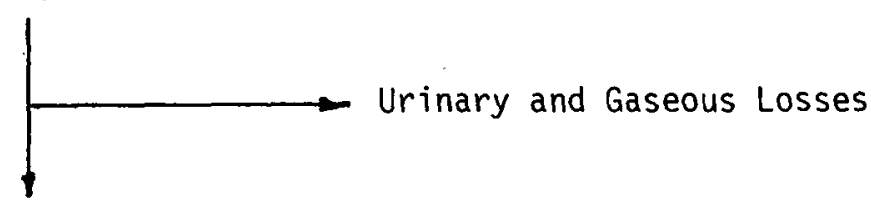

(ME) Metabolizable Energy'

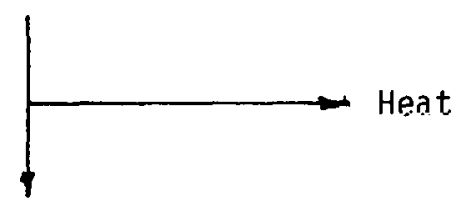

(NE) Net Energy

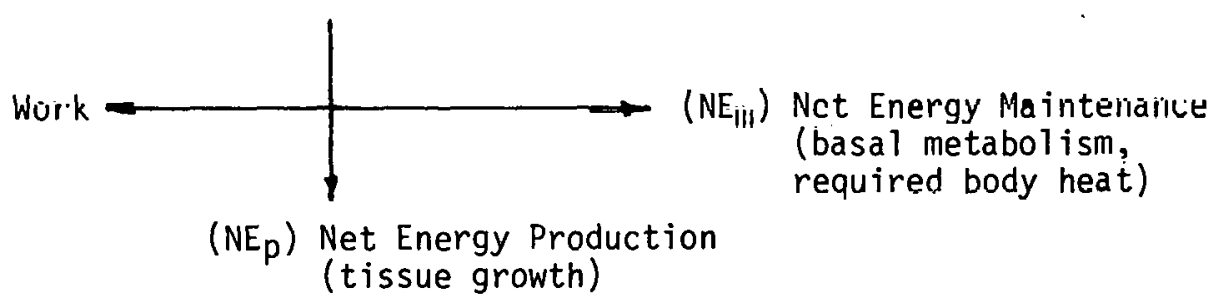

Figure A-1. Terminology pertaining to energy in animal. nutrition. 
Table A1

Innut Data Regarding Chicken Production

1. Assumptions:
a. Growth time and weight at slaughter $=10$ to 13 weeks, 1.5 to $2.0 \mathrm{~kg}$
b. Animal body temperature $=41^{\circ} \mathrm{C}$
c. Chicken house temperature $=250 \mathrm{C}$
d. Data taken for White Leghorn variety

2. Feed:
a. Feed to weight gain ratio $=2.5$ to $3: 1$
b. Daily consumption $=6 \%$ to $10 \%$ of body weight./day, lifet ime average $=0.05 \mathrm{~kg} / \mathrm{day}$
c. Solid fraction in feed $=0.90(0.045 \mathrm{~kg} /$ day $)$
d. Metabolizable water fraction in feed $=0.54$ $(0.027 \mathrm{~kg} /$ day $)$
e. Metabolizable energy content of feed $=$ $1.26 \times 3.0^{4} \mathrm{~kJ} / \mathrm{kg}(7.27$ Watts tot.a 1$)$
f. Composition: Protein $=22 \%$ to $24 \%(9,200$ to 13,800 $\mathrm{kJ} / \mathrm{kg}$; Fats $=2 \%$ to $5 \%(32,300$ to $36,900 \mathrm{~kJ} / \mathrm{kg})$

$(35,36)$

3. Water Intake:

a. Water to feed ratio $=2.4: 1(0.1 .2 \mathrm{~kg} /$ day $)$

4. Environmental Requirements:
a. Ambient temperature comfort zone $=35^{\circ} \mathrm{C}$ initially, decreasing linearly to $190 \mathrm{C}$ on 32nd day. Adult.s maintained between $15^{\circ} \mathrm{C}$ and $25^{\circ} \mathrm{C}$
b. Relative humidity $=60 \%$ to $85 \%$
c. Heat input in cold weather $\left(-18^{\circ} \mathrm{C}\right)$, approximately 0.15 to $0.30 \mathrm{~kW} / \mathrm{m}^{2}$
d. Ventilation $=0.3$ to 0.3 1iters $/ \mathrm{scc} / \mathrm{kg}$ animal $(16-48 \mathrm{~kW} / \mathrm{ha})$
e. Illumination $=110 \mathrm{~kW} / \mathrm{ha}$ average
f. Space $=0 . ?$ to $0.3 \mathrm{~m}^{2} /$ animal 
Table A2

Output Data Regarding Chicken Production

1. Metabolism and Tissue Production:

a. Stored tissue $=0.019 \mathrm{~kg} /$ day (average)

b. Moisture fraction of tissue $=0.70$

c. Stored water $=0.135 \mathrm{~kg} /$ day

d. Stored solids $=0.0 n 58 \mathrm{~kg} / \mathrm{day}$

ค. Energy content of tissue $=6280 \mathrm{~kJ} / \mathrm{kg}$

f. Stored tissue enerqy $=1.40$ watts

a. Enerqy requirements for metabolism $=20.9$ $\mathrm{kJ} / \mathrm{liter} \mathrm{O}_{2}$ consumed

h. Metabolic energy = Feed energy - Stored tissue energy $=5.87$ Watts

i. $0_{2}$ consumption $=24.3$ liters $/$ day $=0.032 \mathrm{~kg} /$ day

j. Respiratory quotient $=0.8$

k. $\mathrm{CO}_{2}$ metabolic production $=19.4$ liters/day $\because 0.036 \mathrm{~kg} / \mathrm{day}$

1. Total broiler production $=3,0 \times 10^{5} \mathrm{~kg} / \mathrm{ha} / \mathrm{ye}$ ar

2. Solid Wastes:

a. $\quad$ Total manure $=($ Feed + Water intake $) / 1.8$

L. Sulld fraction of manure $=0.23(0.022 \mathrm{~kg} /$ day $)$

c. Fecal solids from mass balance $=$ Feed solids stored snlids - metabolic loses - 0.045 - 0.0050 $0.013=0.0 ? 6 \mathrm{~kg} / \mathrm{Hay}$

d. Manure composition:

$11 \%=57 \%$ lu $80 \%$ (fresh), $16 \%$ (air-dried)

Protein (crude) $=25 \%$ (dry. weight)

Nitrogen $=4 \%$ to $6 \%$ (dry weight)

$\mathrm{P}_{2} \mathrm{O}_{5}=1.17 \%$ (at $57 \%$ mo isture content)

$\mathrm{K}_{2} \mathrm{O}=0.62 \%$ (at $57 \%$ mo isture content) 
Table A2 (continued)

e: Nitrogen loss as ammonia in air $=0.007 \mathrm{~kg} / \mathrm{day}$ (assuming $50 \mathrm{ppm}$ )

f. Litter change with each brood $=0.1 \mathrm{~m}$ deep $=$

$13 \mathrm{~kg} / \mathrm{m}^{2}$ saw wastes $=0.022 \mathrm{~kg}$ litter per bird per day

3. Water Losses:

a. Water fraction of manure $=0.77$

b. Water content of manure $=0.062 \mathrm{~kg} / \mathrm{day}$

c. Respired water to water intake ratio $=0.43: 1$

d. Respiratory losses $=0.068 \mathrm{~kg} /$ day

e. Water balance: Water intake + Metabolic water Stored water - Fecal water - Respired water = $0.12+0.027-0.0135-0.062-0.068=0.00$

4. Heat Losses:

a. Body heat loss $=9.0$ to $1.5 .5 \mathrm{~W} / \mathrm{kg}$ at $15^{\circ} \mathrm{C}$

b. Latent heat loss $=1.9 \mathrm{~W}$ 
Table A3

Input Uata Regarding Beef Production

1. Assumptions:

a. Growth time and weight at slaughter $=2$ years, $500 \mathrm{~kg}$

b. Animal body temperature $=400 \mathrm{C}$

(:. Amhtent temperature $=16^{\circ} \mathrm{C}$

2. Feed:

a. Feed to weight gain ratio $=7.5: 1$ to $12: 1$, lifetime average $=9: 1$

$(42,46,47)$

h. Daily consumption $=1.4 \%$ to $3 \%$ of body weight $/$ day, lifetime average $=6.2 \mathrm{~kg} /$ day

c. Solid fraction in feed $=0.9(5.58 \mathrm{~kg} /$ day $)$

d. Metabolizable water fraction in feed $=0.54$ (3.34 kg/day)

e. Metabolizable energy content of feed $=1.00 \times 10^{4}$ $\mathrm{kJ} / \mathrm{kg}$ (721 Watts total)

3. Water Intake:

a. Water to feed ratio: $3: 1$ at $5^{0} \mathrm{C}$ and $8: 1$ at $32^{\circ} \mathrm{C}$ (average $31.0 \mathrm{~kg} /$ day)

4. Environmental Requirements:

a. Ambient temperature comfort zone $=-50 \mathrm{C}$ to $25^{\circ} \mathrm{C}$ (as sume $15^{\circ} \mathrm{C}$ )

b. Ventilation (in enclosure) $=24$ liters $/ \mathrm{sec} /$ anima 1

C. Space $=6 \mathrm{~m}^{2} /$ anima 1 
Table A4

Output Data Regarding Beef Production

1. Metabolism and Tissue Production:

a. Stored tissue $=0.68 \mathrm{~kg} /$ day (average)

b. Moisture fraction of tissue $=0.68$

c. Stored water $=0.46 \mathrm{~kg} / \mathrm{day}$

d. Stored solids $=0.22 \mathrm{~kg} /$ day

e. Energy content of tissue $=8770 \mathrm{~kJ} / \mathrm{kg}$

f. Stored tissue energy $=69.5$ Watts

g. Energy requirements for metabolism $=20.1 \mathrm{~kJ} / \mathrm{liter}$ $\mathrm{O}_{2}$ consumed

h. Metabolic energy = Feed energy - Stored tissue energy $=652$ Watts

i. $\mathrm{O}_{2}$ consumption $=2800$ i iters $/$ day $=3.7 \mathrm{~kg} /$ day

j. Respiratory quotient $=0.8$

k. $\mathrm{CO}_{2}$ metabolic production $=22401$ iters $/$ day $=$ 4.I kg/day

2. Solid Wastes:

a. Total manure $=9$ to $25 \mathrm{~kg} /$ day

b. Solid fraction of manure $=0: 18$

c. Fecal solids from mass balance $=$ Feed solids stored solids - metabolic losses $=5.58-0.22$ $-1.43=3.93 \mathrm{~kg} / \mathrm{day}$

d. Slaughter composition (no bones): Nitrogen $=8 \%$ to $10 \% ; \mathrm{P}_{2} \mathrm{O}_{5}=3 \% ; \mathrm{B} .0 . \mathrm{D} .=0.102 \%$ of live weight

e. Bonemeal: $\mathrm{N}=3 \% \quad \mathrm{P}_{2} \mathrm{O}_{5}=20 \%$ (only $8 \%$ available)

3. Water Losses:

a. Water fraction of manure $=0.82$

b. Water content of manure $=17.9 \mathrm{~kg} /$ day 
Table A4 (continued)

c. Urine to feces ratio $=0.22: 1$ to $0.65: 1$ (assume $0.4: 1$ )

d. Respiratory losses $=7.1 \mathrm{~kg} /$ day

e. Water balance: Water intake + Metabolic water Stored water - Fecal water - Urine - Respired water $=31.0+3.3-0.5-17.9-8.8-7.1=0.0$

4. Heal Losses:

a. Butly hert. luss $=2.2 \mathrm{~W} / \mathrm{kg}$ at $200 \mathrm{~kg}, 1.4 \mathrm{~W} / \mathrm{kg}$ at

b. Latent heat $105 s=25 \%$ to $50 \%$ of total heat loss at $15^{\circ} \mathrm{C}$ to $25^{\circ} \mathrm{C}$

c. Latent heat loss $=200 \mathrm{~W}$ 
Table A5

Input Data Regarding Pork Production

1. Assumptions:

a. Animal body temperature $=380 \mathrm{C}$ to $39^{\circ} \mathrm{C}$

b. Amb ient temperature $=150 \mathrm{C}$

2. Feed:

a. Feed to weight gain ratio $=2.6$ to $4.2: 1$ (average $3.5: 1)$

b. Daily consumption $=9 \%$ to $3.3 \%$ of body weight $/$ day (declines with maturity), lifetime average = $2.2 \mathrm{~kg} / \mathrm{day}$

c. Solid fraction in feed $=0.9(2.0 \mathrm{~kg} /$ day $)$

d. Metabolizable water fraction in feed $=0.54$ $(1.2 \mathrm{~kg} / \mathrm{day})$

e. Metabolizable energy content of feed $=12,600$ $\mathrm{kJ} / \mathrm{kg}$ ( 318 Watts tota 1 )

f. $\quad$ Crude protein content $=22 \%$ to $13 \%$ (declines with maturity)

f. Recyclable waste feed:

Poultry manure $=15 \%$ of ration Garbage $=6$ to $9 \mathrm{~kg} / 100 \mathrm{~kg}$ anima $\mathrm{l}$

3. Water Intake:

a. Water to feed ratio $=1.8: 1 .(3.96 \mathrm{~kg} /$ day $)$

4. Environmental Requirements:

a. Ambient temperature comfort zone $=18^{\circ} \mathrm{C}$ to $23^{\circ} \mathrm{C}$

b. Heat, input capability $=0.12 \mathrm{~kW} / \mathrm{m}^{2}$

c. Electrical input (mechanical, lighting) =

d. Illumination minimal

e. Space $=2.3 \mathrm{~m}^{2} /$ antmal 
Table A6

Output Vata Kegarding Pork Production

1. Metabolism and Tissue Production:
a. Stored tissue $=0.63 \mathrm{~kg} /$ day (1 ifetime average)
b. Moisture fraction of tissue $=0.65$
c. Stored water $=0.41 \mathrm{~kg} / \mathrm{day}$
d. Stored solids $=0.22 \mathrm{~kg} /$ day
e. Energy content of tissue $=10,500 \mathrm{~kJ} / \mathrm{kg}$
$f$. Slured ticeue energy $=76.3$ Watts
g. Energy requirements for metabolism $=20.1 \mathrm{~kJ} / 1$ iter $\mathrm{O}_{2}$ consumed
h. Metabolic energy = Feed energy - Stored tissue energy $=24$ ? Watts
i. 0 ? consumption $=1040$ liters $/$ day $=1.4 \mathrm{~kg} /$ day
j. Respiratory quotient $=0.8$
k. $\mathrm{CO}_{2}$ metabolic production $=832$ liters $/$ day $=$ $1.5 \mathrm{~kg} / \mathrm{day}$

2. Solid Wastes:
a. Total manure $=2 \%$ to $10 \%$ of body weight. per day
b. Sntid fraction of manure $=0.19$
c. Fecal solids from mass balance = Fecal solids - Stored solids - Metabolic losses $=2.0-0.2-0.5$ $=1.3 \mathrm{~kg} /$ day

$(52,54,55)$

d. Manure composition:

$\mathrm{H}>\mathrm{O}=75 \%$ to $85 \%$

Organic matter $=17 \%$ (wet weight)

Nitrogen $=0.2 \%$ to $0.9 \%$ (dry weight)

$\mathrm{P}_{2} \mathrm{O}_{5}-0.14 \%$ to $0.83 \%$ (dry weight)

(8)

$K_{.2} O^{5}=0.18 \%$ to $0.5 ? \%$ (dry weight)

$(41,5 n, 55)$

e. Slaughter composition (no bones):

Nitrogen $=8 \%$ to $10 \% ; \mathrm{P}_{2} \mathrm{O}_{5}=3 \% ; \mathrm{B} .0 . \mathrm{D} .=0.32 \%$

of live weight

f. Manure to $N-f i x i n g$ a lgae production ratio $=5.4: 1$, non $N$-fixing algae ratio $=16.3: 1$ 
Table A6 (continued)

3. Water Losses:

a. Water fraction of manure $=0.81$

b. Water content of manure $=1.05 \mathrm{~kg} /$ day

c. Urine to feces ratio $=1.2: 1$

d. Urine loss $=1.26 \mathrm{~kg} /$ day

e. Respiratory losses $=3.5 \%$ of body weight $/$ day $(2.4 \mathrm{~kg} /$ day $)$

f. Water balance: Water intake + Metabolic water Stored water - Fecal water - Urine - Respired water $=$ $4.0+1.2-0.4-1.1-1.3-2.4=0.0$

4. Heat Losses:

a. Body heat loss for $57 \mathrm{~kg}$ anima 1, loosely confined $=117$ Watts sensible, 62 Watts latent at $10^{\circ} \mathrm{C}$

$=94$ Watts sensible, 73 Watts latent at $200 \mathrm{C}$

$=53$ Watts sensible, 94 Watts latent at $30^{\circ} \mathrm{C}$

b. Body heat loss for $57 \mathrm{~kg}$ an imal, tightly confined $=108$ Watts sensible, 67 Watts latent at $10^{\circ} \mathrm{C}$

$=70$ Watts sensible, 82 Watts latent at $200 \mathrm{C}$

$=6$ Watts sensible, 117 Watts latent at $300 \mathrm{C}$

c. Heat loss per unit surface area $=625 \mathrm{~W} / \mathrm{m}^{2}$ 


\section{Tăhle A7}

Input Vata Regarding Catfish Production

1. Assumptions:

a. Raceway culture

b. Fingerling stocking $=50$ to $90 \mathrm{~kg} / \mathrm{m}^{3} / \mathrm{yr}$

c. Average harvestable size $=0.5 \mathrm{~kg}$ ( $c$ an be grown

2. Feed:

a. Feed to weight ga in ratio $=1.3$ to $3.3: 1$, best cunver'sion rates at opt imum water temperatures

b. Daily consumption $=1.8 \%$ to $6 \%$ of body weight/ day (1 ifet ime average $=0.005 \mathrm{~kg} /$ day)

c. Metabolizable energy in feed $=12,100 \mathrm{~kJ} / \mathrm{kg}$

d. Feed composition (Purina Catfish Food):

$$
\text { Prote in }=36.5 \% \quad \text { Carbohydrates }=42 \%
$$
Fats $=4 \% \quad$ Fiber $-3 \%$

Total nitrogen $=5.8 \% \quad$ Phosphorus $=1 \%$

e. Terramyc in $=0.0055 \%$ fish we ight $/$ day

e. Environmental Requirements:

a. Water temperature comfort zonc $-15^{\circ} \mathrm{C}$ to $35^{\circ} \mathrm{C}$

b. Optimum water temperature $=290 \mathrm{C}$ to $30^{\circ} \mathrm{C}$

c. Water flow rate (raceway culture) $=0.1 .4$ to 0.50 liters $/ \mathrm{min} / \mathrm{kg}$ fish

Water flow rate (pond culture) $=1.1 \times 10^{-4}$ liters $/ \mathrm{min} / \mathrm{kg}$ fish

d. Dissolved oxygen $=6.3$ to $7.3 \mathrm{ppm}$

e. $\mathrm{pH}=5.0$ to 8.5 (optimal $=6.3$ to 7.5 )

f. Stock ing density $=8$ to $160 \mathrm{~kg} / \mathrm{m}^{3}$ (assume

g. Individual raceway volume $=1.2 \mathrm{~m} \times 1.2 \mathrm{~m} \times 15 \mathrm{~m}$ $=21.6 \mathrm{~m}^{3}$ (growing space $=18 \mathrm{~m}^{3}$ )

h. Electrical power required $=112$ to $2500 \mathrm{~kW} / \mathrm{ha}$ 
Table A8

Output Vata Regarding Catfish Production

1. Metabolism and Tissue Production:
a. Stored tissue $=0.0015 \mathrm{~kg} /$ day (average)
b. Moisture fraction of tissue $=0.70$
c. Stored water $=0.00105 \mathrm{~kg} / \mathrm{dav}$
d. Stored solids $=0.00045 \mathrm{~kg} /$ day
e. Eneray content of tissue $=6280 \mathrm{~kJ} / \mathrm{kg}$
f. Weight. dnubling period $=64$ to 1.48 days
g. Total output of fish $=2.2 \times 10^{5}$ to $2.4 \times 10^{6}$ $\mathrm{kg} / \mathrm{ha} / \mathrm{yr}$

2. Solid Wastes:
a. Total solids loss $=1.23 \%$ of body weight $/$ day (assume $0.003 \mathrm{~kg} /$ day)
b. Suspended solids $=1.02 \%$ of body weight $/$ day
c. $B O D$ production $=0.49 \%$ of body weight $/$ day
d. Nitrogen $\left(\mathrm{NH}_{4}-\mathrm{N}=90 \%\right): 0.067 \%$ to body weight/day
Nit.rngen $=4 \%$ to $10 \%$
$\mathrm{P}_{2} \mathrm{O}_{5}=3 \%$ to $9 \%$
C) $N$ ratio $=4$ to $5: 1$
e. Slaughter composition:

3. Water Losscs:
a. 5,000 to $20,000 \mathrm{~m}^{3} / \mathrm{ha} / \mathrm{yr}$ depending on $10 \mathrm{c}$ a 1 weather

4. Heat Losses:

a. Heat loss from tanks (maintaining water temperature at $30^{\circ} \mathrm{C}$ ):

$=1600$ Watts $/ \mathrm{m}^{2}$ at a ir temperature $=-50 \mathrm{C}$

$=1200$ Watts $/ \mathrm{m}^{2}$ at a ir temperature $=00 \mathrm{C}$

$=920$ Watts $/ \mathrm{m}^{2}$ at air temperature $=10^{\circ} \mathrm{C}$

$=540$ Watts $/ \mathrm{m}^{2}$ at air temperature $=20^{\circ} \mathrm{C}$

Note: These heat loss values are on ly approximate.

Heat loss is also a function of wind speed and humidity. 
Table A9

Input Data Regarding Tilapia Production

1. Assumptions:
a. Stagnant pond
b. Growing time to harvest $=300$ days to $0.15 \mathrm{~kg}$; 160 to 180 days to $0.3 \mathrm{~kg}$ (more intensive)
c. Minimum marketable weight $=0.1 \mathrm{~kg}$
d. Fingerling stocking weight $=1$ ton 20 grams

2. Feed:

a. Feed to weight gain ratio $=2$ to $7: 1$

b. Daily consumption (\% of body weight/day) =

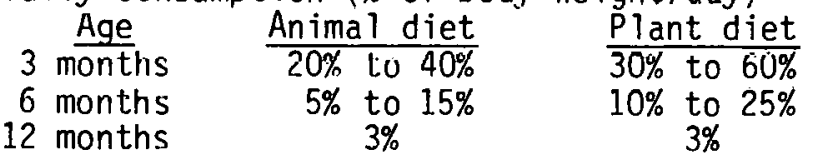

c. Types of feed:

Tilapia are omnivorous, although mainly phytophagous; will eat algae, aquatic plants and most organic wastes.

d. Metabolizable energy content of algae = $10,465 \mathrm{k}, \mathrm{J} / \mathrm{kg}$

e. Solid fraction of alqae $=0.2$

f. Commercial feed $=35 \%$ peanut meal; $35 \%$ soybean meal; 15\% fish meal; 15\% distiller's dry solubles.

2. Environmental Requirements:
a. Water temperature comfort 7 nne $=1.30 \mathrm{C}$ to $380 \mathrm{C}$
(temperatures outside of this range are lethal)
b. Optimum water temperature $=220 \mathrm{C}$ to $350 \mathrm{C}$
c. $\mathrm{O}_{2}$ demand at $250 \mathrm{C}=22$ to $38 \mathrm{mg} 0_{2} / 100$ grams body weight/hour
d. Optimum $\mathrm{pH}=7.5$ to 8.5
e. Stocking density $=10,000$ to $100,000 \mathrm{fish} / \mathrm{ha}$ 
Table A9 (continued)

f. Salinity tolerance ranges from $20 \%$ to $35 \%$

$(1,6)$

g. Electric power required $=$ approximately $3.1 \mathrm{~kW} / \mathrm{ha}$ 
Table A10

Output Data Regarding Tilapia Production

1. Metabolism and Tissue Production:

a. Stored tissue $=1.1 \%$ to $2.0 \%$ of body weight $/$ day (lifetime average)

Percent gain of body weight decreases with age

$10.002 \mathrm{~kg} /$ day average)

b. Moisture fraction of tissue $=0.70$

c. Stored water $=0.0014 \mathrm{~kg} /$ day

d. Stored solids $=0.0006 \mathrm{~kg} /$ day

e. Energy content of tissue $=6280 \mathrm{~kJ} / \mathrm{kg}$

f. Total output of fish varies depending on culture techniques used. Reported extremes range from 200 to $18,000 \mathrm{~kg} / \mathrm{ha} / \mathrm{yr}$. Heavier feeding. oxygenation and use of all-male hybrids result in the highest yields.

2. Solids Wastes:

a. Lack of data; assume values for catfish (Table A8), where unavailable.

b. Fecal solids balance (assuming algae diet): Fecal solids = Feed solids - Stored tissue solids $=$ $0.002-0.0006=0.0014$

c. Slaughter composition: Nitrogen $=4 \%$ to $10 \%$

- $\quad C / N$ ratio $=4$ to $5: 1$

3. Water Losses:

a. 5,000 to $20,000 \mathrm{~m}^{3} / \mathrm{ha} / \mathrm{yr}$ depending on lucal weather

4. Heat Losses:

a. Heat loss from tanks (maintaining water temperature at $30^{\circ}$ ():

$=1600$ Watts $/ \mathrm{m}^{2}$ at a ir temperature $=-50 \mathrm{C}$

$=1200$ Watts $/ \mathrm{m}^{2}$ at a ir temperature $=00 \mathrm{C}$

$=920$ Watts $/ \mathrm{m}^{2}$ at a ir temperature $=10^{\circ} \mathrm{C}$

$=540$ Watts $/ \mathrm{m}^{2}$ at air temperature $=200 \mathrm{C}$

Note: These heat loss values are on ly approximate. Heat loss is also a function of wind speed and humidity. 
Table A].1

Input Vata Regarding Trout Production

1. Assumptions:

a. Raceway culture

b. Marketable size $=0.25$ to 0.30 meters

2. Feed:

a. Feed to weight gain ratio $=1.25$ to $2: 1$, more

$(4,71,72)$ efficient conversion when small (lifetime average $=1.5: 1$ )

b. Daily consumption $=3 \%$ of body weight $/$ day

c. Metabolizable energy in feed $=10,600 \mathrm{~kJ} / \mathrm{kg}$

d. Feed composition (Purina \#20 and \#25 marine ration):

Prote in $=20 \%$

Fats $=10 \%$

Carbohydrates $=49 \%$

Ash $=7 \%$

Fiber $=4 \%$

$\mathrm{H}_{2} \mathrm{O}=1.0 \%$

3. Environmental Requirements:

a. Optimum water temperature $=12^{\circ} \mathrm{C}$ to $16^{\circ} \mathrm{C}$

$(3,4,9)$

b. Water flow rate $=0.35$ liters $/ \mathrm{min} / \mathrm{kg}$ fish

c. $0_{2}$ demand $=49$ to $80 \mathrm{mg} 0_{2} / 100$ grams body weight $/ \mathrm{hr}$. Water should be $95 \%$ saturated with

02 . Minimum concentration $=5 \mathrm{ppm}$.

d. Production density $=2.8 \mathrm{~kg} / \mathrm{liter} / \mathrm{min}$ (on volume has is $=25$ to $50 \mathrm{~kg} / \mathrm{m}^{3}$, but flow rate is the criteria)

e. Stocking density $=0.2$ to $0.4 \mathrm{~kg} / 1 \mathrm{iter} / \mathrm{min}$

f. Electrical power requirement = approximately $1.0 \mathrm{kWh} / \mathrm{kg}$ 
Table A12

Output Data Regarding Trout Production

1. Metabolism and Tissue Production:
a. $\quad$ Stored tissue $=1.9 \%$ to $3.1 \%$ of body weight $/$ day $10.0013 \mathrm{~kg} /$ day lifet ime average)
b. Moisture fraction of tissue $=0.70$
C. Stored water $=0.00091 \mathrm{~kg} /$ day
d. Stored solids $=0.00038 \mathrm{~kg} / \mathrm{day}$
e. Energy content of tissuc $=9200 \mathrm{~kJ} / \mathrm{kg}$
f. Energy required $=15,200 \mathrm{~kJ} / \mathrm{kg}$ of weight gain

2. Solid Wastes:

\begin{tabular}{|c|c|c|}
\hline $\begin{array}{l}\text { Parameter } \\
\text { Settleable Solids } \\
\text { B.O.D. } \\
\text { Nitrates } \\
\text { Ammonia } \\
\text { Phosphates } \\
\mathrm{O}_{2} \text { uptake }\end{array}$ & $\begin{array}{c}\text { Mass Fraction } \\
\text { of Feed } \\
0.30 \\
0.34 \\
0.087 \\
0.032 \\
0.005 \\
0.25\end{array}$ & $\begin{array}{c}\begin{array}{c}\text { Effluent } \\
\text { Concentration }\end{array} \\
4.71 \mathrm{ppm} \\
5.33 \\
1.36 \\
0.5 \\
0.078 \\
3.9\end{array}$ \\
\hline
\end{tabular}

3. Water Losses:
a. 5,000 to $20,000 \mathrm{~m}^{3} / \mathrm{ha} / \mathrm{yr}$ depending upon local weather

4. Heat Losses:

a. Trout require cool water; therefore water heating is seldom required, and heat losses from the water are small. 


\section{APPENDIX B}

This section contains data used for plant growing processes. Also included is a discussion on nutrient uptake by plants.

Nutrient Uptake as Related to Fertilizer Requirements

The wide variation in estimates of crop nutrient requirements indicates both that plant analyses vary with soil analyses and that plant analyses do not provide a clear definition of soil maintenance requirements. The three major nutrients (N, P, and K) react differently. Nitrogen is almost always quite soluble and may change oxidation state depending on the type of soil, soil aeration, and soil bacterial population. If the $\mathrm{N}$ assumes one of its volatile states, such as $\mathrm{N}_{2} \mathrm{O}$ during reduction from $\mathrm{NO}_{3}^{+}\left(\mathrm{N}^{+5}\right)$ to $\mathrm{NH}_{4}^{+}\left(\mathrm{N}^{-3}\right)$, it will be lost. Retention of $\mathrm{NH}_{4}^{+}$ depends on the percentage of clay which holds it by surface adsorption. of the three nutrient requirements, those for nitrogen can be most closely approximated in the short-run by measurement of nitrogen removal in crops. Heavy excess applications lead to increased leaching losses, because of the mobility of $\mathrm{NO}_{3}^{-}$with water movement and low storage capacit.y due to lack of precipitated or bound forms.

Phosphorus; by contrast, is strongly bound and quite $\mathrm{pH}$ sensitive. An excess of calcium and iron brings about the immobilization of large amounts of $P$ and renders the element unavailable to the plants. It can be kept available by $\mathrm{pH}$ adjustment. It should be noted that $\mathrm{P}$ requirements can be substantially lower or higher than removal rates determined by plant analysis even over long time periods. Phosphorus is immobilized in the top $20 \mathrm{~cm}$ of the soil, and as such, its concentration is not 
diminished by water percolation. Reserves of $P$ in soil may be so large that even at soil pH levels of 6.5 to 7.0 and with less of the element added each year than is removed by the crop, yields may not be adversely affected. However, eventually a shortage would occur, and therefore sound practice dictates the maintenance of a reserve of the element in the soil.

As with phosphorus, potassium also is unpredictable on the bas is of uptake measurements. It differs in that its compounds generally are very solublc, and hencc, it is mobilc. In terms of adsorption in elay soils, it resemb les the $\mathrm{NH}_{4}^{+}$ion.

In the present report, adequate soil conditioning is assumed as are the existence of correct background nutrient levels and $\mathrm{pH}$ adjustment for nutrient availability (i.e. steady-state conditions, and therefore no transients). In the face of advice to the contrary in the soil and fertilizer literature, nutrient uptake is used herein as the prime indicator of soil needs. Modern soil management techniques justify this approach and would be applied in any high-output, optimized system such as are considered in this report. An additional assumption of a 20 percent $\mathbb{N}$ loss between application of the element to the soil and the harvesting of the crop is made to account for $\mathrm{N}$-loss instead of attempting to deal with it as a vạriagh le,

In the case of legumes (e.g., alfalfa, clover), nitrogen requirements are drastically reduced as a result of $\mathrm{N}$-fixation through a plantsoil bacteria symbios is.

The value for soil nutrient removal as used in the analyses in the present report are those reported for grain and whole plant analyses. They do not reflect the nitrogen lost through leaching and volatilization 
which, as stated in the preceding paragraphs, can vary considerably. For example, the application of $\mathrm{NO}_{3}-\mathrm{N}$ to a flooded rice paddy under reducing (anaerobic) conditions could be attended by a loss of nitrogen in the form of $\mathrm{N}_{2} \mathrm{O}$ that would be several times greater than the total uptake of nitrogen by even the most active rice hubrids. Un the other hand, under other conditions, the loss could be negligible. It was felt that the purposes of this report could be satisfactorily served by assuming a 20 percent loss of $n$ itrogen. The decision was based upon the facts that manures and digester supernatants characteristically have an appreciable concentration of reduced $\mathrm{N}_{(} \mathrm{NH}_{3}$ or $\left.\mathrm{NH}_{4}^{+}\right)$and the yields indicated in the input-output (mass balance) diagrams represent only moderate levels, and thus imply no overdosing with fertilizer. Furthermore, a detailed investigation of the variation in nitrogen loss with change in field and climatic conditions would be beyond the scope of the present project.

Also contained in this section are the input and output data used in the plant production un it process models. 
Table B1

Data Used in the Mass Balance for a Tomato

Greenhouse Unit Process

Average Fruit Yield: 343 tonnes $/ \mathrm{ha}^{\mathrm{y}} \mathrm{yr}^{\mathrm{a}}$

Average Vine Yield: 20.4 tonnes/ha/yra

NPK Content of Plants: Nitrogen: Fruit -0.971 tonnes/ha/yrb

Vincs $=0.453$ tonnes/ha/yrb

Phosphorus: Fruit -0.137 tonnes/ha/yrc

Vines - 0.062 tonnes $/ \mathrm{ha} / \mathrm{yr}^{\mathrm{c}}$

Potassium: Fruit - 1.715 tonnes/ha/yrd

Vines - 0.567 tonnes/ha/yrd

a Average of yields reported in the literature

$\dot{b} N=0.28 \%$ of fruit weight

$=2.22 \%$ of vine weight

c $P=0.04 \%$ of fruit weight

$=0.31 \%$ of vine weight

$d k=0.50 \%$ of fruit weight

$=2.78 \%$ of vine weight 


$$
\text { Table B2 }
$$

Collection of Tomato Yields Reported in the Literature

Locale

Southwest U.S.A.

Puerto Penasco

Puerto Penasco

Sherco, Minnesota

San Jose, California

TVA Muscle Shoals

Corvallis

Average

Vines (avg. dry weight-tonnes/ha) a,b

\section{Yield \\ (tonnes fruit/ha/yr)}

325

313

257

374

425

336

368

343

\section{$\underline{\text { Reference }}$}

20.4

\footnotetext{
a based on dry wt. vines to be $1 / 16.8$ of yield of truit (79)

b Vines as grown are $87 \%$ mo isture (80)
} 
Estimated Heating Requirements for Greenhouse Uperation

(Inside Temperature $=190 \mathrm{C}$ )

\begin{tabular}{|c|c|c|c|c|}
\hline Location & $\begin{array}{c}\text { Uegree-C } \\
\text { Days } \\
\end{array}$ & $\begin{array}{c}\text { Design Temp } \\
\quad(O C .) \\
\end{array}$ & $\begin{array}{c}\text { Winter Design } \\
\text { Heat Loss } \\
\text { (MW/ha) } \\
\end{array}$ & $\begin{array}{l}\text { Annual } \\
\text { Heat Loss } \\
\text { (GW./ha) } \\
\end{array}$ \\
\hline Birmingham, AL & 1,417 & -6 & 2.8 & 8,340 \\
\hline Anchorage, AK & 6,035 & -29 & 4.4 & 35,510 \\
\hline Tucson, $A Z$ & 1,000 & 0 & 2.5 & 5,880 \\
\hline Little Rock, $M \bar{R}$ & 1,788 & -5 & 2.8 & 10,520 \\
\hline Los Angeles, CA & 749 & 3 & 2.2 & 4,410 \\
\hline San Francisco, CA & 1,675 & 3 & $2: 3$ & 9,870 \\
\hline Jacksonville, FL & 688 & 0 & 2.5 & 4,050 \\
\hline Atlanta, GA & 1,648 & -5 & 2.8 & 9,680 \\
\hline Chicago, IL & 3,268 & -18 & 3.6 & 19,220 \\
\hline South Bend, IN & 3,577 & -18 & 3.6 & 21,040 \\
\hline Dubuque, IA & 4,098 & -22 & 3.9 & $24.1,10$ \\
\hline Lou isville, KY & 2,589 & -11 & 3.7 & 10,020 \\
\hline Fortlánd, ME & 4,173 & -18 & 3.6 & 24,550 \\
\hline Detroit, MI & 3,462 & -1.3 & 3.4 & 20,370 \\
\hline Duluth, MN & 5,556 & -26 & 4.2 & 32,680 \\
\hline Kansas City, MO & 2,617 & -13 & 3.4 & 15,400 \\
\hline Buffalo, NY & 3,923 & 14 & 3.4 & 23,080 \\
\hline Charlotte, NC & 1,773 & -6 & 2.8 & 10,430 \\
\hline Cleveland, $\mathrm{OH}$ & 3,528 & -11 & 3.2 & 20,760 \\
\hline Knoxville, TN & 1,941 & -8 & 3.0 & 11,420 \\
\hline Laredo, TX & 443 & 2 & 2.3 & 2,610 \\
\hline
\end{tabular}

Reference (12) 
Table B4

NPK Content of Grains and Principal Forage Crops (percent)

Crop

Alfalfa

Clover

Corn

0ats

Rice.

Sorghum

Timothy

Wheat

References $(8,81)$
N

$2.3-3.1$

$2.0-2.8$

2.8

$1.5-1.6$

$2.2-2.4$

3.4

$1.2-1.9$

2.9

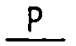

0.2-0.4

$0.2-0.4$

$0.3-0.5$

$0.3-0.4$

$0.4-2.0$

$0.2-0.6$

$0.2-0.3$

0.4
1.8

K

$1.8-2.1$

1.7-2.5

$0.9-1.8$

1.8

$1.8-1.9$

2.7

0.9-1.6 
Table B5

Growth and NPK Uptake of Sorghum, Corn, and Hay

\begin{tabular}{|c|c|c|c|c|}
\hline \multirow[t]{2}{*}{ Item } & \multirow[t]{2}{*}{$\begin{array}{c}\text { Tota } 1 \\
\text { (kg/ha-day) }\end{array}$} & \multicolumn{3}{|c|}{$\begin{array}{c}\text { Element } \\
(\mathrm{kg} / \mathrm{ha}-\mathrm{day})\end{array}$} \\
\hline & & $N$ & $P$ & $k^{\prime}$ \\
\hline SORGHUM & & & - & \\
\hline grain & 24.7 & 0.370 & 0.068 & 0.088 \\
\hline stover & -- & 0.361 & 0.049 & 0.493 \\
\hline uptake & -- & 0.732 & 0.115 & 0.581 \\
\hline
\end{tabular}

CORN

$\begin{array}{lllll}\text { grain } & 23.3 & 0.370 & 0.063 & 0.088 \\ \text { stover } & 19.5 & 0.222 & 0.038 & 0.348 \\ \text { uptake } & & 0.592 & 0.101 & 0.436\end{array}$

MIXED - CLOVER-ALFALFA

hay

37.0

1.000

0.096

0.666 
Table B6

Water Hyacinth Chemical Content

(whole plant percent dry weight)

\author{
Prote in \\ Fat \\ Carbohydrate \\ Fiber \\ Ash \\ Total Kje ldah1 Nitrogen \\ Phosphorous \\ Potassium \\ Metabolic Energy Content
}

$9.7-23.4$

$1.6-2.2$

$36.9-51.6$

$17.1-19.5$

$11.1-20.4$

$1.6-3.7$

$0.31-0.89$

$1.6-3.4$

$2.7-3.1$

References $(82,83)$ 
THIS PAGE

\section{WAS INTENTIONALLY \\ LEFT BLANK}


113

APPENDIX C

This section contains data used for water treatment processes.

Values have been averaged from a variety of sources. 
Table C1

Composition of Raw (Primary) and Treated (Secondary) Sewage (mg/liter)

Item

A. Raw Sewage

Total Solids

Uissolved Solids

Suspended Solids

Volatile Solids

Nitrogen

Phosphorous

Potassium

B. Secondary Sewage

Dissolved Solids

Nitrngen

Phosphorus

Potassium
Average

$700-1.570$

$500 a-1030$

$200^{b}-540$

$350-780$

$40 C-41$

$5.6-10$

$24-25$

920

21

13

20
Fraction of Total Solids Variation

1

$0.6 y$

$0.2-0.94$

0.32

$0.16-0.8$

0.50

$0.2-0.5$

0.042

$0.026-0.057$

0.0089

$0.004-0.014$

0.0033

$0.015-0.035$

a Vol. solids, $200 \mathrm{mg} / 1$ iter

h Vol. solids, 150 iily/liler

c $\mathrm{NH}_{3}, 25 \mathrm{mg} / 1$ iter 
Table C2

Composition of Raw (Primary), Activated, and Digested Sludges
(percent of total solids)

Item $\quad$ Average $\quad$ Range $\quad \begin{aligned} & \text { Fraction of } \\ & \text { Total Solids }\end{aligned}$

A. Raw

Total Solids

$5.7 a$

$2-10$

1

Volatile Solids

70

$60-80$

0.7

Nitrogen

3.6

$1.5-5.0$

0.036

Phosphorus

0.84

$0.35-1.22$

0.0084

Potassium

0.35

$0-0.83$

0.0035

B. Activated

Total Solids

$1.2^{a}$

$0.5-2.0$

1

Volatile Solids

70

$65-85$

0.7

Nitrogen

5.8

$2.3-8.0$

0.058

Phosphorus

1.9

$1.1-4.8$

0.019

Potassium

0.35

$0-1.0$

0.0035

C. Digested

Total Solids

$6.5^{a}$

$2-12$

1

Dissolved Solids

7

--

0.07

Volatile Solids

48

$30-62$

0.48

Nitrogenb

4.0

$1.6-6.0$

0.04

Phosphorus

1.6

$0.8-3.9$

0.016

Potassium

0.6

$0 \cdot-2.5$

0.006

a Solids content of the sludge "as is"

b The nitrogen is split almost evenly between the liquid and the dissolved solids. 
Tab le C3

Primary and Secondary Sewage Treatment Removal Efficiencies

$\begin{array}{ccc}\text { Primary } & \text { Secondary } & \text { Primary }+ \text { Secondarya } \\ \text { Avg. Range } & \text { Avg. Range } & \text { Avq. Range }\end{array}$

$\begin{array}{lrccccc}\text { B.0.D. } & 32 & 22-49 & 87 & 81-96 & 91 & 88-9 \\ \text { Nitrogen } & 9 & 9 & -- & -- & 40^{\mathrm{b}} & 40-60 \\ \text { Phosphorus } & 11 & 10-12 & -- & -- & 32 & 32-33 \\ \text { Total Solids } & 20 & 20 & -- & -- & -- & -- \\ \text { Susp. Solids } & 66 & 60-68 & 79 & 70-96 & 93 & 90-99 \\ \text { Vol. Solids } & 38 & 38 & -- & -- & -- & --\end{array}$

acumulative

buncerta in 
Table C4

Data Regarding Algae Production

(Ranges for Chlorella, Scenedesmus, Spirulina)

Dried Algae

T.S. $\simeq 90$ to 96 percent

Bound Water $\approx 4$ to 10 percent

Ash $\simeq 6$ to 10 percent

Algal cell is about 80 percent $\mathrm{H}_{2} \mathrm{O}$

Average Composition (dry weight)

$$
\begin{aligned}
& N \simeq 6 \text { to } 8 \text { percent } \\
& H \simeq 1.2 \text { to } 2.6 \text { percent } \\
& K \approx 0.4 \text { to } 1.6 \text { percent }
\end{aligned}
$$

$\underline{\text { Yields }}$

45 to $240 \mathrm{~kg} / \mathrm{ha} / \mathrm{day}$

Concentrations

$$
10^{5} \text { to } 10^{\prime} \text { cells/ml }
$$

Yond Vepth

$$
\begin{aligned}
& \text { Uptimum } \simeq 11 \mathrm{~cm} \\
& \text { Practical } \simeq 20 \text { to } 35 \mathrm{~cm}
\end{aligned}
$$

Evaporation from Pond

0.51 to $5.1 \mathrm{~cm} /$ week

BOD Reduction

About 80 to .90 percent

References $(17,33,84,85)$ 


\section{THIS PAGE}

\section{WAS INTENTIONALLY \\ LEFT BLANK}


APPENDIX D

This section contains details concerning the mass balance analyses of the integrated complexes studied. Additional detail and calculations are given for the first case to better acquaint the reader with the integration procedure. 


\section{Development of the Chicken-Digester-Algae-Tilapia Complex}

Relying upon the unit process models developed, the block diagram shown in Figure DI was drawn. The network analyses used in arriving at transfer functions for the model are as follows:

$$
\begin{aligned}
& x_{1}=u+x_{8}+x_{9} \\
& x_{2}=k_{3} x_{1} \\
& x_{3}=x_{5}+x_{6}+x_{7}+k_{7} x_{2}=\left(k_{2}+k_{4}\right) x_{1}+k_{14} x_{4} \\
& +k_{7} k_{3} x_{1}=\left(k_{2}+k_{4}+k_{7} k_{3}\right) x_{1}+k_{14} x_{4} \\
& x_{4}=k_{10} x_{3} \\
& x_{5}=k_{2} x_{1} \\
& x_{6}=k_{4} x_{1} \\
& x_{7}=k_{14} x_{4} \\
& x_{8}=k_{9} x_{3} \\
& x_{9}=k_{11} x_{3} \\
& y=k_{13} x_{4} \\
& x_{3}=\left(k_{2}+k_{4}+k_{7} k_{3}\right)\left(u+\left(k_{9}+k_{11}\right) x_{3}\right)+k_{1.4} k_{10} x_{3} \\
& x_{3}=\frac{k_{2}+k_{4}+k_{7} k_{3}}{1-k_{14} k_{10}-\left(k_{2}+k_{4}+k_{7} k_{3}\right)\left(k_{9}+k_{11}\right)} u \\
& y=k_{13^{x_{4}}}=k_{13^{k}} k_{10} x_{3} \\
& y=\frac{\left(k_{13} k_{10}\right)\left(k_{2}+k_{4}+k_{7} k_{3}\right)}{1-k_{14} k_{10}-\left(k_{0}+k_{4}+k_{7} k_{3}\right)\left(k_{8}+k_{11}\right)} u=k u \\
& x_{2}=k_{3} x_{1}=k_{3}\left(u+x_{8}+x_{9}\right)=k_{3}\left(u+\left(k_{y}+k_{11}\right) x_{3}\right) \\
& x_{2}=k_{3}\left(1+\left(k_{9}+k_{11}\right) \frac{\left(k_{2}+k_{4}+k_{7} k_{3}\right)}{1-k_{14} k_{10}-\left(k_{2}+k_{4}+k_{7} k_{3}\right)\left(k_{9}+k_{11}\right)}\right) u=L u \\
& x_{1}=u+\left(k_{11}+k_{9}\right) \frac{\left(k_{2}+k_{4}+k_{7} k_{3}\right) u}{1-k_{34} k_{10}-\left(k_{2}+k_{1}+k_{7} k_{3}\right)\left(k_{9}+k_{11}\right)} \\
& x_{1}=\left(1+\left(k_{11}+k_{9}\right) \frac{\left(k_{2}+k_{4}+k_{7} k_{3}\right)}{1-k_{14} k_{10}-\left(k_{2}+k_{4}+k_{7} k_{3}\right)\left(k_{9}+k_{11}\right)} u=M u\right.
\end{aligned}
$$

The constants assigned to the various elements in the model are numerical $\forall a l u e s$ taken either individually from the literature or averaged. They are listed in Table Dl. Calrulations based on the data and on the analysis are given in Table D2. 


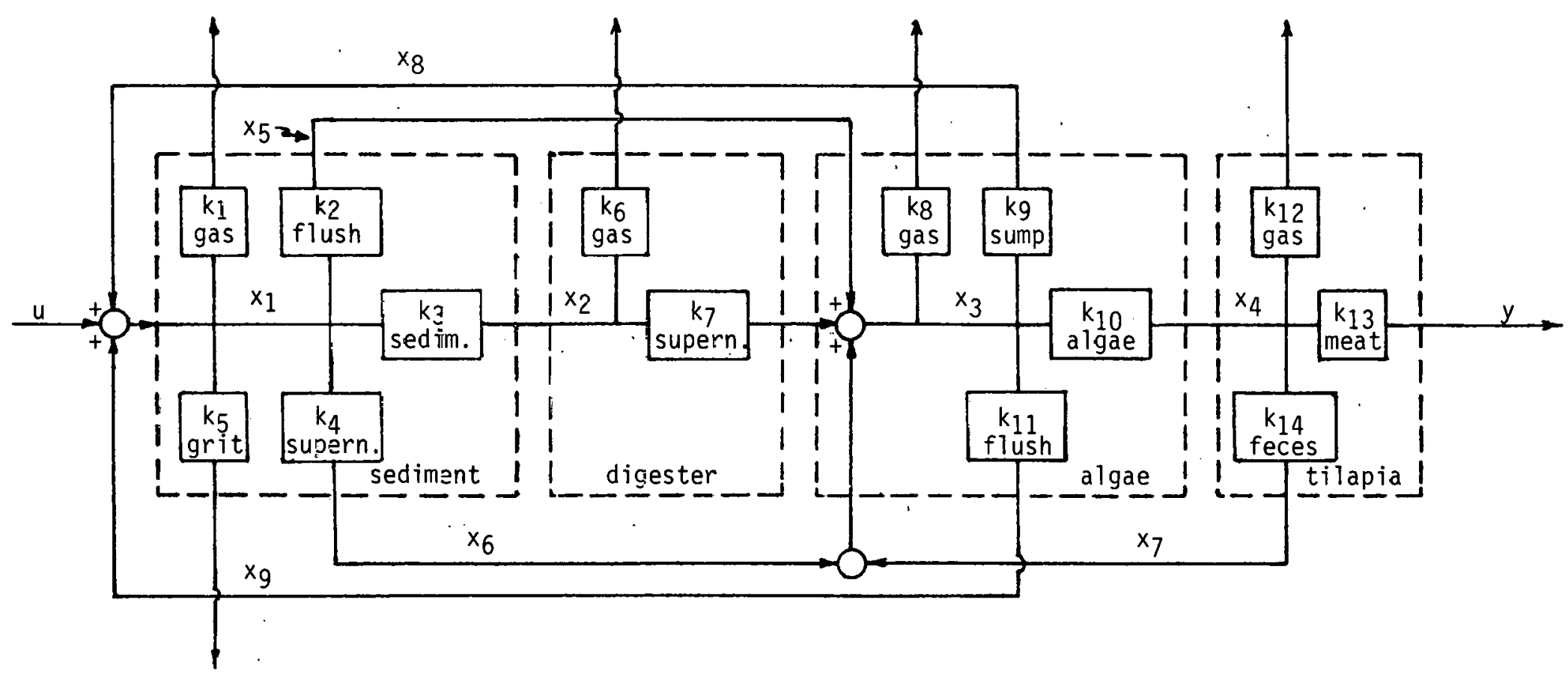

Figure D1. Block diagram model of a Chicken-nigester-Algae-Tilapia Complex. 
Table D1

Transfer Functions for the Chicken-Digester-Algae-Tilapia Complex

\begin{tabular}{lllll}
\multicolumn{1}{c}{ Item } & $k$ & $\begin{array}{l}\text { Total } \\
\text { Solids }\end{array}$ & $\begin{array}{c}\text { Volatile } \\
\text { Solids }\end{array}$ & Nitrogen \\
\hline Gas & $k_{1}$ & 0.127 & 0.172 & 0.039 \\
H lushwater & $k_{2}$ & 0.333 & 0.300 & 0.536 \\
Settled solids & $k_{3}$ & 0.181 & 0.206 & 0.098 \\
Supernatant & $k_{4}$ & 0.311 & 0.323 & 0.327 \\
Grit & $k_{5}$ & 0.047 & 0.0 & 0.0 \\
Gas & $k_{6}$ & 0.554 & 0.680 & 0.0 \\
Supernatant & $k_{7}$ & 0.446 & 0.320 & 1.0 \\
Gas & $k_{8}$ & 0.281 & 0.298 & 0.167 \\
Sump & $k_{9}$ & 0.169 & 0.163 & 0.243 \\
Algap & $k_{10}$ & 0.100 & 0.111 & 0.013 \\
Flushwater. & $k_{11}$ & 0.451 & 0.426 & 0.557 \\
Gas & $k_{12}$ & 0.595 & $0.595 \mathrm{a}$ & $0.600^{\mathrm{a}}$ \\
Meat solids & $k_{13}$ & 0.155 & $0.155^{\mathrm{a}}$ & $0.212^{\mathrm{a}}$ \\
Manure & $k_{14}$ & 0.250 & $0.250^{\mathrm{a}}$ & $0.188^{\mathrm{a}}$ \\
\hline & & & & \\
\hline
\end{tabular}

aEstimated value

bTo arrive at. a number for wet fish mass, multiply by 3.23 
Table D2

Throughput Constants for the Chicken-DigesterAlgae-Tilapia Comp lex

Equation

Item
Total

Solids
Volatile Solids
Nitrogen
0.689
0.961

$\left(k_{2}+k_{4}+k_{7} k_{3}\right)$

0.725

0.0278

0.0062

$\left(k_{14} k_{10}\right)$

0.025

0.589

0.800

$\left(k_{9}+k_{11}\right)$

$=0.620$

$1.216 \mathrm{u}$

$4.27 u$

$x_{3}$

$=$

$=$

$x_{1}$

$x_{2}=k_{3} x_{1}$

$1.38 u$

$1.716 u$

$4.42 u$

$=$

$1.85 u$

$0.354 u$

$0.433 u$

$x_{4}=k_{10} x_{3}$

$=$

$0.335 u$

$0.135 u$

$0.141 u$

$x_{5}=k_{2} x_{1}$

$=$

$0.138 u$

$0.515 \mathrm{u}$

$2.37 u$

$x_{6}=k_{4} x_{1}$

$0.616 u$

$0.554 \mathrm{u}$

$1.45 u$

$x_{7}=k_{14} x_{4}$

$0.575 u$

$0.035 u$

$0.034 u$

$0.027 \mathrm{u}$

$x_{8}=k_{9} x_{3}$

$0.233 u$

$0.198 u$

$1.04 u$

$x_{9}=k_{11} x_{3}$

$0.622 u$

$0.518 u$

$2.38 u$ 
The transfer functions can be used to determine the amounts of nitrogen and phosphate that can be recovered as we 11 as fish and methane production:

1. Yield of fish (wet weight) as a function of input manure: In making this calculation it should be noted that the transfer function is not suited to the determination of fish yield,. since the function merely states the fraction of the input total solids that is cunverted to algal solids. The yield of fish can be ascertained through a determination of $x_{1 N}$ which leads to the determination of algal mass, and from the latter to a determination of yield of fish. The calculations are as follows:

$x_{4 N}=Y_{N} / k_{13 N}=\frac{.0298}{.212}=.1406 \frac{g N \text { in alqae }}{g N \text { in manure }}$.

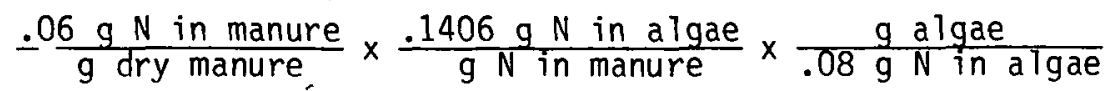
$=\frac{.1054 \mathrm{~g} \text { algae }}{\mathrm{g} \text { dry manure }}$

$\frac{.1054 \mathrm{~g} \text { algae }}{\mathrm{g} \text { manure }} \times \frac{1 \mathrm{~g} \text { wet } \mathrm{fish}}{2 \mathrm{~g} \text { algae }}=.0527 \frac{\mathrm{g} \text { wet } \mathrm{fish}}{\mathrm{g} \text { dry manure }}$

2. Nitrogen recovery: The extent of nitrogen recovery is ralculated as follows:

$Y_{N}=\frac{(.212)(.033)}{1-(0.188)(.033)-(.536+.327+.098)} \frac{(.327+.098)(.243+.557)}{36+.37}$

$\mathrm{Y}_{\mathrm{N}}=.0298 \frac{\mathrm{g} \mathrm{N} \text { in fish }}{\mathrm{gN} \text { in manure }}$

$\frac{\mathrm{g} \text { dry fish solids }}{.109 \mathrm{~g} \mathrm{~N} \text { in fish }} \times \frac{.0298}{9 \mathrm{~N}} \frac{\mathrm{g} \mathrm{N} \text { in fish }}{\text { in manure }} \times \frac{.06 \mathrm{~g} \mathrm{~N} \text { in manure }}{\mathrm{g} \text { manure }}$

$=.0164 \frac{g \text { dry rish sulids }}{\text { g manure solids }}$

3. Methane Production: The calculation for arriving at methane production on the basis of total solids is as follows: 


$$
\begin{aligned}
& x_{2}=k_{3}\left(1+\frac{\left(k_{9}+k_{11}\right)\left(k_{2}+k_{4}+k_{7} k_{3}\right)}{1-k_{14} k_{10}-\left(k_{2}+k_{4}+k_{7} k_{3}\right)\left(k_{9}+k_{11}\right)}\right) \\
& =(.181)\left(1+\frac{(.62)(.725)}{1-(.025)-(.62)(.725)}\right)=.336 \frac{\text { g biogas }}{\text { ganure solids }} \\
& \text { Sixty percent of } \mathrm{CH}_{4} \text { (by volume) gives }
\end{aligned}
$$

$\frac{.60 \times 16}{.6 \times 16+.4 \times 44}=.353$ or $35.3 \%$ of $\mathrm{CH}_{4}$ by weight

the yield is $(.353)(.336)=.119 \frac{\mathrm{g} \mathrm{CH}_{4}}{\mathrm{~g} \text { dry manure solids }}$

4. Phosphate Recovery: In calculating the ratio of phosphate recovery to manure input, it is assumed that one percent of the wet weight of fish is phosphorus. Then, allowing for algal uptake, 98.3 percent of the phosphate in the manure would be precipitated in the algae pond during times of high $\mathrm{pH}$ levels. The potential precipitation of phosphorus would then be:

$$
\begin{aligned}
& \frac{0.03 \mathrm{~g} P}{g \text { dry manure }} \times \frac{0.98 \mathrm{~g} \mathrm{P} \text { precip. }}{\mathrm{g} P \text { input }} \times \frac{310 \mathrm{~g} \mathrm{CA}_{3}\left(\mathrm{PO}_{4}\right)_{2}}{62 \mathrm{~g} \mathrm{P}} \\
& =0.148 \frac{\mathrm{g} \mathrm{Ca}_{3}\left(\mathrm{PO}_{4}\right)_{2}}{\mathrm{~g} \text { dry manure }}
\end{aligned}
$$

The transfer functions are applicable throughout for nitrogen. However, with respect to total mass, the coefficients for total solids can not be used to determine algal mass $\left(x_{4}\right)$ and fish mass $(y)$. The reason is that $\mathrm{CO}_{2}$ exchange at the pond surface is not taken into account. Total solids cannot be taken as a feedback, because no data are given for gas exchange $\left(\mathrm{O}_{2}\right.$ and $\left.\mathrm{CO}_{2}\right)$ between the atmosphere and the pond surface. Yet, this exchange could strongly affect the amount of algae produced. The effects on the transfer function values of various hypothetical feedback loops are more easily expressed by way of the nitrogen balances. Thus, algal mass production can be estimated through the use of 
nitrogen $x_{4 N}$, the usual nitrogen content of algae $(0.08)$, and a fish mass based on a 2:1 feed conversion. 
Development of the Greenhouse-Cattle-Digester-Open Field Complex

A proposed block diagram model for a complex in which tomatoes would constitute the greenhouse crop; and corn, the open field crop is shown in Figure 02. The network analysis used in arriving at transfer functions for the model is as follows:

$$
\begin{aligned}
& x_{1}=k_{2} u \\
& x_{2}=x_{1}+x_{6} \\
& x_{3}=k_{4} x_{2} \\
& x_{4}=x_{3}+x_{7}+x_{8} \\
& x_{5}=k_{6} x_{4}=k_{6}\left(x_{3}+x_{7}+x_{8}\right)=k_{6}\left(k_{4} x_{2}+k_{10} x_{5}+k_{1} u\right) \\
& x_{5}=\frac{k_{6}\left(k_{4} k_{2}+k_{1}\right)}{1-\left(k_{6} k_{4} k_{8}+k_{6} k_{10}\right)} u \\
& x_{6}=k_{8} x_{5} \\
& x_{7}=k_{10} x_{5} \\
& x_{8}=k_{1} u \\
& y=k_{9} x_{5}
\end{aligned}
$$

The equations given above can be solved by multiplying the inputs to the unit processes by the corresponding transfer functions given in Table D3: 


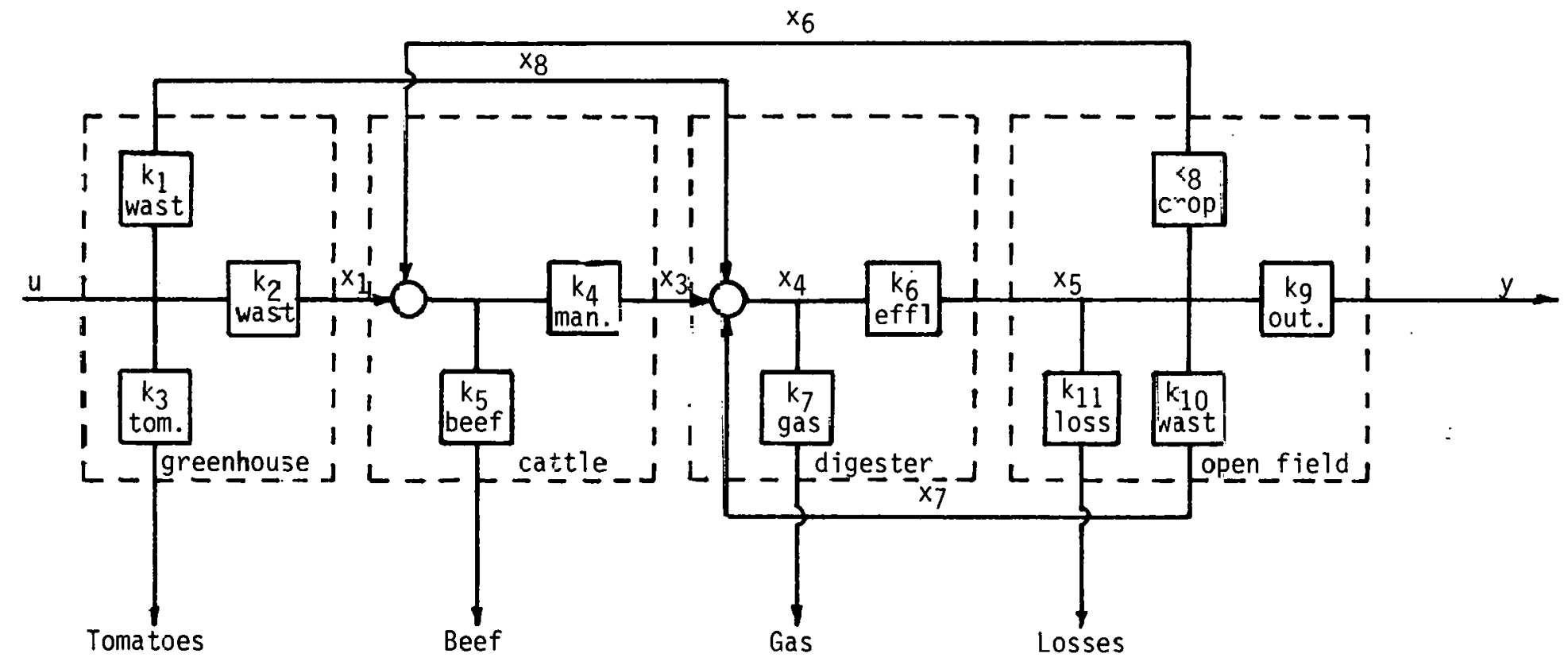

Figure D2. Block diagram model of a Greenhouse-Cattle-pigester-0pen Field Complex. 
Table D3

Transfer Functions for the GreenhouseCattle-Digester-Open Field Complex

$\begin{array}{lllll} & & N & & \text { N } \\ \text { Greenhouse vine wastes } & & & & \\ \text { Cannery wastes } & k_{1} & 0.31 & 0.30 & 0.25 \\ \text { Tomatoes } & k_{2} & 0.01 & 0.01 & 0.01 \\ \text { Manure } & k_{3} & 0.67 & 0.70 & 0.74 \\ \text { Beef } & k_{4} & 0.80 & 0.73 & 0.67 \\ \text { Digester effluent } & k_{5} & 0.20 & 0.27 & 0.33 \\ \text { Digester gas } & k_{6} & 1.00 & 1.00 & 1.00 \\ \text { Open field crops (corn) } & k_{7} & 0.00 & 0.00 & 0.00 \\ \text { Output (corn) } & k_{8} & 0.49 & 0.42 & 0.14 \\ \text { Crop wastes (corn) } & k_{9} & 0.00 & 0.00 & 0.00 \\ \text { Open field losses (corn) } & k_{10} & 0.31 & 0.26 & 0.58 \\ & k_{11} & 0.20 & 0.32 & 0.28\end{array}$


Development of the Chicken-Catt le-Digester-Open Field Complex

A block diagram model of this system is presented in Figure D3. The network analysis used in arriving at transfer functions for the model is as follows.

$$
\begin{aligned}
& x_{1}=x_{17}+x_{26}+x_{31} \\
& x_{2}=k_{1} x_{1} \\
& x_{3}=k_{3} x_{3} \\
& x_{4}=k_{2} x_{1} \\
& x_{5}=x_{4}+x_{16}+x_{22}+x_{27} \\
& x_{6}=k_{0} x_{5} \\
& x_{7}=k_{4} x_{5} \\
& x_{8}=k_{5} x_{5} \\
& x_{9}=x_{8}+x_{19}+x_{29} \\
& x_{10}=k_{7} x_{9} \\
& x_{11}=k_{8} x_{9} \\
& x_{12}=k_{9} x_{9} \\
& x_{13}=k_{10} x_{9} \\
& x_{14}=u_{2}+x_{12} \\
& x_{15}=k_{13} x_{14} \\
& x_{16}=k_{14} x_{14} \\
& x_{17}=k_{12} x_{14} \\
& x_{18}=k_{11} x_{14} \\
& x_{19}=k_{11} x_{14} \\
& x_{20}=u_{3}+x_{11} \\
& x_{21}=k_{16} x_{20} \\
& x_{22}=k_{15} x_{20} \\
& x_{23}=x_{2}+x_{7} \\
& x_{24}=k_{23} x_{23} \\
& x_{25}=k_{22} x_{23} \\
& x_{20}=k_{20} x_{23} \\
& x_{27}=k_{21} x_{23} \\
& x_{28}=u_{1}+x_{13} \\
& x_{29}=k_{17} x_{28} \\
& x_{30}=k_{19} x_{30} \\
& x_{31}=k_{18} x_{30} \\
& x_{3}
\end{aligned}
$$




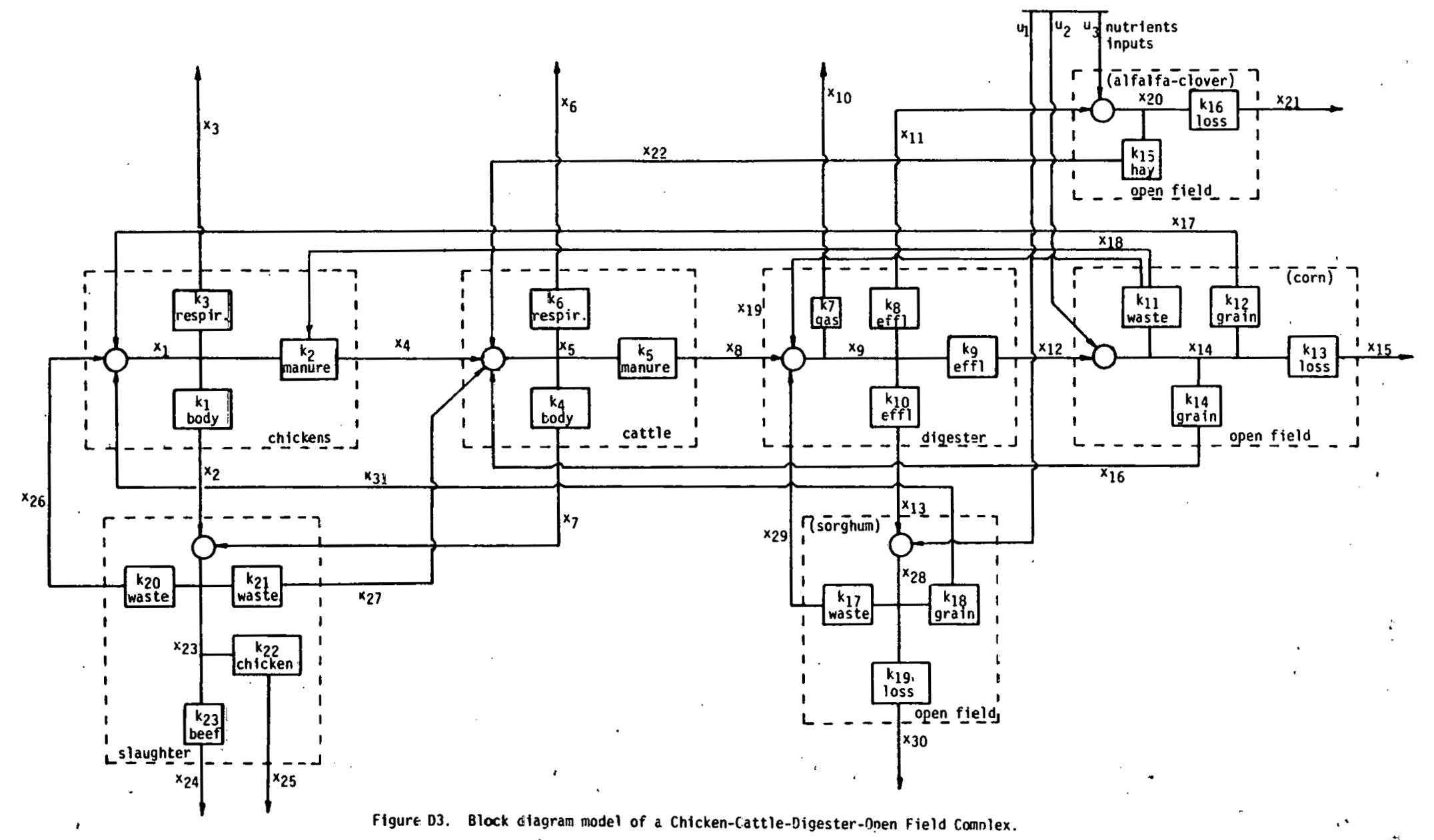


The equations given above can be solved by multiplying the inputs to the unit processes by the corresponding transfer functions given in Table D4. 
Table D4

Transfer Functions for the ChickenCatt le-Digester-Open Field Complex

Chicken body
Chicken manure
Chicken respiration
Cattle body
Cattle manure
Cattle respiration
Digester gas
Digester effluent
Digester effluent
Digester effluent
Corn waste
Corn grain
Corn field loss
Corn grain
Hay
Hay field loss
Sorghum waste
Sorghum grain
Sorghum field loss
Slaughter wastes
Slaughter wastes
Chicken
Beef

\begin{tabular}{|c|c|c|c|}
\hline & $\mathrm{N}$ & $P$ & $K$ \\
\hline$k_{1}$ & 0.60 & 0.38 & -- \\
\hline$k_{2}$ & 0.40 & 0.62 & -- \\
\hline$k_{3}$ & 0.00 & 0.00 & 0.00 \\
\hline$k_{4}$ & 0.18 & 0.27 & -- \\
\hline$k_{5}$ & 0.82 & 0.73 & -- \\
\hline$k_{6}$ & 0.00 & 0.00 & 0.00 \\
\hline$k_{7}$ & 0.00 & 0.00 & 0.00 \\
\hline$k_{8}$ & 0.29 & 0.29 & 0.29 \\
\hline$k_{9}$ & 0.66 & 0.66 & 0.66 \\
\hline$k_{10}$ & 0.053 & 0.053 & 0.053 \\
\hline$k_{11}$ & 0.27 & 0.28 & 0.72 \\
\hline$k_{12}$ & 0.12 & 0.13 & 0.05 \\
\hline$k_{13}$ & 0.30 & 0.24 & 0.10 \\
\hline$k_{14}$ & 0.32 & 0.35 & 0.14 \\
\hline$k_{15}$ & 0.80 & 0.76 & -- \\
\hline$k_{16}$ & 0.20 & 0.24 & -- \\
\hline$k_{17}$ & 0.30 & 0.19 & 0.61 \\
\hline$k_{18}$ & 0.30 & 0.27 & 0.11 \\
\hline$k_{19}$ & 0.40 & 0.54 & 0.28 \\
\hline$k_{20}$ & 0.15 & 0.15 & -- \\
\hline$k_{21}$ & 0.21 & 0.21 & -- \\
\hline$k_{22}$ & 0.29 & 0.24 & -- \\
\hline$k_{23}$ & 0.34 & 0.40 & -- \\
\hline
\end{tabular}


Development of the Sewage-Digester-Hyacinth-Swine Complex

A block diagram model of this system is presented in Figure 04 . The network analysis used in arriving at transfer functions for the model is as follows.

$$
\begin{aligned}
& x_{1}=k_{1} u \\
& x_{2}=k_{2} u \\
& x_{3}=k_{3} u \\
& x_{4}=x_{2}+x_{12}+x_{16}=k_{2} u+k_{10} x_{8}+k_{13} x_{15}
\end{aligned}
$$

Suljstituting and solving:

$$
\begin{aligned}
& x_{4}=\frac{k_{2}+k_{10}\left(k_{1}+k_{11} k_{3}\right)+\frac{k_{13}}{1-k_{16} k_{14}}\left(k_{9}\left(k_{1}+k_{13} k_{3}\right)+k_{12} k_{3}\right)}{1-\left(k_{10} k_{5}+\frac{k_{13}\left(k_{6}+k_{9} k_{5}\right)}{1-k_{16} k_{14}}\right.} u \\
& x_{5}=k_{4} x_{4} \\
& x_{6}=k_{5} x_{4} \\
& x_{7}=k_{6} x_{4} \\
& x_{8}=x_{1}+x_{6}+x_{13} \\
& x_{9}=k_{7} x_{8} \\
& x_{10}=k_{8} x_{8} \\
& x_{11}=k_{9} x_{8} \\
& { }^{x_{12}}=k_{10} x_{8} \\
& x_{13}-k_{11} x_{3} \\
& x_{14}=k_{12} x_{3} \\
& x_{15}=x_{7}+x_{11}+x_{14}+x_{18}=k_{6} x_{4}+k_{9} x_{8}+k_{12} k_{3} 3^{u+k_{16}} k_{14} x_{15} \\
& x_{15}=\frac{\left(k_{6}+k_{9} k_{5}\right) x_{4}+\left(k_{9} k_{1}+k_{9} k_{11} k_{3}+k_{12} k_{3}\right) u}{1-k_{16} k_{14}} \\
& \mathrm{x}_{16}=\mathrm{k}_{1.3} \mathrm{x}_{15} \\
& x_{17}=k_{14} x_{15} \\
& x_{18}=k_{16} x_{17} \\
& y=k_{15^{x}}{ }^{\mathrm{x}} \\
& y=k_{14} k_{15} x_{15}=\left(k_{14} k_{15}\right) \frac{\left(k_{6}+k_{9} k_{5}\right) x_{4}+\left(k_{9} k_{1}+k_{9} k_{11} k_{3}+k_{12} k_{3}\right)}{1-k_{16} k_{14}} u
\end{aligned}
$$




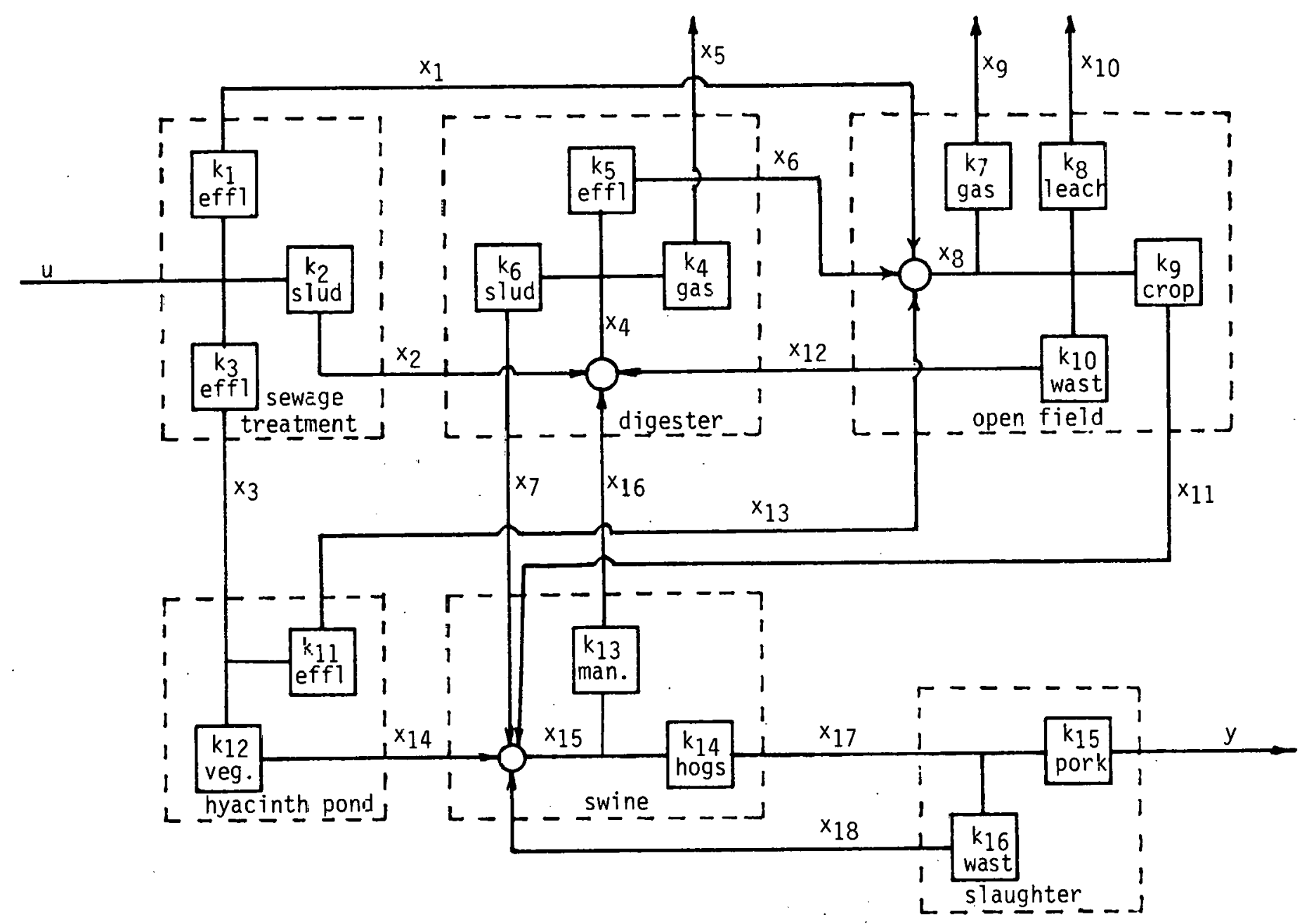

Figure D4. Block diagram model of a Sewage-Digester-Hyacinth-Swine-Open Field Complex. 
The equations given above can be solved by multiplying the inputs to the unit processes by the corresponding transfer functions given in Table D5. 
Table 05

Transfer Functions for the Sewage-

Digester-Hyac inth-Swine Complex

Sewage effluent

Sewage sludge

Sewage effluent

Digester gas

Digester effluent

Digester sludge

Field losses (gas)

Field losses (solids)

Grain

Crop wastes

Pond effluent

Hyacinths

Swine manure

Swine body

Pork

Slaughter wastes

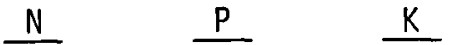

$k_{1}$

0.45

0.49

0.63

$k_{2}$

0.37

0.32

0.12

$k_{3}$

0.18

0.19

0.25

$k_{4}$

0.00

0.00

0.00

$k_{5}$

0.88

0.77

0.97

$k_{6}$

0.12

0.23

0.03

$k_{7}$

0.20

0.00

0.00

$k_{8}$

0.20

0.56

0.49

$k_{9}$

0.34

0.26

0.09

$k_{10}$

0.26

0.18

0.42

$k_{11}$

$k_{12}$

0.12

0.22

0.30

0.88

0.78

0.70

0.54

0.72

0.80

$k_{14}$

0.46

0.28

0.20

$k_{15}$

0.69

0.69

0.69

$k_{16}$

0.31 .

0.31

0.31 


\section{THIS PAGE}

\section{WAS INTENTIONALLY \\ LEFT BLANK}


APPENDIX E 


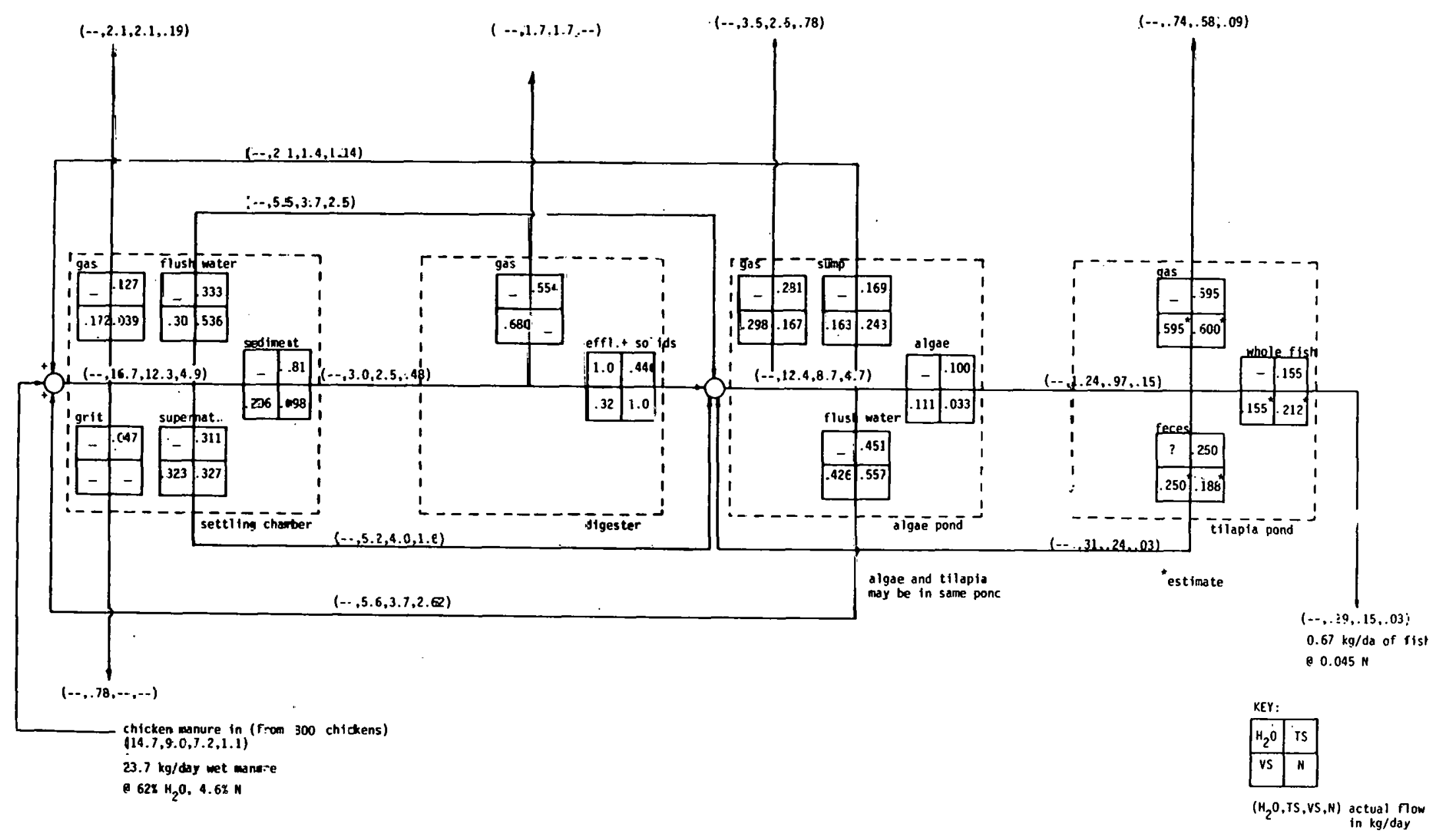

Figure E1. Integration of mass balances in the Chicken Manure-Digester-Algae-Tilapia Complex. 


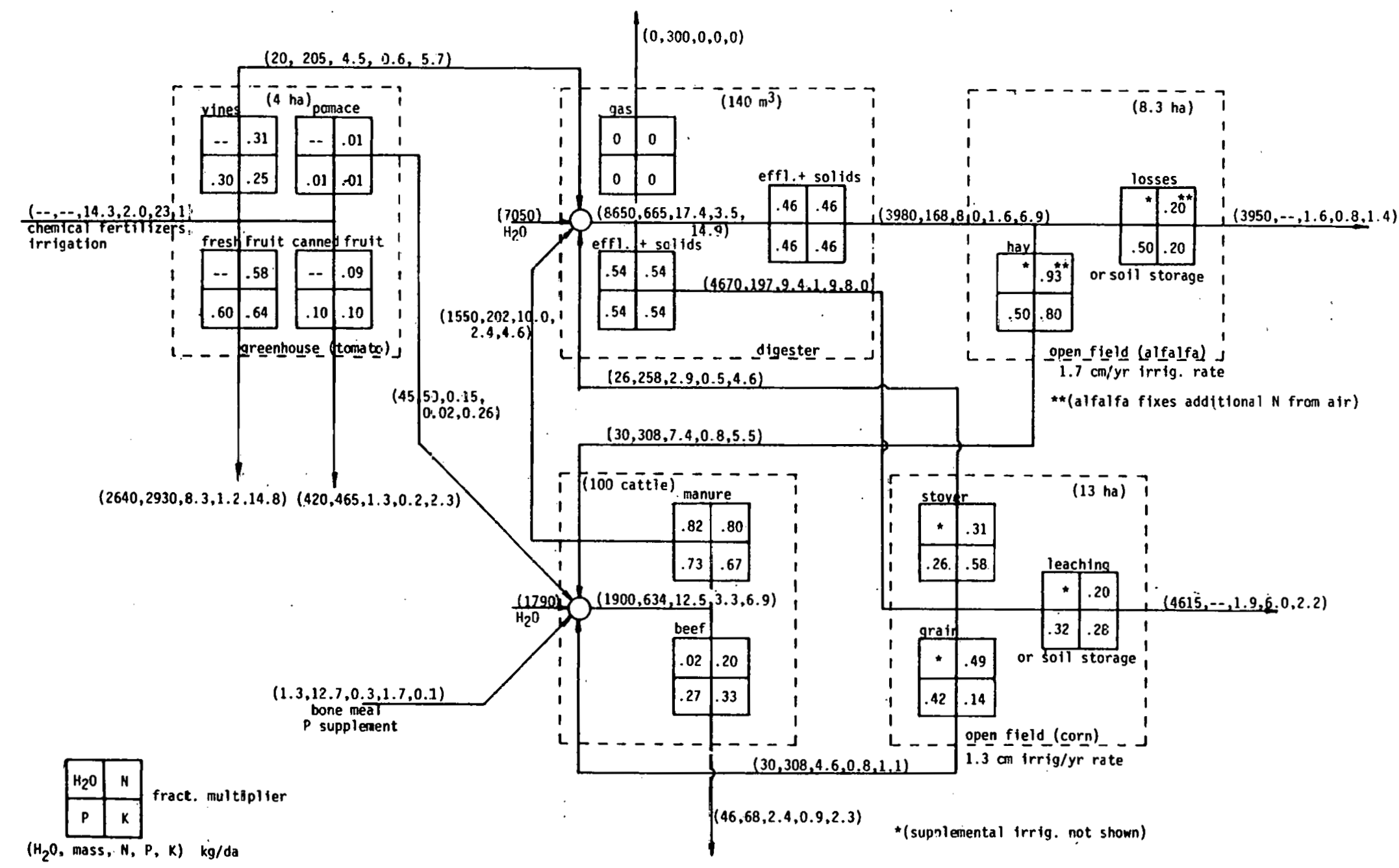

Figure E2. Integration of mass balances in the Greenhouse-Cattle-Digester-Open Field Complex. 


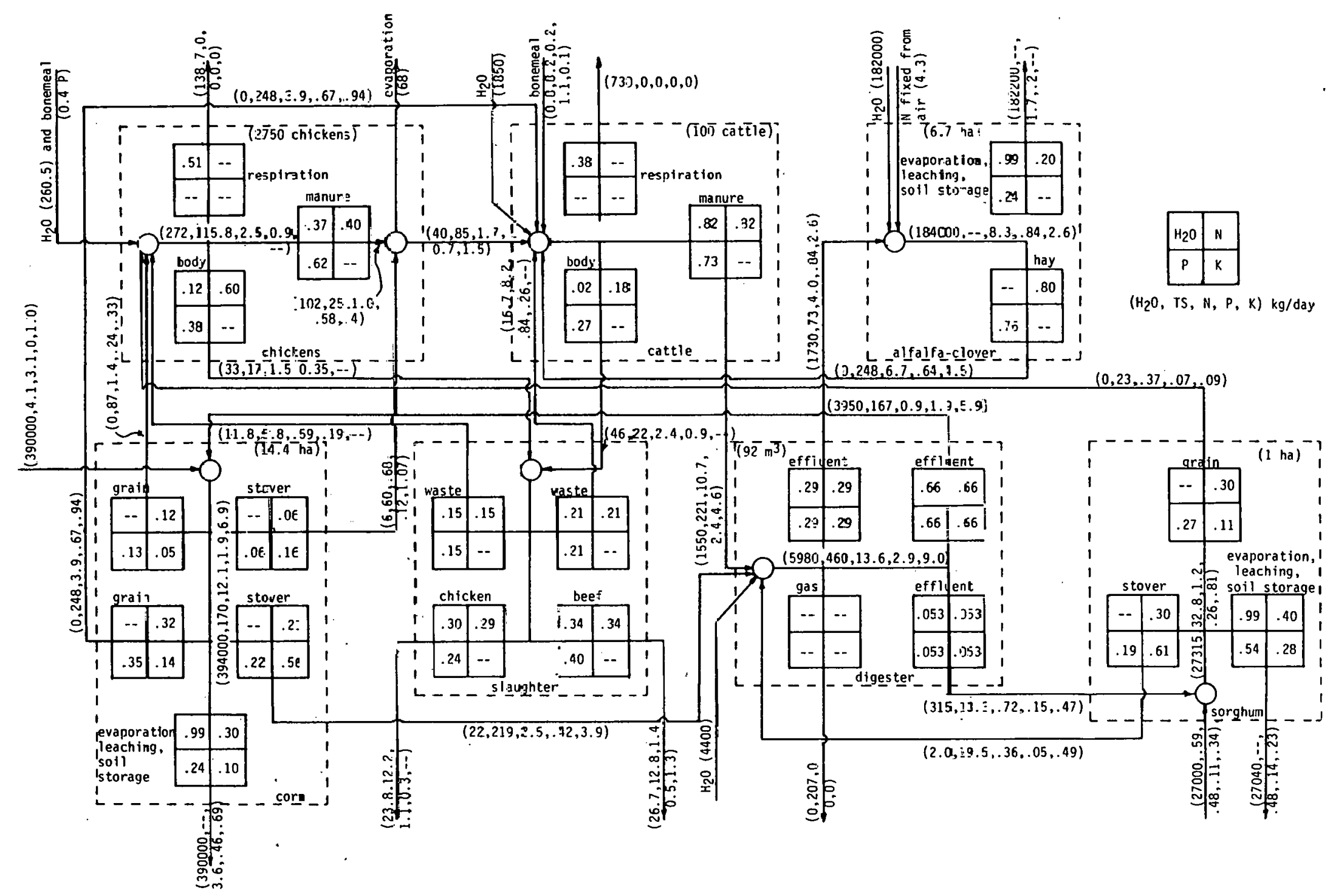

Figure E3. Integration of mass balances in the Chicken-Cattle-Digester-Open Field Complex. 


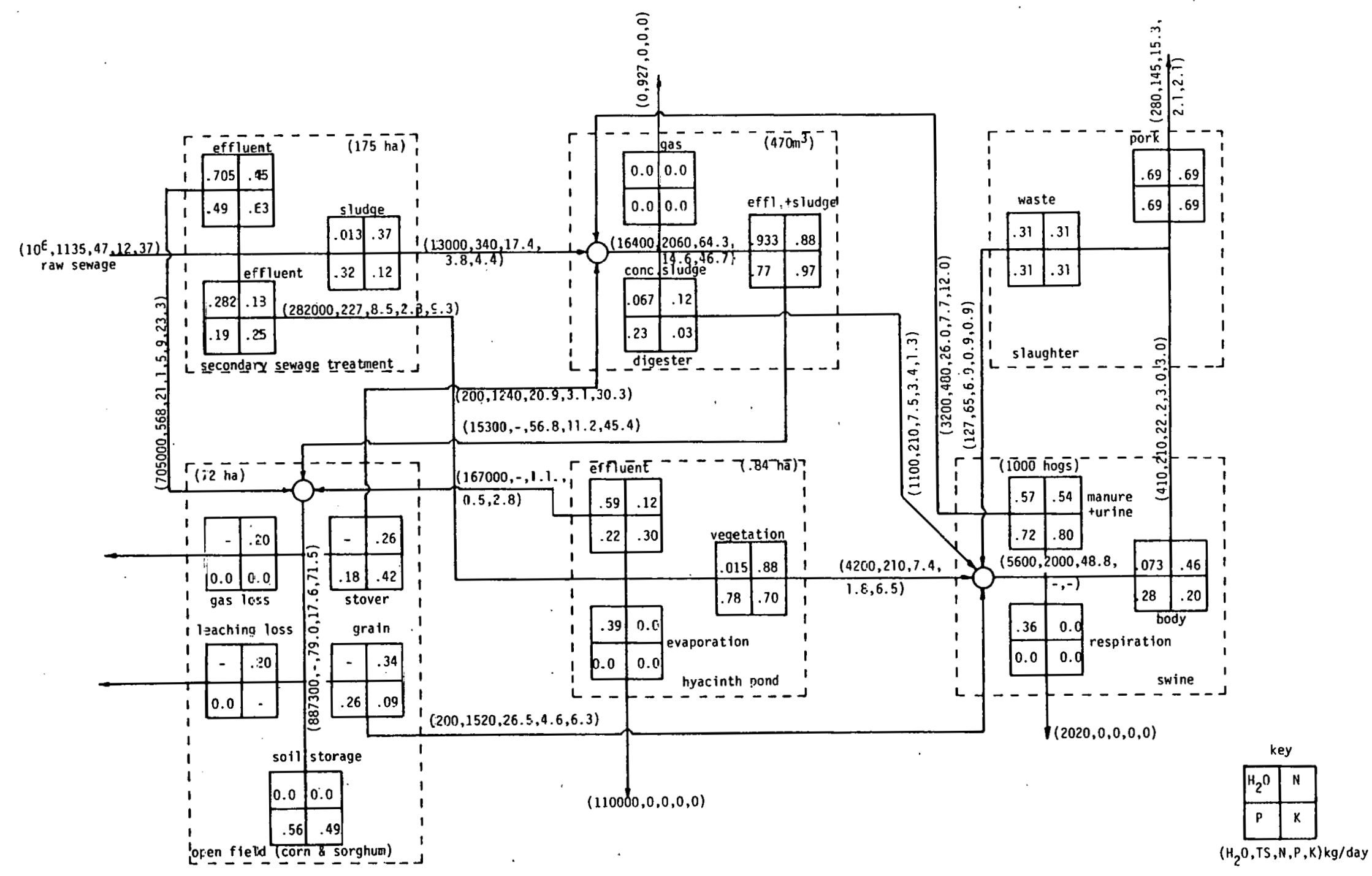

Figure E4. Integration of mass baiances in the Sewage-Digester-Hyacinth-Swine-Open Field Comples. 


\section{THIS PAGE}

\section{WAS INTENTIONALLY \\ LEFT BLANK}




\section{Internal Distribution}

$\begin{aligned} \text { 1. } & \text { T. D. Anderson } \\ 2 . & \text { S. Baron } \\ 3 . & \text { W. B. Cottrell } \\ \text { 4. } & \text { C. C. Coutant } \\ 5 . & \text { J. F. Harvey } \\ \text { 6. } & \text { R. F. Hibbs } \\ \text { 7. } & \text { H. W. Hoffman } \\ \text { 8. } & \text { D. Jarred } \\ 9 . & \text { M. Levenson } \\ \text { 10-100. } & \text { M. Olszewski } \\ 101 . & \text { H. Postma }\end{aligned}$

1. T. D. Anderson

aron

4. C. C. Coutant

7. H. W. Hoffman

8. D. Jarred

M. Olszewski

101. H. Postma

\author{
102-149. S. A. Reed \\ 150. Joe Rich \\ 151. M. W. Rosenthal \\ 152. M. J. Skinner \\ 153. I. Spiewak \\ 154. H. E. Trammell \\ 155. D. B. Trauger \\ 156-157. Central Research Library \\ 158. Document Reference Section \\ 159-160. Laboratory Records Department \\ 161. Laboratory Records, ORNL-RC
}

External Distribution

162-163. Director, Advanced Nuclear Systems and Projects Division, Nuclear Energy Programs, Department of Energy, Washington, DC 20545

164. Office of Assistant Manager, Energy Research and Development, Department of Energy, Oak Ridge Operations Office, Oak Ridge, TN 37830

165-169. Ira Helms, Department of Energy, Advanced Nuclear Systems and Projects Division, Washington, DC 20545

170. W. F. Savage, Department of Energy, Advanced Nuclear Systems and Projects Division, Washington, DC 20545

171. James G. Abert, National Center For Resource Recovery, 1211 Connecticut Avenue, NW, Wash1ngton, DC 20036

172. Sang Sun Ahn, Technical Officer, Air Pollution Control Division, Ministry of Health and Social Affairs, Seoul, Korea

173. Harvey Alter, National Center for Resource Kecovery, 1211 Connectlcut Aveluue, NW, Washington, DC 20036

174. A. M. Best, Sperry New Holland, New Holland, PA 17557

175. Max Blanchet, Pacific Gas and Electric Company, 245 Market Street, Room 1342, San Francisco, CA 94106

176. Larry Boersma, Department of Soils, Oregon State University, Corvallis, OR 97331

177. George Briggs, University of California, Natural Resource Department, 101 Giannini Hall, Berkeley, CA 94720

178. Edward Bryan, National Science Foundation, $1800 \mathrm{G}$ Street, NW, Washington, DC 20545

179. Charles M. Collins, Directur, Division of Public Health, Department of Health, GPO Box 5013, Wellington, New Zealand

180. Louis F. Diaz, President, Cal Recovery Systems, 160 Broadway, \#200, Richmond, CA 94804

181. Douglas Fiscus, Midwest Research Institute, 425 Volker Boulevard, Kansas C1ty, MO 64110 
182. Mufaulu T. Galuvao, Senior Health Inspector, Health Department, Apia, Western Samoa

183. Frank C. Go, Regional Advisor, WHO Regional office for the Western Pacific, P.0. Box 2932, Manila, Philippines

184. Jerome Goldstein, Editor, Compost Science/Land Utilization, P.0. Box 351, Emmaus, PA 18049

185. Rober Hodam, California Energy Resources Conservation and Development Commission, 11.11 Howe Avenue, Sacramento, CA 95825

186. Pablo R. Imperio, Supervising Sanitary Engineer II, Bureau of Health and Medical Services, Ministry of Health, Manila, Philippines

187. Rentaro Ito, Deputy Director, Food Sanitation Division, Environmenta1 Health Bureau, Ministry of Health and Welfare, Kasumigaseki, Chiyoda-ku, Tokyo 100, Japan

188. Robert Judd, Director, Office of Appropriate Technology, 1530 Tenth Street, Sacramento, CA 95814

1.89. Juseph Kel1ȳ, southern Cal Edisun Cumpany. P.O. Binx Rini, Kosemead, CA 91770

190. Lorie Larson, Southern Cal Edison Company, P.0. Box 800, Rosemead, CA 91770

191. Edwin W. Lee, Environmental Health Officer, WHO Regional Office for the Western Pacific, P.O. Box 2932, Manila, Philippines

192. T. F. Lye, Sanitary Engineer, c/o Dept. of Publi.s Health, P.0. Box 2084, Konedobu, Papua New Guinea

193. Car1 Madewe11, Nat. Fertilizer Development Center, Tennessee Valley Authority, Muscle Shoals, AL 35660

194. Alex Maralit, Programme Officer, UNICEF, Manila, Philippines

195. Honorable Imelda Marcos, Malacanang, Manila, Philippines

196. Charles R. McGowin, Electric Power Research Institute, P.0. Box 10412, Palo Alto, CA 94303

197. Alain Y. Morvan, United Nations Development Programme in the Philippines, P.0. Box 1864, Manila, Philippines

198. Wong Keng Mun, Hawkers Department, Princess House Annex, Alexandra Rnar, Singapore 3, Republic of Singapure

199. Metodin A. Palapay, Chairman, Taok Force for Melro Manlla, Environmental Sanitation, U.P. System, Diliman, Quezon City, Philippines

200. Ariel Parkinson, 1001 Cragmont, Berkeley, CA 94704

201. R. S. Pile, Agricultural Resources Development Branch, Tennessee Valley Authority, Muscle Shoals, AL 35660

202. Roy Rawani, The World Bank, $1818 \mathrm{H}$ Street, NW, Washington, IC 20433

203. Edward Remedios, Pacific Gas and Electric Company, 24.5 Market Street, Room 1342, San Francisco, CA 94106

204. Charlotte Rines, U.S. Department of Energy, Washington, DC 20545

205. Salvidor J. Rivera, Local Water Utilities Admin., 7 th Floor, NIA Building, National fnvernment Center, ESDA, Qucson bity 3004 , Philippines

206. Celson Rogue, Director, National Environmental Protection Council, Heart Center Bldg., East Avenue, Diliman, Quezon City, Philippines 
207. Juan Cruz Rosario, Jr., Environmental Health Administrator, Department of Public Health and Social Service, P.0. Box 2816, Agana, Guam 969610

208. Abdul Khalid bin Sahan, Director of Training and Manpower, Ministry of Health, 3rd Floor, MMA Building, Pahang Road, Kuala Lumpur, Malaysia

209. Mr. Saravanapavan, The World Bank, 1818 H Street, NW, Washington, DC 20433

210. A. Sekarajasekaran, Chief Public Health Engineer, Ministry of Health, Jalan Young, Kuala Lumpur 10-01, Malaysia

211. Neil Seldman, Institute for Local Self-Reliance, 1717 18th Street, NW, Washington, DC 20009

212. Han Soph Shim, Section Chief, Division of Food Hygiene, Ministry of Health and Social Affairs, Seoul, Korea

213. Nachea Siren, Exec. Officer, Division of Environmental Health, P.0. Box 71, Capitol Hill, Saipan, Mariana Islands 96050

214. Soll Conservation Society, 7515 N.E. Ankeny Road, Ankeny, I 50021

215. A. Sotelo, PAHO, Homero 418, Colonia Polanco, Mexico D.F., Mexico

216. Robert R. Stickney, Texas A\&M University, Dept. of Wildlife and Fisheries, College Station, TX 77843

217. Ernesto Terrado, Dept. of Energy, Merritt Road, Fort Bonifacio, Metro Manila, Philippines

218. G. J. Trezek, Department of Mechanical Engineering, University of California, Berkeley, Berkeley, CA 94720

219. John Vatehau, Senior Health Inspector, Ministry of Health, P.O. Box 349 , Honiara, Solomon Islands

220. Donald K. Walter, U.S. Department of Energy, Washington, DC 20545

221. Charles Weiss, Science and Technology Advisor (PAS), The World Bank, 1818 H Street, NW, Washington, DC 20433

222. Leonard Wohletz, 510 Vincente Avenue, Berkeley, CA 94707

223. S. T. Wolfgram, Senior Health Inspector, Ministry of Health, P.0. Box 209, Nuku'alofa, Tonga

224. Silas Zale, Environmental Sanitation, P.0. Box 2033 Yomba, Madang, Papua New Guinea

225-251. Technical Information Center, DOE, ORO 